The University of Maine

DigitalCommons@UMaine

Maine History Documents

Special Collections

1964

\title{
Historical Floods in New England
}

M. T. Thomson

William B. Gannon

M. P. Thomas

G. S. Hayes

Follow this and additional works at: https://digitalcommons.library.umaine.edu/mainehistory

Part of the History Commons, and the Other Earth Sciences Commons

This Report is brought to you for free and open access by DigitalCommons@UMaine. It has been accepted for inclusion in Maine History Documents by an authorized administrator of DigitalCommons@UMaine. For more information, please contact um.library.technical.services@maine.edu. 


\section{APR 201964}

\section{Historical Floods}

\section{in New England}

GEOLOGICAL SURVEY WATER-SUPPLY PAPER 1779-M

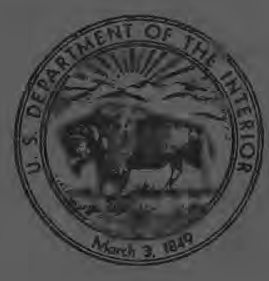




\section{Historical Floods}

in New England

By M. T. THOMSON, W. B. GANNON, M. P. THOMAS, G. S. HAYES, and others

CONTRIBUTIONS TO THE HYDROLOGY OF THE UNITED STATES

GEOLOGICAL SURVEY WATER-SUPPLY PAPER 1779-M

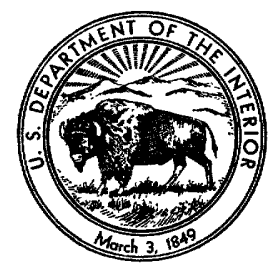




\section{UNITED STATES DEPARTMENT OF THE INTERIOR}

STEWART L. UDALL, Secretary

\section{GEOLOGIGAL SURVEY}

Thomas B. Nolan, Director 


\section{CONTENTS}

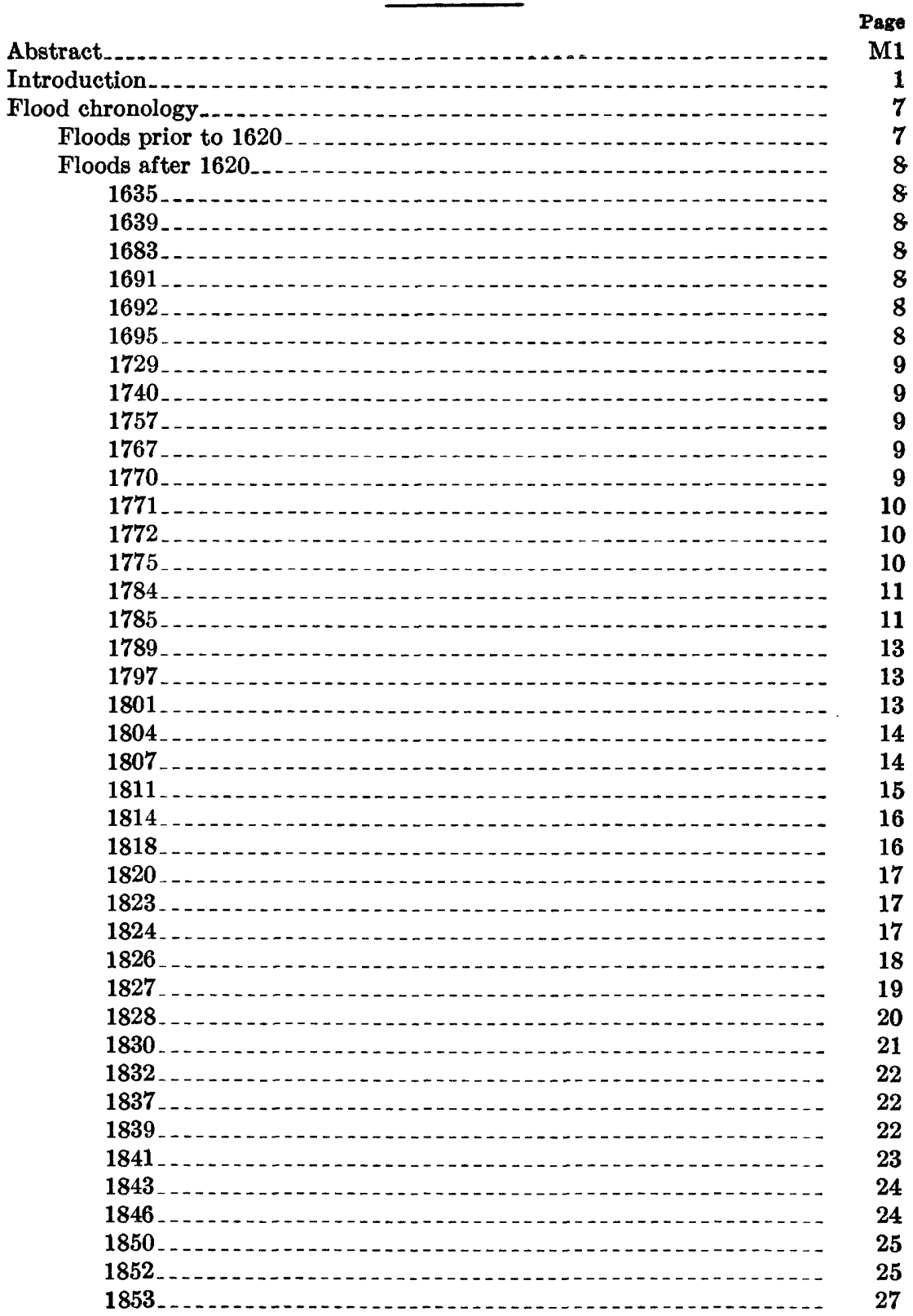


Flood chronology-Continued Floods after 1620-Continued

1854

$1855 \ldots \ldots \ldots$

1857

1859

1861

1862

1865

1866

1867

1868.

1869

1870

1874

1875

1876

1877

1878

1882

1886

1887

1891

1895

1896

1897

1900

1901

1905

1909

1913

1923

1924

1927

1928

1933

1936

1938

1953

1955 


\title{
CONTRIBUTIONS TO THE HYDROLOGY OF THE UNITED STATES
}

\section{HISTORICAL FLOODS IN NEW ENGLAND}

\author{
By M. T. Thomson, W. B. Gannon, M. P. Thomas, G. S. Hayes, \\ and others
}

\section{ABSTRACT}

One or more of the great recent New England floods of 1927, 1936, 1938, and 1955 exceeded the greatest known historical floods on most of the major rivers. Locally, on tributary streams, the great floods of recent years probably exceeded historical floods, but the certainty diminishes for the floods that occurred prior to the observance of living witnesses.

This report presents, by year, a condensation of the data on unusual historical floods (floods that occurred before establishment of gaging stations) and the sources of this evidence. This information will be helpful in the determination of the frequency of the highest flood or floods of record. Such determinations are necessary for studies of flood frequencies and magnitudes, which in turn are necessary for studies of relative costs and benefits of flood-control measures and of bridges, and for the evaluation of flood-plain insurance and zoning measures.

\section{INTRODUCTION}

Information on historical floods (those that occurred before establishment of gaging stations) differs from that on more recent floods in that the earlier information does not include explicit physical dimensions which gaging-station records supply for the recorded floods. The gaging-station record provides, at the specific site, the date and time of the flood, the height of the flood, its maximum discharge, the volume of water, the speed with which the flood waters collect and move downstream, and the rates of rise and fall of the water level. It also shows the effects of the channel configuration-both natural and manmade influences-such as ice jams, log jams, dams, levees, and detention reservoirs.

Of these many physical dimensions of a flood, only two can be expected to be available for historical floods-the date of occurrence and height of the water surface. The approximate date of the historical flood can usually be determined. Less often, the height of the flood may have been described. Only at a few localities are the heights of historical floods referred to fixed landmarks, such as the crest of a dam or to a gage. When this does occur, it is possible to compare these heights with the heights of other floods. 
The comparison of the magnitudes of historical floods with those of recorded floods depends mostly on two assumptions, both of which are akin to circumstantial evidence: First, that information concerning a given locality has comparative transfer value to another locality; and second, that witnesses of local floods made reliable observations of the relative magnitudes of the floods.

The first assumption rests on the dimensional information at dams, gages, and other permanent landmarks. If the landmark is permanent and the channel conditions are unchanged, the heights of historical floods may be compared to the heights of recorded floods, at that site. Flood heights alone, however, have limited transfer value when used to determine relative flood heights at other localities. If the flood height can be converted to flood discharge by means of flow determinations over dams or from current-meter measurements during the recent floods, the information has some transfer value.

Flood flow information can be transferred to other sites on the main stem of a major river by a number of acceptable techniques. The reliability of such transfers diminishes as the distance increases or as the disparity on size of the drainage area increases. Such transfers are fairly reliable for major floods but are less reliable for smaller floods.

The conversion of transferred discbarge information to water levels at other sites requires the definition of stage-discharge relationships at the other sites. These relationships can rarely be established for historical floods because of the uncertainty about channel conditions. For example, historical-flood heights in New England were frequently affected by ice jams or log jams, or were notable because bridges and dams were swept away. All these conditions may affect stage-discharge relations locally and temporarily. A relatively minor floodflow may cause unusual flood heights locally if the water is backed up by ice, logs, or debris. Frequently such jams cause severe changes in the channel itself.

The first assumption for comparing historical floods with recorded floods obviously has severe limitations.

The second assumption-that witnesses of local floods made accurate observations of relative flood magnitudes-also has severe limitations for it depends on the reliability of witnesses to flood events, and of the historians who record or interpret the observations of those witnesses. Historical-flood literature abounds in adjectives"awful," "great," "unusual," "calamitous," "devastating," "worst ever"-which have only vague dimensional status. The original witnesses varied in their reactions to floods. Some diarists and newspaper reporters mentioned floods frequently; others apparently mentioned them but rarely. Some witnesses became excited over 
floods; others reported them calmly. The variety of accounts of floods in the early town histories reflects the interests of the historians and original reporters as well as the significance of the flood events themselves.

Even when a witness reported a bridge swept away by a flood, he rarely gave a usable dimension of the flood itself. The bridge might have failed during a minor flood owing to undermining of its piers, or during a major flood that continued to rise long after the structure was overtopped.

The second assumption is just as obviously even more tenuous than the first one.

What then may be gained by a study of historical floods? Certainly, little information about the physical dimensions can be obtained. However, such a study does provide valuable knowledge about the frequency dimensions, which is subject to appraisal in terms of statistical probabilities.

The number of years for which flood dimensions are known is highly significant. Because confidence in the prediction for the future depends very much on the length of the actual experience of the past, a very long record of flood events, even though partly qualitative, is much more desirable than a short record of accurate flood data.

Keeping of systematic flood records for the major New England rivers, began about 1904 . Yet, it is fairly certain that the recent floods exceeded all historical floods back to the date of white settlement-some 200 to 300 years ago. Even though the magnitudes of the early floods cannot now be determined, the fact that there is no historical evidence that they were as high as the great recent floods is valuable. The historical-flood study shows, in effect, that the maximum flood of record is the maximum flood since the date of settlement, on the grounds that no evidence to the contrary has been found by a thorough search. The student of flood frequencies has much more to work with if he knows that a flood is the highest in 200 to 300 years than if his knowledge is limited to data covering only 55 years or so.

The historical flood information would have little merit if it rested merely on the casual statement of a local historian, on the unsupported belief of one hydraulic engineer, or on isolated and scattered bits of evidence. However, when hydrologic specialists have made a thorough search of historical literature concerning most of New England, interviewed hundreds of eyewitnesses at hundreds of localities, and compiled and studied this mass of evidence, a high degree of confidence in the conclusions becomes warranted.

The investigation of historical floods was a preliminary step in the study of flood frequencies and magnitudes in New England. It had 
been generally believed that one or more of the great floods of 1927 , 1936, 1938, and 1955 exceeded all floods prior to those dates in much of New England, but no intensive investigation of historical floods for the entire area had been made to confirm that belief.

Consequently the investigation was organized, in 1957, to collect documentary evidence of the magnitude of historical floods. A historical flood was defined as one that occurred prior to the establishment of gaging stations. Local authorities were interviewed concerning the relative magnitude of the historical floods with respect to the more recent great floods for which gaging-station records are available.

The search for historical-flood information began in July 1957. The localities to be included were selected if they had experienced at least one great flood within the period of gaging-station record and if there were no known manmade changes that would seriously impair comparisons of historical floods with the floods of known magnitude. Fieldwork was intensive until the end of October 1957, and some work continued intermittently into the autumn of 1958. Investigation in the western part of Vermont that drains into the St. Lawrence River basin was limited because of the widespread evidence already at hand which showed conclusively that the flood of 1927 greatly exceeded any historical flood in that area.

The search for historical-flood information began with a review of the gaging-station files of the U.S. Geological Survey and of the published flood reports by the Geological Survey and others. Historical-flood data and reference to sources were abstracted. A general. library search was then conducted.

In the library search the larger State and city libraries, historical and genealogical society collections, and the files of the older newspapers were examined to record the date of every notable flood event.

After a list of known flood events had been compiled, the engineers conducted field interviews in the selected localities. The field interviews generally led to elderly people who had vivid and quite accurate memories of events in their childhood. Their observations frequently established the fact that recent floods were the highest since about 1875. However, the engineers were interested in still earlier events, for which there were no longer eyewitnesses. The inquiries were then directed to finding landmarks which pertained to historical floods and which were mentioned in historical documents.

The investigators found disappointingly few landmarks which might have represented definite levels reached by historical floods. Except at localities like Hartford on the Connecticut River and Pawtucket Dam on the Merrimack River, where flood levels continue to cause concern, few comparative floodmarks for the early historical 
floods were found. Three factors explain this lack of historical floodmarks. First, floods in the spring breakups in New England were so common that people generally took them for granted and no one thought enough of them to set marks to preserve a record of their height. Second, the terrific flood events of recent times caused so much damage that whole areas were ravished by the flood waters, and landmarks close to the streams either were destroyed or the channel and flood-plain conditions were so changed that the old marks became meaningless. Third, many of the small mills, which depended on the rivers for their power, failed in the disastrous 1930's because of flood damage or the severe economic depression. The old firms, when they sold out, removed their records to places unknown to the new proprietors or to places too far removed for the investigators to attempt to find them.

The accumulation of historical-flood information from written sources and local interviews led in most cases to the conviction that one or several of the great floods since 1927 were indeed the highest that had occurred since white men first came to the area. In some instances the period of positive conclusions had to be limited to the lifetime of living witnesses, in others, the period could be extended back to the known date of a general great flood, the local magnitude of which could not be identified; in still others, it was appropriate to limit positive conclusions to a certain date, and extend qualified conclusions back to the date of settlement.

The investigation yielded a wide variety of information. In sparsely settled regions, such as some parts of northern Maine, relatively little information was found. In densely settled regions, particularly where the flood plains are occupied by mills and residences, an abundance of information was found. Likewise, the information available varied with the social and economic effects of floods. In areas where floods cause little damage, little or no information was available; but where flood damage is great, there was a surfeit of information. In general, the information was more explicit and more plentiful for areas near the mouths and along the main stems of the larger rivers. The information diminishes as the streams become smaller.

One critical element in the investigation was the determination by the engineer of the relative stability of channel conditions. Obviously, flood heights would have little significance if major changes had taken place in the channel or in the river basin. For example, the engineer took considerable pains to learn if dams existed during the historical flood events or if they had been built or enlarged between Hloods. Reliable observations of historical and recent flood heights 
at the same locality occasionally were useless for comparative purposes because dams had been built or washed out.

Encroachments on the river channels or flood plains by bridges, buildings, or levees had the same general effect as dams, and were taken into account in reaching conclusions.

Another consideration was the presence of large detention reservoirs in the drainage basins. The recent construction of floodcontrol reservoirs has altered the regimen of floods in the valleys downstream. The areas seriously affected were not investigated.

Another river-basin condition that the engineers had to evaluate was the effect of dam failures during floods. The local reports often attributed much of the flood to dam failures. Many such failures, however, had little effect downstream because the amount of extra flood water released was a small part of the natural flood water. Considerable doubt sometimes exists as to the part played by the dam failures; however, the dam failures occasionally were dominant factors in the severity of the flood downstream.

Upon the completion of the library and field search, each engineer summarized the information for the gaging stations and river basins assigned to him and reported his conclusions to the Research Section, Surface Water Branch, of the Geological Survey. The Research Section then used the individual-station data for studies of flood frequencies and magnitudes.

The information collected during the investigation has been condensed in this report into a chronological arrangement of flood information and an index by stream names giving the flood years. The listing of information for each event in the chronological accounts follows in general the downstream order used by the Geological Survey in its surface-water reports.

In order to condense the great volume of information collected to. workable proportions, the authors have omitted references to obviously minor flood events. They have merely reported the time, place, and source of information for floods which may have been large enough to be considered in frequency-magnitude studies but for which no real evidence of magnitude was found. They have reported only the parts of the descriptions of major floods that give some evidence of the magnitude of the flood. In general, they have selected the most objective source of information when several sources are available and have not given duplicate sources unless the several sources. contain supplemental information.

The library and field investigations were under the general supervision of M. T. Thomson; he was assisted by personnel of the three surface-water districts of the Geological Survey in New England. Thomson made the investigation of the Merrimack River basin. 
W. B. Gannon, under the direction of C. E. Knox, district engineer of the Boston district, made the investigation of the coastal river basins of Massachusetts and Rhode Island and the Connecticut River basin above Connecticut. M. P. Thomas, under the direction of B. L. Bigwood, district engineer of the Hartford district, made the investigation of the lower Connecticut River basin and of the coastal river basins of Connecticut. Mr. Thomas was assisted by E. L. Burke and M. B. Stackpole. G. S. Hayes, district engineer of the Augusta district, made the investigation of the river basins in Maine, assisted by R. A. Morrill. General direction of the investigation was by Tate Dalrymple, chief of the Floods Section, and R. W. Carter, chief of the Research Section of the U.S. Geological Survey.

Flood data for gaging stations in the area have been summarized in Geological Survey Water-Supply Paper 1301, "Compilation of Records of Surface Waters of the United States through September 1950." Subsequent flood data appear in part 1A of the annual Surface Water-Supply Papers. In general, these data are not reproduced in this report unless it is felt that inclusion of records of stage or discharge at a specific site permits determination of the relative stage or discharge of a historical flood.

Those reports describe the methods by which flood data are obtained and acknowledge the cooperation of others who have assisted in the collection of the data.

\section{FLOOD CHRONOLOGY}

\section{FLOODS PRIOR TO 1620}

Only one reference was found concerning floods prior to the coming of the English to New England in 1620. This reference appears in John Josselyn's "An Account of Two Voyages to New England," first published in 1674 and quoted by the Federal Writers Project 1938, p. 28:

Ask them [the Indians] whither they go when they dye, they will tell you pointing with their finger to Heaven beyond the white mountains, and do hint at Noah's Floud, as may be conceived by a story they have received from Father to Son, time out of mind, that a great while agon their Countrey was drowned, and all the People and other Creatures in it, only one Powaw and his Webb foreseeing the Floud fled to the white mountains carrying a hare along with them and so escaped; after a while the Powaw sent the Hare away, who not returning emboldned thereby they decended, and lived many years after, and had many Children, from whom the Countrie was filled again with Indians.

The account is so purely legendary that it has no value in extending the knowledge of historical floods back beyond the dates of English settlement. 
FLOODS AFTER 1620

1635

NEW GNGLAND COAST (AUGUST 15)

A great storm "desolated the coast" (Burrage, 1914, p. 250254).

The tide rose to " $a$ height unknown before." At Boston it measured 20 feet. "Governor Bradford, who was a witness to the tempest, said that none then living, either English or Indian, ever saw a storm to equal it" (Perley, 1891, p. 3-10).

LOWER CONNECTICUT RIVER VALLEY (AUGUST)

"*** flood and hurricane denuded the river valley.

the terrible flood washed away and buried the corn crops" (Hard, 1947, p. 265).

\section{9}

CONNECTICUT RIVER AT WINDSOR, CONN. (MARCH 17, 18)

"**** the great flood ***. It indamaged houses and break down many trees, so that by the cause of which rain all the 17 th and 18th days the water rose very high, more than had ever before been known by the Indians" (quoted from Mathew Grant in Kinnison and others, 1938, p. 2-3).

\section{3}

CONNECTICUT RIVER AT HARTFORD, CONN. (JULY OR AUGUST)

A flood reached a stage of what would be 26.0 feet on the present (1957) gage (Kinnison and others, 1938, p. 16).

\section{1}

NAUGATUCK RIVER IN CONNECTICUT (FEBRUART)

"Great Flood, so called. * * * the river left its banks and covered the meadows, rising to a height never before known, before or since. *** Great damage was done to the river lands ***. Discouraged, many forsook the place in dispair" (Bronson, 1858, p. 111).

1692

CONNECTICUT RIVER AT HARTTORD, CONN. (FEBRUARY)

For relative flood stages, refer to page 85, this paper. Floods drowned livestock in the meadows, carried away bridges, mills, houses, and "ye very land with ye English graine sown on it" (Hammond, 1892).

WESTFIELD RIVER IN MASSACHUSETTS (DATE UNKNOWN)

"A great flood which formed the town island" (Maschin, 1955).

\section{5}

CONNECTICUT RIVER IN LONGMEADOW, MASS. (DECEMBER)

A "mighty" flood covered the lowlands, invaded the floors of houses, and "still it rose." Inhabitants fled to hillsides and to Springfield (Johnson, Clifton, 1936, p. 884). 
1729

QUINEBAdG RIVER at CANTERBURY, CONN. (FEBRUART 28)

"**** a good cart-bridge twenty seven feet high from the bottom of said river-which is four feet higher than any flood known these thirty years- $* * *$ built in 1728 , was soon swept away by a freshet" (Bayles, 1889, p. 441, 497).

SHETUCKET RIVER AT NORWICH, CONN. (FEBRUARY 28)

“*** extraordinary flood $* * *$. The ware houses at the

Landing were much injured" (Norwich Bulletin, Feb. 14, 1886).

1740

MERRIMACK RIVER AT MANCHESTER, N.H. (DECEMBER)

"The river rose to a fearful height and overflowed the banks

below the falls" (Browne, 1915, p. 173).

MERRIMACK RIVER NEAR MOUTH IN MASSACHUSETTS (DECEMBER)

"The snow melted, and a freshet occurred in the Merrimack river, nothing like it having been experienced there for seventy years. At Haverhill, the stream rose fifteen feet, and many houses were floated off" (Perley, 1891, p. 49-51).

1757

QUINEBaUg river at pUtNaM, CoNn. (FEBRUARY)

"In the severe freshet of 1757, Jabez Fitch's bridge was partially destroyed" (Bayles, 1889, p. 497).

SHETUCKET RIVER AT NORWICH, CONN. (FEBRUARY)

"In 1757, a severe flood worked havoc with bridges and buildings" (Norwich Bulletin, Feb. 14, 1886).

1767

PISCATAQUOG RIVER IN NEW HAMPSHIRE (DATE UNKNOWN)

A bridge built in 1766 was carried away (Hadley, 1922, p. 217). QUINEBAUG RIVER IN CONNECTICUT (DATE UNKNOWN)

Bridge again swept away by freshet (Bayles, 1889, p. 443).

CONNECTICUT RIVER AT HARTFORD, CONN. (JANUARY)

"Great and sudden flood *** much damage along the Connecticut Valley. Streams rose to prodigious heights, carrying bridges, mills, dams, and damaging buildings and dwellings" (notes by Mr. W. W. Neifert concerning floods on the Connecticut River at Hartford, Conn.; in the U.S. Weather Bureau office in Hartford, Conn.

1770

KENNEBEC AND ANDROSCOGGIN RIVERS IN MAINE (JANUARY)

“*** loss of many mills and dams $* * *$ owing particularly to heavy ice going out"' (Kinnison, 1929, p. 85).

"*** in the Androscoggin River, the freshet was most destructive. At the Brunswick Falls, all of the mills *** were entirely destroyed, the monstrous dam at the falls also being partly carried away. $* * *$ ice along its banks below the falls sixty feet high" (Perley, 1891, p. 81). 
PISCATAQUA AND PISCATAqUOG RIVERS IN MAINE AND NEW HAMPSHIRE (JANUARY)

"* * * remarkable inundation carried away mills and bridges"

(Belknap, 1792, p. 52, 67).

MERRIMACK RIVER IN NEW HAMPSHIRE (JANUARY)

"Severe rainstorms * * * caused great floods * * *" (Browne, 1915 , p. 173).

PAWTUXET AND OTHER RIVERS IN RHODE ISLAND (JANUART)

“*** a great flood *** many Mills, Bridges, etc., carried

away. * * * Rivers higher than they have been known these 30 years, some say 50 . The quantity of rain was great, being 3 inches and \%/10" (Providence Gazette, Jan. 13, 1770).

CONNECTICUT RIVER AT BRATTLEBORO, VT. (DATE UNKNOWN)

"*** * island opposite this village was under water in 1770

***" (Cabot, 1922, p. 822).

CONNECTICUT AND FARMINGTON RIVERS IN CONNECTICUT (JANUARY)

"For fifteen years the Connecticut river had not risen so high.

* * * Farmington river * * * at Simsbury, the buldings at the iron works of Richard Smith * * * was entirely destroyed" (Perley, 1891, p. 78-82).

1771

NATCHAUG, WILLIMANTIC, SHETUCKET RIVERS IN CONNECTICUT (SPRING)

"An extraordinary flood and great accumulation of ice in 1771 demolished and carried away nearly every bridge in the whole county * * *' (Bayles, 1889, p. 276).

CONNECTICUT RIVER IN COOS AND GRAFTON COUNTIES, NEW HAMPSHIRE (AUTUMN)

Great freshet buried some fields "2 or 3 feet with sand"-said to be "the greatest, perhaps, on the Connecticut River" (Benton, 1886 , p. 113 ; Waite, 1895 , p. 382).

1772

FARMINGTON AND SHETUCKET RIVERS IN CONNECTICUT (FEBRUARY 21)

"6* * bridges swept away by the late flood at Windsor, Poquonnock, Simsbury, and Farmington, greatest Freshet at Norwich Landing that has been known for 30 Years past, on the Shetucket River" (Connecticut Courant, Mar. 3, 1772).

1775

SACO RIVER IN NEW HAMPSHIRE (OCTOBER)

"* * * the great flood * * * when a large stream called New River, broke out of the White Mountains and bore down everything in its way. The Saco River, being swelled enormously by the accession to its waters, swept away mills, bridges, domestic animals, and great quantities of lumber" (Williamson, 1839, p. 29).

CONTOOCOOK RIVER IN NEW HAMPSHIRT (DATE UNKNOWN)

One of the five highest "freshets" on the Contoocook River (Lord, 1890, p. 282). 
1784

PAWCATUCK RIVER AT WESTERLT, R.I. (JANUART)

"The 1784 flood was 1 foot lower than the flood in 1886 at Westerly" (Westerly Sun, Mar. 17, 1953).

SHETUCKET RIVER BASIN IN CONNECTICUT (JANUARY)

"The greatest flood in the Little river * * * that has been known this 64 years, and but few people now living ever saw a greater flood in the river Shetucket that now runs there" (Connecticut Courant, Jan. 13, 1784).

"On Jan. 8, 1784 a greater freshet affected both the Yantic and Shetucket, but as the Thames was open, Norwich was not inundated" (Norwich Bulletin, Feb. 14, 1886).

piscataquog RIVER at piscataqUog, N.H. (DECEMBer 5)

"Great freshet. Bridge at Piscataquog carried away" (Hadley, 1922, p. 554).

MERRIMACK RIVER IN NEW HAMPSHIRE (DATE UNKNOWN)

“* * * A tradition, somewhat vague, speaks of a very high freshet in 1784" (Walker, 1896, p. 14).

1785

"A considerable amount of rain fell in the month of September, 1785 , and from time to time during October it continued to fall in unusual quantities until Thursday, the twentieth. [From the twentieth to the twenty-second] the rain steadily fell in extraordinary quantities. $* * *$ nine inches of water [fell] during the three days. It fell principally on southeastern New Hampshire and the adjoining country * * *" (Perley, 1891, p. 117-120).

SANDY RIVER AT FARMINGTON FALLS, MAINE (OCTOBER)

For relative flood stages, refer to page 75 , this paper.

ANDROSCOGGIN RIVER AT BETHEL, MAINE (OCTOBER 22)

“* * * the highest stage ever known, 25 feet above the normal.

Investigations during 1936 indicate ***1.5 feet higher than that of March, 1936. Log jams may have affected the stage of the flood in 1785" (Grover, 1937, p. 445).

SACO RIVER IN MAINE (OCTOBER)

"The Saco River probably rose higher than the other streams in that region. ${ }^{*} *$ never been known to rise so high before * * *" (Perley, 1891, p. 117-120).

"Both spans of the bridge between Saco and Biddeford, Maine, were carried away, also many bridges, houses, and mills in the upper reaches" (Grover, 1937, p. 447).

KENNEBUNK AND MOUSAM RIVERS IN MAINE (OCTOBER)

" 'Calamity' at Kennebunk *** mills, the bridge, and nearly every other structure swept away ***" (Perley, 1891, p. 117120). 
PISCATA QUA RIVER IN MAINE (OCTOBER)

"On the Salmon Falls branch * * * the banks were overflowed and the houses of Squire Lord and a Mr. Marshall were filled with water to a depth of 4 or 5 feet. Every bridge on the river was carried away ***" (Perley, 1891, p. 117-120).

COCHECO RIVER IN NEW HAMPSHIRE (OCTOBER)

"No other freshet in that river has been known to equal this" Perley, 1891, p. 117-120). "Below the great fall, the water rose 14 feet above the high water mark" (Belknap, 1792, p. 52).

BAKER RIVER NEAR WENTWORTH, N.H. (OCTOBER)

"The first bridge across Baker's River was carried away by high water in 1785" (Plummer, 1930, p. 314).

PEMIGEWASSET RIVER BELOW BAKER RIVER (OCTOBER 23)

"A record made by the Town Clerk at Newchester said that the water was about 30 feet above the bed of the river" (Musgrove, 1904, p. 472).

CONTOOCOOK RIVER IN NEW HAMPSHIRE (OCTOBER)

Greater than the floods of 1775; August, 1826; April, 1852; and April, 1870 (Concord Monitor, June 18, 1883).

MERRIMACK RIVER NEAR CONCORD, N.H. (OCTOBER)

"*** Henry Gerrish, the son of Col. Henry Gerrish who was the first settler on what is now the Merrimack County Farm $* * *$ mentioned the great freshet, and said there had never been anything like it since. $* * * \mathrm{I}$ asked Mr. Gerrish how much higher this freshet was compared with others. He said fully 12 feet, and that it covered all the land on the opposite side of the river several feet deep, and the high ridges of land east of the [Boscowen] depot were all under water. The whole valley of the Merrimack was a flood of water (Concord Monitor, June 18, 1885).

MERRIMACK RIVER BELOW MANCHESTER, N.H. (OCTOBER 24)

"The river at the height about 10 of the clock, the highest even known" (Patten, 1903).

"The greatest freshet in Merrimack River of which there is any record or tradition was in October, 1785" (Francis, 1885).

MERRIMACK RIVER AT TYNGSBORO, MASS. (OCTOBER 24)

“* * * higher than it was ever known before," from the memorandum book of John Parkham (Francis, 1885).

MERRIMACK RIVER AT PAWTUCKET FALIS, LOWELL, MASS. (OCTOBER 24)

"I think it certain, however, that the quantity of water flowing in the river was somewhat greater in 1785 , as the height at Nashua was about 2 feet higher in 1785 than in 1852 as I ascertained by inquiry in 1852. The extra height in the latter year at Lowell, if any, can be fully accounted for by the obstruction 
[masonry bridge below dam] which did not exist in 1785" (Francis, 1885).

An undated and unsigned tabulation of maximum discharges of the Merrimack River at Lowell, Mass., prepared for the American Society of Civil Engineers shows the following data (discharge in cubic feet per second):

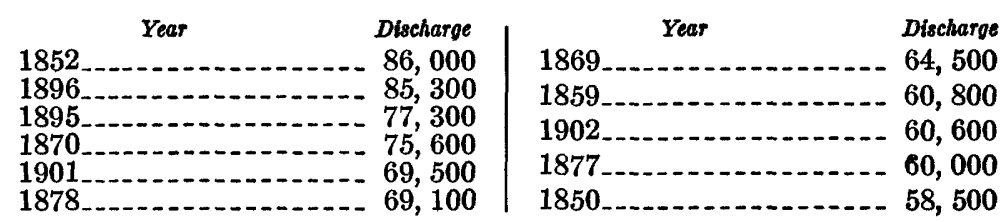

To this list had been added "October 24, 1785, plus or minus, $90,000 * * *$ based on levels of 1836 on high water marks pointed out by various people who had observed this freshet. This 1785 freshet was the highest that had occurred within the memory of people then living or since, about 1735." (Flood files of the Proprietors of the Locks and Canals on the Merrimack River, Lowell, Mass.)

1789

SHETUCKET AND YANTTC RIVERS IN CONNECTICUT (JUNE)

“*** that Shetucket River was, at Windham, three, and at Norwich Landing, four feet higher than it has been for 80 years past" (Connecticut Courant, June 22, 1789).

For comparative flood stages, see page 48, this paper.

1797

CONNECTICUT RIVER NEAR NORTH WALPOLE, N.H. (DATE UNKNOWN)

"While the canal was in progress of construction at Bellows Falls, in 1797 a flood occurred the effects of which are beneficial in that it changed the land considerably where the mills have since been located 'under the hill' east of the canal ***' (Hayes, 1907, p. 393).

For comparative flood heights, see page 17.

\section{1}

SHETUCKET, QUINEBAUG, AND WILLIMANTIC RIVERS IN CONNECTCUT (MARCB)

"The new bridge built last summer over the Shetucket $* * *$ and which was supposed to be proof against floods and ice, yielded to the impetuosity of this freshet $* * *$. A small bridge over the Willimantic in Coventry $* * *$ was also carried off. The Quinebaug, we understand, was likewise very high * * *" (Connecticut Courant, March 30, 1801).

CONNECTICUT RIVER IN MASSACHUSETTS AND CONNECTICUT (MARCH 20)

For relative flood stages, refer to page 85 . 
"In this town, there is no mark of so high a flood in Connecticut River, since the year 1692" (Connecticut Courant, March 23, 1801).

FARMINGTON RIVER IN CONNECTICUT (MARCH)

"The damage above on this river $* * *$ is much more than all before this from the first settlement of this country" (Connecticut Courant, March 23, 1801).

“*** the Jefferson flood $* * *$ far surpassed anything of the kind within the memory of any of the Fathers, and most of the high water marks yet remain unsurpassed for the last fifty-five years" (Brown, Abiel, 1856, p. 147).

"The principal bridges at Farmington are gone, their oldest people acknowledge that the water rose four feet higher than at any time within their memory" (Litchfield Monitor, March 25, 1801).

For comparative flood heights at Simsbury, Conn., see page 30 . NAUGATUCK RIVER AT WATERBURY, CONN. (MARCH)

“* * * the flood was greater than has been known for 40 years" (Litchfield Monitor, March 25, 1801).

For comparative flood information, see page 28.

HOUSATONIC RIVER NEAR BRIDGEPORT, CONN. (MARCH)

"The rivers and brooks were raised to a height hardly ever known before, and the damage $*^{*} *$ is incalculable" (Connecticut Courant, March 30, 1801).

\section{4}

FARMINGTON RIVER IN CONNECTICUT (DATE UNKNOWN)

The forge on the east bank of the Farmington River that was damaged in the flood of 1801 "was swept off by the great flood of 1804" which probably came as a result of the melting of deep snow, though details are lacking (Brown, Abiel, 1856, p. 79, 147).

1807

PENOBSCOT RIVER IN MAINE (FEBRUARY 17)

"An ice jam formed below Bangor Village raising the water 10 to 12 feet higher than was known before" (Williamson, 1839, p. 70).

MERRIMACK RIVER AT LAWRENCE, MASS. (FEBRUART)

"A winter flood, reaching every river in New England, occurred in February, 1807 when a great bridge over the Merrimack River at Lawrence, Mass., was washed away" (Browne, 1915, p. 174). CHARLES RIVER IN MASSACHUSETTS (FEBRUARY)

"6*** There was a great freshet in the river following a thirty-six hour rain. Many mill dams and bridges were carried away, among them the Boies dam at Waltham. ***The Boies Dam was built built in 1788" (Sanderson, 1936). 
NEPONSET RIVER IN MASSACHUSETTS (DATE UNKNOWN)

"The waters rose until they ran a foot deep over the Stetson dam and threatened to destroy it" (DeLue, 1925, p. 274).

SHETUCKET RIVER AT NORWICH, CONN. (FEBRUARY)

“*** a scene never before witnessed by the oldest inhabitants $* * *$. The Shetucket rose 30 feet -6 or 8 feet higher than the freshet of June 1789" (Evening Courier, Feb. 18, 1807).

“*** The Shetucket River rose from eighteen to twenty feet, and at Norwich the stream could not contain the water that came down. $* * *$ The water rose in the houses until it reached the first stories, and compelled the inmates to go into their chambers to escape the flood $* * *$. The water [rose] *** until it was within a few inches of the chamber floors ***. The flood extended from East Main to Franklin streets, and from hill to hill ***' (Perley, 1891, p. 176).

For comparative flood heights, see page 48.

QUINEBAUG RIVER IN CONNECTICUT (DATE UNKNOWN)

"The great flood of 1807 damaged Butts Bridge" (Bayles, 1889 , p. 497).

SCANTIC RIVER IN CONNECTICUT (DATE UNKNOWN)

"The Scantic River took out nearly all the mills on the river" (American Mercury, Feb. 12, 1807).

QUNNIPIAC RIVER IN CONNECTICUT (FEBRUARY)

"New Haven, Feb. 3.- On Saturday and Sunday evening last, a remarkable quantity of rain fell in this quarter of the State. As the earth was frozen firm by the late severe frost, none of it was absorbed ***." Many bridges and mills destroyed (American Mercury, Feb. 12, 1807).

"Feb. 17, 1807.-Another Flood-On Friday evening last, the 13th, commenced a second storm or rain. $* * *$ the bridge over the Little River which withstood the former shock was destroyed and so also is what was left of Dragon bridge. Within the city the damage done is very considerable and much greater than was ever occasioned by any former flood" (Connecticut Herald, New Haven, Conn.).

HOUSATONIC RIVER IN CONNECTICUT (FEBRUARY)

“*** Entire destruction of the fine bridge over the Housatonic, called Washington bridge ***.

"Bridges at Derby gone. Indeed, such havoc was never known before in this part of the country" (American Mercury, Feb. 12, 1807).

1811

OTTAUQUECHEE RIVER AT WOODSTOCK, VT. (JULY 22)

"But by far the most memorable of all floods in this vicinity took place on the 22nd of July, 1811. The storm that attended 
it exceeded in violence anything of the kind ever known in these parts $* * *$.

"Capt. Phinehas Williams, who in 1811 had been living on the Quechee 37 years, remarked of the flood then occurring that he had never known the river so high but once before. He gave no date, but reasoning from facts we may place the flood he alluded to in 1790 or 1791" (from a notebook of newspaper clippings in the Woodstock library).

SANDT RIVER IN MAINE (MAT)

"*** * the 1814 flood carried away a portion of the bridge at Falls Village which had been built in 1808" (Butler, 1885, p. 260). ANDBOSCOGGIN RIVER IN MAINE (MAY)

" *** much damage was caused by this flood $* * *$ at Brunswick, where there was a rise of 28 feet in the stage of the Androscoggin River" (Grover, 1937, p. 445).

SACO RIVER IN MAINE (MAY)

"This flood was called the greatest in thirty years." Many bridges and mills destroyed (Grover, 1937, p. 447).

"In 1691, Capt. George Turfey, built the Lower Mill so-called. This was repaired and kept running until 1814, when it was carried away in the great freshet" (Ridlon, 1894, p. 197).

For relative flood stages at West Buxton, Maine, refer to page 77.

\section{8}

MERRIMACK RIVER IN NEW HAMPSHIRE (SPRING)

"In the spring of 1818 occurred one of the most remarkable freshets recorded in the history of the Merrimack towns. The river was raised 21 feet above common high water mark" (Webster, 1913, p. 391).

CONTOOCOOK RIVER AT HENNIKER, N.H. (SPRING)

"A bridge repaired in 1811 was swept away by a freshet in the spring of 1818" (Cogswell, 1880, p. 82).

CHARLES RIVER IN MASSACHUSETTS (DATE UNKNOWN)

"*** the north end of the bridge at Watertown being swept away in that year" (Nelson, 1879, p. 128).

QUINEBAUG RIVER IN CONNECTICUT (DATE UNKNOWN)

"A Pomfret Woolen Manufacturing Company was incorporated in 1817, and erected buildings on the Mashamoquet, but it suffered severely from the great flood the following year" (Bayles, 1889 , p. 527).

SOUTH BRANCB ASHUELOT RIVER AT MARLBORO, N.H. (MARCH)

"March 1 and 2, 1818, remarkable rainy days that caused a great freshet" (Bemis, 1881). 
CONNECTICUT RIVER AT NORTH WALPOLE, N.H. (MAY)

"During Monday night, May 4, 1818, the water in the Connecticut river rose to a pitch which was said at that time 'not to have been exceeded within the memory of the oldest person in this vicinity'****.

"6* * * The water at this time was probably higher than in 1797, but the added protection of the guard gate saved a much greater misfortune.

"During the height of the flood, the water in the channel of the river was so high immediately under the toll bridge that it dashed in large quantities over the railing of the bridge, and at this point it was said to have been about sixty feet above the low water mark * * *" (Hayes, 1907, p. 393).

1820

SANDY RIVER AT FARMINGTON FALLS, MAINE (OCTOBER.10)

"A portion of the second bridge at the falls village was carried away by the freshet in $1814^{*} * *$ in the great freshet of October 16,1820 it was completely swept away" (Butler, 1885, p. 85).

For relative flood stages, refer to page 75 .

ANDROSCOGGIN RIVER IN MAINE (OCTOBER)

"On October 16 and 17 heavy rains produced a freshet, *** much damage was caused to the lower dam and to the highway bridge at Brunswick" (Grover, 1937, p. 445).

baco RIVER AT CONWAY N.H. (OCTOBER)

"From diary kept by Lt. James Walker, an early inhabitant of Fryeburg, we make some abstracts related to freshets on the Saco ***. About the middle of October, 1820, he writes of the greatest freshet 'I have known since I lived in Fryeburg' " (Ridlon 1894, p. 155).

MERRTMACK RIVER AT CONCORD, N.H. (OCTOBER 29)

From Mr. Benjamin Kimball's diary: "The highest freshet for 36 years" (Boutin, 1856, p. 771).

1823

PAWTUXE'T RIVER IN RHODE ISLAND (MARCH 5)

"A 24-hour rain on deep snow caused a disastrous freshet in Rhode Island and Connecticut * * *. At Pawtuxet, the river [rose] *** as high as the bridge ***"' (Perley, 1891, p. 229-231).

YANTIC AND SHETUCKET RIVERS IN CONNECTICUT (MARCH 6)

" * * * a freshet which carried away six bridges *** mills ***. The Methodist Chapel which stood on the bridge floated off ***" (Norwich Bulletin, Feb. 14, 1886).

BAKER AND PEMTGE WASSET RIVERS IN NEW HAMPSHIRE (FEBRUARY 12)

"*** a flood, the most appalling and tremendous ever known in this part of the country" (Musgrove, 1904, p. 473). 
CONTOOCOOK RIVER IN NEW HAMPSHIRE (FEBRUARY 16)

"Four bridges on the Contoocook River in New Hampshire were taken out in a flood on Feb. 16, 1824" (Musgrove, 1904, p. 105).

"A bridge at Penacook on the Contoocook River went out in the flood of 1824" (Brown, 1902, p. 15).

MERRIMACK RIVER NEAR CONCORD N.H. (FEBRUARY 12)

Mr. Benjamin Kimball's diary states: "East Concord bridge was carried off on the fifth day of April, 1819, again on the 12th of February, 1824" (Walker, 1896, p. 14).

PISCATAQUOG RIVER IN NEW HAMPSHIRE (FEBRUARY)

A diary of Stephen Collins reports: "February 12.-The greatest freshet ever known in this quarter. It took off many bridges and injured many mills" (Hadley, 1922, p. 218).

OTTAQUECHEE RIVER AT NORTH HARTLAND, VT. (FEBRUARY)

"Unusually high water in the Quechee carrying off bridges and mill-dams. Not as bad here as elsewhere along the Connecticut Valley" (from a notebook of newspaper clippings in the Woodstock, Vt. library).

1826

"Rain fell in torrents on March 24 causing a freshet that had been unparalleled in New England for more than thirty-five years. It extended not only through the northern New England states but into Canada and New York" (Perley, 1891, p. 232-235).

KENNEBEC RIVER BELOW AUGUSTA, MAINE (MARCH 26)

For relative flood stages at Hallowell, Maine, refer to page 76; for comparative flood information, see page 24.

Pemigewasset river at PLyModth, N.H. (March 24)

"Mr. Samuel Currier, born in $1790 * * *$ drilled a hole in the rock ledge on the right bank of the Pemigewasset River and placed in it a $1 \times 14$-inch iron bolt to mark the peak stage. This bolt is still in place about 1.7 miles downstream from the Geological Survey river measurement station at Plymouth, and has been found to have an altitude of $\mathbf{4 7 7 . 9 0}$ feet above mean sea level" (Grover, 1937, p. 449).

MERRIMACK RIVER IN NEW HAMPSHIRE (MARCH)

"This year was remarkable for its two freshets and drought. On the 24th of March, rain fell in torrents and raised the water in rivers to an unusual height. The rivers were at that time locked in ice two feet thich, when this was broken up the highest water since the freshet of 1785, was the result" (Musgrove, 1904, p. 474).

MERRIMACK RIVER AT AMOSKEAG DAM NEAR MANCHESTER, N.H. (MARCH 24)

"A spring freshet *** transferred the river into a swollen torrent ***" (Browne, 1915, p. 174). 
SAXTONS AND WILLIAMS RIVERS IN VERMONT (MARCH 25)

"A freshet, disastrous along the courses of the Saxtons and Williams Rivers and their tributaries ***" (Hayes, 1907, p. 396 ).

"On Saxtons River we learn that seven bridges have been swept away *** one paper mill, one grist-mill, and one dye house" (Bellows Falls Intelligencer, Apr. 3, 1826).

SACO RIVER AT FRYEBURG, MAINE (AUGUST)

"Torrential rains in the White Mountain area caused the Saco River at Conway, N.H., to rise 24 feet in 7 hours by exact measurement $* * *$. The reference mark of the flood of 1826 on a brass tablet placed in 1926 on a six-foot elm at Fryeburg, Maine, indicates a stage of the Saco River at Fryeburg 9.6 feet higher in August 1826 than that of March 1936. No records were found of an unusual flood in the lower reaches of the Saco River in 1826" (Grover, 1937, p. 447).

PEMIGEWASSET RIVER AT BRISTOL, N.H. (AUGUST)

"The Pemigewasset rose to a great height. Immense damage was done ***" (Musgrove, 1904, p. 474).

CONTOOCOOK RIVER IN NEW HAMPSHIRE (AUGUST 28)

"The flood of August, 1826, was one of the five highest freshets on the Contoocook River" (Lord, 1890, p. 282).

BLACK WATER RIVER NEAR WEBSTER, N.H. (AUGUST)

For comparative flood information, see oral communication by Mr. E. C. Gerrish, page 78.

MERRIMACK RIVER AT CONCORD, N.H. (A UGUST 30)

"*** the river rose 20 feet above low water mark ***" (Walker, 1896, p. 61).

SOUTH BRANCH ASHUELOT RIVER NEAR MARLBORO, N.H. (AUGUST 28)

"A great freshet * * *" (Bemis, 1881).

ANDROSCOGGIN RIVER IN MAINE (SEPTEMBER)

“*** heavy rains caused a freshet which swept away many bridges mostly in the upper reaches" (Grover, 1937, p. 445).

RIVERS IN MAINE (APRIL)

1827

"On April 24, 1827, a severe gale and heavy rains occurred in Maine and New Hampshire. ***The bridge at Kennebunk on the Kennebunk River was severely damaged, and two small bridges below it were carried away. On the Saco River the water was above the first story windows on the island above Spring's Bridge. At Biddeford a bridge was carried away. The Presumpscot river was also greatly flooded, and mills and bridges on it were destroyed. $* * *$ 
"On the Androscoggin river a great amount of property was destroyed * * *” (Perley, 1891, p. 247-248).

BANDY RIVER IN MAINE (APRIL)

"A bridge at the Falls Village was carried away by a freshet in April 1827" (Butler, 1885, p. 85, 314).

SACO RIVER IN NEW HAMPSHIRE AND MAINE (APRI)

Lt. James Walker, an early inhabitant of Fryeburg, wrote in his diary on April 4, 1827 that 5 inches of rain had fallen and two bridges had been carried away on the Saco River near Conway, N.H. (Ridlon, 1894, p. 155).

On the Saco River at Cornish, Maine, on May 1827, Saco lost one bridge, Buxton one bridge, Carr Mills one bridge plus several mills (office files of the U.S. Geological Survey in August, Maine).

\section{8}

QUinebaUg RIVER IN MassachusetTs (MaRCH)

"In the spring freshet of 1828 the big dam at the Globe gave way carrying destruction in the path of the flood" (Quinebaug Historical Society leaflets, v. 1, No. 1, p. 35).

AMMONOOSUC RIVER AT Bath, N.H. (AUGUST)

"** * a tremendous shower which carried off part of the mills at Bath ***" (Bess, 1883, p. 39).

MASCOMA RIVER NEAR LEBANON, N.H. (AUGUST OR SEPTEMBER)

"The records of 1828 indicate that sometime in August or early in September there was a great freshet, doing much damage * * *" (Downs, 1908, p. 248).

SLEEPERS RIVER NEAR ST. JOHNSBURY, VT. (SEPTEMBER 5)

“* * * heavy rains swelled the west branch of Sleepers River and washed away five bridges and several mills on the streams, including the works of the Fairbanks Brothers, the violence of the waters was so great at this time that a clothier's screwpress weighing 400 pounds, was swept down the stream and lodged on the meadow nearby half a mile below" (Fairbanks, 1912, p. 518).

WELLS RIVER AT WELLS RIVHR, VT. (SEPTEMBER)

“* * * a great flood, and the village of Wells River, was inundated and flooded. *** At this time the saw mill at the north end of the dam, before spoken of, was torn down sufficiently to relieve the great body of water that came down Wells River, from further flooding the village, the water being 4 to 6 feet deep in the upper end of Main street" (Wells, 1902, p. 169).

OTTAUQUECHEE RIVER IN VERMONT (SEPTEMBER)

"*** the great flood on the Quechee River and the brooks along the valley hereabout which occurred September 4, 1828" (Dana, 1889, p. 186). 
"September 4, 1828.-Similar to 1824 freshet; damage more extensive on Quechee River than in 1824 however" (from a notebook of newspaper clippings in the Woodstock library).

CONNECTICUT RIVERS AT BELLOWS FALLS, VT. (DATE UNKNOWN)

"Referring to the high water (of 1895) Mr. Moses Miller remembers nearly every flood from the time of Noah to the present day. He was about seven years old at the time of the flood of 1828 when the water was about the same height as during the past week but did not run through the tunnel because there was no tunnel there at that time" (Bellows Falls Times, April 18, 1895).

For comparative flood information, see statement referring to flood of 1828 on pages 23 and 34 .

SALMON BROOK NEAR GRANBY, CONN. (SEPTEMBER 4)

"On September 4, 1828 there was a freshet which did much damage all along the line, particularly at Granby, where for a second time the great Salmon Brook arch bridge was carried away" (Harte, 1938, p. 20).

1830

PEMIGEWASSET RIVER IN NEW haMPSHIRE (JULY)

"There was a great freshet in the Pemigewasset Valley. At the Moore house, just above the Pemigewasset bridge the water was two feet deep on the floor" (Musgrove, 1904, p. 474).

WHITE RIVER NEAR BETHEL, VT. (JULY)

"Probably the most terrible calamity to the town was the freshet in July, 1830. The flood took bridges, crops, mills and all in its way. *** In the narrowest parts of the valley of the branch, the water was 20 feet deep" (Bess, 1883, p. 39).

OTTAUQUECHEE RIVER IN VERMONT (JULY 27)

"A great freshet due entirely to rainfall. Damage along Ottauquechee limited" (from a notebook of newspaper clippings in the Woodstock library).

piscataquog RIVER at Goftstown, N.H. (AUGUST 6)

"A great freshet is mentioned in a list of notable events" (Hadley, 1922, p. 554).

SOUHEGAN RIVER AT MILFORD, N.H. (AUGUST 6)

"The water of the Souhegan *** reached the cellars of the Moore house, still standing, and then just completed.

"It was claimed by some who saw both the 1830 and that of '69 that in 1830, the water would have come close to the top of the railings of the stone bridge (not built until 1846 or 7 ) and have run over the wooden railway trestle built just above the county bridge in Pine Valley in the 1850's. The dam having been built in 1846 indicates relatively greater rise in 1830" (oral communi- 
cation by Mr. Andrew E. Rothovius, U.S. Weather Bureau cooperative observer at Milford, N.H., 1957).

1832

PISCATAqUIS RIVER IN MAINE (DATE UNKNOWN)

"The low bridge [in Gilford] was hardly completed before a very high freshet in 1832 swept it away" (Loring, 1880, p. 104).

SANDY RIVER IN FARMiNGTON FALLS, MAiNE (MAY)

For relative flood stages, refer to page 75 .

KENNEBEC River in MAiNe (MAY 22)

For relative flood stages at Winslow, Maine, refer to page 76.

"On the Kennebec River in Maine a Mr. Paine, employed in 1890 to make a report on old floods 'was sure the flood of 1832 was the worst experienced between 1761 and 1890" (Marriner, 1954 , p. 150,151$)$.

\section{7}

QUINEBAUG RIVER IN MASSACHUSETTS AND CONNECTICDT (DATE UNKNOWN)

The Southbridge Journal, Feb. 5, 1867, referred to the flood of 1837 in an account of the flood of 1867 , which was said to be the largest freshet in the mill stream since 1837.

HOUSATONIC RIVER AT CORNWALL, CONN. (DATE UNKNOWN)

Hart's Bridge was carried off in 1837 by a flood (Starr, 1936).

POQUONOCK RIVER IN CONNECTICUT (MARCH 23)

"Great flood. Poquonock River burst its dams one after another. *** Great damage in various parts" (from the journal of William Wheeler in Lathrop, 1930).

1839

SANDY RIVER NEAR FARMINGTON, MAINE (JANUARY 26)

"*** a great freshet damaging bridges up and down the river" (Butler, 1885, p. 86).

KENNEBEC RIVER IN MAINE (JANUARY)

"Very high water occurred and some of the streets in Hallowell and Gardiner were flooded"'(Grover, 1937, p. 443).

ANDROSCOGGIN RIVER AT NORTH TURNER, MAINE (JANUARY 27)

The bridge at North Turner was carried away "by the greatest freshet" (French, 1887, p. 97).

UITTLE ANDROSCOGGIN RIVER IN MAINE (JANDARY 26)

"A severe freshet. The saw-mill owned by Simeon Cummings was carried away by the ice" (Lapham and Maxim, 1884, p. 168).

PEMIGEWASSET RIVER NEAR BRISTOL, N.H. (JANUARY)

"There was a very heavy rain and an ice freshet was the result." (Musgrove, 1904, p. 474).

MERRIMACK RIVER NEAR SANBORNTON, N. H. (JANUARY 27)

"Another ice freshet similar to that of 1824" (Runnels, 1882). 
MERRIMACK RIVER NEAR CONCORD, N.H. (DATE UNKNOWN)

"It [a bridge at the junction of the Contoocook and Merrimack Rivers] was swept away by the great ice freshet which destroyed many bridges on the Merrimack" (Concord Monitor, March 2, 1896).

MERRIMACK RIVER AT AMOSKEAG FALLS NEAR MANCHESTER, N.H. (SPRING)

"The spring of 1839 witnessed the most disastrous freshet that had been known at Amoskeag to this date. This river rose so high that the water flowed over the island, and people living there had to take refuge in the upper story of the boarding house which stood on the highest point of land" (Browne, 1915, p. 174, 180).

WESTFIELD RIVER AT WESTFIELD, MASS. (JANUARY 26)

" 'Such a flood I never saw *** four feet above high water mark *** the high banks are all overflowed *** about 10 o'clock my cellar filled.' That comment was made by Miss Aurelia Taylor who built the house at 131 Main Street where Mr. Gagne lives now [1957]"' (Maschin, 1955).

For comparative flood heights, see page 94 .

FARMINGTON RIVER IN CONNECTICUT (JANUARY 26)

" *** there came a flood in the river when the ice in the river was two feet thick, and then the water rose $14 \frac{1}{2}$ inches higher than now" (Hartford Courant, Jan. 10, 1874).

1841

MERRIMACK RIVER AT CONCORD, N.H. (JANUARY 8)

Benjamin Kimball recorded in his diary for Januray 8, 1841, "A great freshet $* * *$ the water in the river rose 15 feet above the ice, and carried off Federal bridge and Free bridge ***" (Boutin, 1856, p. 771).

CONNECTICUT RIVER NEAR NORTH WALPOLE, N.H. (JANUARY 8)

"A sudden thaw and rain in the Connecticut valley in the winter of 1841 , caused a freshet $* * *$.

“*** At its highest point, the water at this time was one foot above the point reached in the great freshet of September, 1828 , the mark of which was still discernible, made with red paint, on the stone work of the abutment of the old bridge on Bridge Street. The rise of water in the eddy below the falls is recorded as being twenty-two and one-half feet $* * * "$ (Hayes, 1907 , p. 393).

CONNECTICUT RIVER AT HARTFORD, CONN. (JANUARY 9)

For relative flood stages, refer to page 85 .

NAUGATUCK RIVER IN CONNECTICUT (DATE UNKNOWN)

For comparative flood information, see page 29. 
1843

CONNACTICUT RIVER AT HARTFORD, CONN. (MARCH 29)

For relative flood stages, refer to page 85 .

RIVERS IN MAINE (APRIL)

On the Kennebec River very high water occurred in April, and some of the streets in Hallowell and Gardiner were flooded. The storm on the Androscoggin River was similar (Grover, 1937, p. 443).

baCO RIVER IN MAINE (MAX)

For relative flood stages at West Buxton, refer to page 77 and for comparative flood information at Saco, Maine, see page 45.

NEWFOUND LAKE IN NEW HAMPSHIRE (JUNE 17)

"There were very heavy rains this season, and the lake rose to a great height. The water covered the road just north of the bridge over the river at the outlet of the lake, and a flat stone was set in the ground to mark the high water point" (Musgrove, 1904, p. 474).

1846

MACHAS RIVER IN MAINE (DATE UNKOWN)

"The Machias flow was the greatest since 1779" (office files of Geological Survey, Augusta, Maine).

KENDUSKEAG RIVER IN MAINE (DATE UNKNOWN)

" *** The water was several feet deep in front of the old Hatch tavern and nearly up to the windows in the Exchange* * * "(Perley, 1891, p. 292-294).

PENOBSCOT RIVER IN MAINE (MARCH 29)

"The flood resulting from the storm of March 25-28 was very destructive on the Penobscot River, owing to the breaking up of ice of great thickness and to the formation of ice jams. The ice jam at Bangor was called the greatest in 100 years" (Grover, 1937, p. 440).

ANDROSCOGGIN RIVER IN MAINE (MARCH)

"During this flood much damage was caused by an ice jam on the Androscoggin River below Livermore Falls, Maine, which raised the water 24 feet in about 24 minutes ***. The greatest damage occurred at Livermore Falls" (Grover, 1937, p. 445).

KENNEBEC RIVER IN MAINE (APRIL)

"At Gardiner the river reached a height about 2 feet above that of 1826" (Grover, 1937, p. 443).

NEZINSCOT RIVER AT TURNER CENTER, MAINE (DATE UNKNOWN)

"All these mills [built from 1795 on] were in operation until carried away by the great freshet about 1845 [possibly 1846]" (French, 1887, p. 85). 
SALMON FALLS RIVER NEAR SOMERSWORTH, N.H. (DATE UNKNOWN)

"The dam on the Salmon Falls River * * * was washed away" (Perley, 1891, p. 292-294).

NAUGATUCK RIVER AT WATERBURY, CONN. (BPRING)

"Mr. Richerson claims to be the first man who ever rode in a row boat in Bank Street. I [Wm. W. Webster, Sr.] am an old resident of Waterbury and I think Mr. Richerson must be mistaken, for in the spring of the year 1846 I saw 4 or 5 row boats on Bank Street. At the same time the water came up to the Earl house basement" (Waterbury American, Feb. 7, 1896).

1850

NAUGATUCK RIVER IN CONNECTICUT (FEBRUARY 10)

"The rise in the Naugatuck at this point was within a few inches of the 1840 mark ***") Waterbury American, Feb. 15, 1850).

HOUSATONIC RIVER NEAR DERBY, CONN. (FEBRUARY)

"A result of the storm yesterday has been the breaking up of the ice in the river, and considerable of a freshet * * *" (Derby Journal, Feb. 9, 1850).

MERRIMACK RIVER NEAR CONCORD, N.H. (APRIL)

"The April freshet of 1850 submerged the whole intervale."

"May 1 and 6, Federal bridge injured and embankments of

B. C. \& M. Railroad washed away" (Lyford, 1896, p. 14, 16).

CONNECTICUT RIVER NEAR WELLS RIVER, VT, (APRIL)

"On the 28th of April, 1850, a rain set in, and the river rose higher than before since 1807" (Wells, 1902, p. 169).

NASHUA RIVER IN MASSACHUSETTS (MAY )

"The flood of May 6, 1850 took out twelve bridges *** and was caused, in part at least, by the breaking of the dam of Ashburnham Reservoir" (Fitchburg Sentinel, April 17, 1853).

NAUGATUCK RIVER IN CONNECTTCUT (SEPTEMBER)

“**** torrents of rain Monday night and Tuesday morning elevating the streams to an unusual height ***" (Waterbury American, Sept. 6, 1850).

RIVERS IN MAINE (APRIL)

1852

"April 18 to 20, a heavy rain fell on snow creating a severe freshet. *** The Kennebec river was extremely high, the water being eight feet deep on the wharves at Hallowell * * *. The Saco river also overflowed its banks at its mouth" (Perley, 1891 , p. $317-320$.

PEMIGEWASSET RIVER IN NEW HAMPSHIRE (APRIL)

"The Pemigewasset rose to a great height and nearly all the mills on the stream were compelled to suspend work on account of high water" (Musgrove, 1904, p. 474). 
WINNIPESAUKEE RIVER IN NEW HAMPSHIRE (APRIL)

"As it was the Winnipesaukee branch of the Merrimack rose suddenly to a great height ***" (Browne, 1915, p. 177-178). CONTOOCOOK RIVER IN NEW HAMPSHIRE (APRIL)

"A memorable freshet one of the five highest freshets on the Contoocook River" (Lord, 1890, p. 282).

"The stone bridge at Henniker was built about 1835 and was not damaged until the severe freshet in the early spring of 1852 , when the water forced its way around the north end of it, doing some damage" (Cosgwell, 1880, p. 252).

MERRIMACK RIVER AT PENACOOK, N.H. (APRIL 21-23)

"The freshet was the most destructive to property in the village, of any that had ever occurred" (Brown, D. A., 1902, p. 275).

MERRIMACK RIVER ABOVE CONCORD, N.H. (APRIL 23)

"Mr. Samuel B. Kidder, who was gate-keeper at the time, says, 'April 23, 1852, at four a.m. the river was the highest I've ever known it. The middle lock at the foundry completely covered by water. The balance levers only in sight. The water on the top of the gage 21 inches. This is the highest. freshet we have had on the Merrimack for some 70 years'" Browne, 1915, p. 177-178).

MERRIMACK RIVER AT NASHOA, N.H. (APRIL 23)

"At Nashua the flood of 1785 was about two feet higher than that of 1852" (Francis, 1885).

MERRIMACK RIVER AT LOWELL, MASS. (APRIL 23)

For relative flood discharges, refer to page 13, and for relative flood heights over Pawtucket Dam to page 80.

MerRimack river at LaWRench, Mass. (APRIL 23)

For relative flood stages, refer to page 81 .

The flood of 1852 on the Merrimack at Lawrence, Mass., was said to be the greatest flood in the lower valley of the Merrimack since 1785, in a report by the Corps of Engineers. (House Document 649, 71st Congress, 3rd Session, p. 20).

CONNECTICUT RIVER AT WHLLS RIVER, VT. (APRIL 24)

"The flood of April 24, 1852 was the greatest flood ever known there. The oldest inhabitant remembers floods in 1828, 1821 and even 1806 but he remembers nothing approximating so nearly to. the great deluge as we now witness. Caused by heavy rains and sudden melting of snow" (from files of Geological Survey, Hartford, Conn.).

MTLLERS RIVER IN MASSACHUSETTS (APRIL 22)

"A great flood in Millers River. *** This was the greatest and most destructive flood within the memory of the most aged. inhabitants" (Marvin, 1868, p. 396). 
1853

PENOBSCOT RIVER NEAR WEST ENFIELD, MAINE (NOVEMBER 13)

"The Penobscot River was the highest for 20 years. Kenduskeag Village Dam carried away with one life lost" (Grover, 1937, p. 440).

FARMINGTON AND STILL RIVERS IN CONNECTICUT (NOVEMBER)

"Winsted. The destruction [by the Still River] of property in our town has been very slight beyond that to roads and bridges" (Mountain County Herald, Nov. 19, 1853).

"The late storm has been productive of considerable damage in Farmington occasioned by the sudden rise of the Farmington River, causing a greater freshet than we have known for many years" (Hartford Courant, Nov. 17, 1853).

"Hitchcockville. The water commenced rising in this place, both in the Farmington and Still Rivers, $* * *$ and continued to rise very rapidly until the Farmington overflowed its bands $* * *$. Still River had become swollen to its utmost capacity. *** The north abutment of the dam, and its banks as well as that of the bridge were also swept away ***" (Mountain County Herald, Nov. 19, 1853).

BLACKBERRY RIVER IN CONNECTICUT (NOVEMBER)

"In Norfolk we learn that besides very great injuries done to the roads, the dam of the Welaka Company was considerable washed ***.

"At South Norfolk near the tannery of Mr. Roy's the river now occupies the place of a former road" (Mountain County Herald, Nov. 19, 1853).

hOUSATONIC RIVER AT GAYLORDSVILLE, CONN. (NOVEMBER)

"The water is said to be some 6 feet higher than at any point ever previously known by the oldest inhabitant" (Bridgeport Standard, May 1, 1854). Inasmuch as this statement must refer to the flood of Nov. 13,1853, the stage of the November flood on the present gage would have been about 20 feet. This stage corresponds to a discharge of approximately $60,000 \mathrm{cfs}$ or 60 cubic feet per second per square mile.

STILL RIVER (TRIBUTARY TO HOUSATONIC RIVER) IN CONNECTICUT (NOVEMBER)

"Tremendous Freshet! Great Loss of Property-The most destructive freshet ever experienced in this place ***. Generally the accumulation of water was so sudden as to baffle every attempt at rescue $* * *$. All the bridges on the Railroad but one, were swept off and tracks badly washed" (Danbury Times, Nov. 16, 1853).

SHEPAUG RIVER IN CONNECTICOT (NOVEMBER)

"One hundred and two years ago Albert L. Hodge of Roxbury wrote in his diary the following entries: 'November 13, 1853- 
Greatest flood ever known. $* * *$ Oldest inhabitant never saw the like. Done much damage" " (New Milford Times, Sept. 1, 1955).

A freshet on November 13, 1853 destroyed roads and bridges. It was said that a torrent of water fell for several hours raising the rivers and brooks to a point 3 feet higher than had ever been known (from files of the Geological Survey, Hartford, Conn.).

POMPERAUG RIVER AT SOUTHBURY, CONN. (NOVEMBER)

On October 2, 1957, Mr. M. P. Thomas of the Geological Survey learned from Mr. Clarence Stiles of Southbury, Conn., of the existence of a marked stone representing the height of the flood of November 1853 or April 1854. Thomas stated: "This stone was marked by $\mathrm{Mr}$. Jonathan Stiles, a great-uncle of $\mathrm{Mr}$. Clarence Stiles, but several years later, the date of 1850 was cut into the rock by $\mathrm{Mr}$. Clarence Stiles. It seems probable that the date is in error for there is no indication of any major flood in 1850. The stone is located on the south side of Poverty Road about 2 feet from the wheel track and 554 feet from the face of the east abutment of the White Oak Flood Bridge. Levels today to satisfactory floodmarks for the August 1955 flood indicate that the August 1955 flood was 4 feet higher than the flood of 1853 or '54 at this point."

NONEWAUG RIVER IN CONNECTICUT (NOVEMBER)

"Immense damage was done to the mills, factories, dams and bridges on the Nonewaug River and farmers on the flats lost great quantities of hay in the stack, fences, and etc." (Bridgeport Standard, Nov. 16, 1853).

HOUSATONIC RIVER IN CONNECTICUT (NOVEMBER)

Also in the Bridgeport Standard for Friday, January 9, 1874, the statement was made that the flood of 1874 was the highest in Derby for 20 years and comparative stages were indicated for a number of floods between 1853 and 1874 . The stage for 1853 is given as 17 feet and 7 inches, which was exceeded in 1857 and 1874. For comparative flood heights, see page 31 .

NAUGATUCK RIVER IN CONNECTICUT (NOVEMBER)

"South Norfolk, November 14-We have just been visited with one of the most destructive freshets ever known in this vicinity. $* * *$ A greater loss was never sustained by flood in the State" (Waterbury American, Nov. 25, 1853).

"Several of our oldest citizens $* * *$ agree that it exceeded the flood of 1801, the greatest on record, from a foot and a half to two feet $* * *$ the flood of 1841 stood out next as a prominent point of reference and was nearly equal to its predecessor of 1801" (Waterbury American, Nov. 25, 1853). 
Thomaston: "An old gentleman of Plymouth, informs us that his father and himself have marked on a rock on the bank of the Naugatuck, the height of each freshet for a hundred years past, and that the Indians did the same before them. He finds the present to be 4 feet higher than it was ever known before" (Danbury Times, Nov. 23, 1853).

Naugatuck: "Great damage. Water was 25 inches over the floor of the Manufacturers Bank" (Bridgeport Standard, Nov. $16,1853)$.

"A terrific flood raised the water at Seymour to 18 feet 11 inches and swept away bridges ***" (Ansonia Sentinel, Sept. $8,1955)$.

"November 13, 1853, the water rose in the Naugatuck 17 feet 7 inches $* * *$ and was one foot higher than in the great freshet of 1841" (Grover, 1937, p. 460).

1854

SHETUCKET RIVER NEAR NORWICH, CONN. (FEBRUART)

"At 3 o'clock this morning the water was higher in the Shetucket than it has been at any time before within the last 15 years-so we are told. It rose to the height of eighteen inches to two feet above the lower track of the Norwich and Worcester Railroad, at the Freight depot" (Hartford Courant, Feb. 13, 1854).

HOUSATONIC RIVER IN CONNECTICUT (FEBRUARY)

"Gaylord's Bridge was carried away about 5 o'clock Sunday evening." Many other bridges also destroyed. "Had it not been for the ice little damage would have been done" (Mountain County Herald, Feb. 13, 1854).

NAUGATUCK RIVER IN CONNECTICUT (FEBRUARY)

"Wednesday was marked in this locality with the third disastrous flood that has occurred in the Naugatuck Valley this season *** and in which the Railroad, more particularly, has suffered interruption and damage to an extent hitherto unprecedented * * *” (Waterbury American, Feb. 10, 1854).

HOUSATONIC RIVER IN CONNECTICUT (MARCH)

"The Housatonic as far up as New Milford is said to be three feet higher than has been known for many years. The water at that point was up over the railroad bridge, a circumstance that has never before occurred" (Litchfield Enquirer, Mar. 4, 1854).

NAUGATUCK RIVER IN CONNECTICUT (MARCH)

"For the fourth time this winter, the Naugatuck Valley has been visited with a sudden and destructive flood" (Mountain County Herald, Mar. 4, 1854).

710-949-64-3 
FISH RIVER NEAR FORT KENT, MAINE (SPRING)

"The river cut around the east end of the mill and washed out three acres of land" (Wiggin, 1922, p. 172).

PISCATAQUIS RIVER AT FOXCROFT, MAINE (APRIL)

"A high spring freshet in April 1854 swept the Scot Mill in Foxcroft away taking the Foxcroft Bridge with it. The mill had been built in 1834 or 1835 " (Lowell, 1935, p. 132).

ANDROSCOGGIN RIVER IN MAINE (MAY)

"Although" there was little damage, this was said to be the greatest freshet since $1814 * * *$ at Brunswick" (Grover, 1937, p. 445).

STILL RIVER IN WINSTED, CONN. (MAT)

"In this town the streams were not so high as in the freshet in November" (Mountain County Herald, May 6, 1854).

LITTLE RIVER AT HANOVER, CONN. (MAY)

"In Hanover, considerable damage done * * *" (Connecticut Whig, May 4, 1854).

FARMINGTON RIVER IN CONNECTICUT (MAY)

"Windsor Bridge, over Farmington River is gone:

*** At

Simsbury, the Farmington River rose very rapidly at its greatest height on Sunday evening was about one foot higher than in the flood of 1801" (Hartford Courant, May 2, 1854).

CONNECTICUT RIVER IN MASSACHUSETTS AND CONNECTICUT (MAY 1)

For relative flood stages, refer to page 85 .

QUINNIPIAC RIVER NEAR WALLINGFORD, CONN. (MAY)

"In the spring of 1854, a section of our dam was washed away carrying with it a large portion of our factory, machinery, tools and stock" (Atwater, p. 113).

EAST BRANCH hoUSATONIC RIVER AT COLTSVILLe, MASS. (MAY)

"At Van Deusenville, about sixty feet of the Housatonic Railroad was washed away" (Hartford Times, May 5, 1854).

hoUSATONIC RIVER AT PITTSFIELD, MASS. (MAY)

"Heavy Rains and Flood. *** the Housatonic River rose to a height as great as ever known before. At the cotton mills in this village the water was one inch higher than it has been since the erection of that establishment" (Pittsfield Sun, May 4, 1854).

housATONIC RIVER AT GREAT BaRRINGTON, MASS. (APRIL 39)

"In this village, the Housatonic River rose to a very great height, overflowing the basements of buildings situated on its banks" (Berkshire Courier, May 4, 1854).

HOUSATONIC RIVER AT GAYLORDSVILLE, CONN. (MAY 1)

"Gaylordsville, May 1, 1854. Highest water mark known. Height of water between piers 21 feet 3 inches. Got the measure 
Apr. 16, 1902" (G. H. Monroe, Geological Survey observer's notebook for 1901-02).

"Spring of $1854 * * *$. The record says that the water rose 23 feet above normal (Evans, June 1946).

On the basis of the above observation, a stage of 26 feet on the present gage is possible for the flood of May 1, 1854; this stage corresponds to a discharge of approximately $100,000 \mathrm{cfs}$ or 100 cubic feet per second per square mile.

STILL RIVER NEAR DANBURY, CONN. (MAT)

"The Great Flood. We hardly get our bridges on their feet, before they are 'off' again. The loss of property by the freshet of Saturday night and Sunday morning will probably exceed, in our own vicinity, that of the freshet of February [1854] and November [1853]. Many dams destroyed and all bridges but one. Streams swollen beyond all precedent" (Danbury Times, May 4, 1854).

hoUSATONIC RIVER AT STEVENSON, CONN. (APRIL 30)

The Birmingham River stage was 19 feet $8 \frac{1}{2}$ inches. (Grover, 1937 , p. 459). "The greatest freshet known $* * * 26$ " higher than in November last ***." (Derby Journal, May 4, 1954).

NAUGATUCK RIVER IN CONNECTICUT (APRIL 39)

"On the thirtieth of April 1854, there was another great flood, the water rising in Waterbury within eighteen inches as high as in the previous November. At Derby, owing to a greater freshet in the Housatonic, the water was highest in April" (Bronson, 1858, p. 111).

"Ansonia, Apr. 30, 1854. In height and volume and consequent destruction of property, the present freshet far exceeds that of any former period. Nothing but destruction meets the eye in every direction. At this place the water rose about 10 feet, a foot higher than ever known before" (Hartford Times, May 1, 1854).

1855

ABERJONA RIVER AT WINCHESTER, MASS. (FEBRUARY 16)

"Those who have known this place for fifty years, have never seen the water so high as on February 16, 1855. It may be proper to add that the causes of this unprecedented flood were heavy rains combined with melting snow and ice on the surface of Wedge Pond, producing an unusual overflow, together with obstructions of ice in the culverts under the railroad, which prevented the regular discharge of the water" (Youngman, 1855, p. 184).

SANDY RIVER AT FARMINGTON FALLS, MAINE (OCTOBER 13)

For relative flood stages, refer to page 75 . 
KENNEBEC RIVER AT NORRIDGEWOCK, MAINE (OCTOBER 14)

For relative flood stages, refer to page 75 .

LITTLE ANDROSCOGGLN RIVER IN MAINE (OCTOBER)

"The Androscoggin rose seven feet and all the low lands along its course were flooded. Considerable damage was done to roads and bridges" (Lapham and Maxim, 1884, p. 180).

1857

SHETUCKET RIVER NEAR NORWICH, CONN. (FEBRUARY)

"Old inhabitant called it the severest freshet for at least more than thirty years. (2" higher than 30 years ago)" (Evening Courier, Feb. 10, 1857).

"Altogether, it is the highest flood ever known in this city excepting always one which occurred near the beginning of the present century ***' (Evening Courier, Feb. 12, 1857).

For comparative heights, see p. 48.

FARMINGTON RIVER IN CONNECTICUT (FEBRUARY)

"Its course is still marked with speaking evidence of the February flood. There are stout trees barked and broken high in the air, banks caved in and new channels dug ***. At Pleasant Valley on the East side of the river it is scarcely possible to get about on account of the wilderness of ice thrown in upon the village" (Mountain County Herald, March 13, 1857).

NAUGATUCK RIVER IN CONNECTICUT (FEBRUARY)

"The Great Flood of 1857-The thaw and rainstorm which reached its ultimatum on Sunday night of the present week has probably exceeded in extent and magnitude any other event of that nature that has occurred for years.

"The causes which produced these destructive results was not that the waters in the rivers were higher than heretofore-that was not the case by a number of feet but is to be attributed to the unusual firmness and thickness of the ice on the Housatonic.

"On the east (Derby) side of the river-the floor of the Depot of the Naugatuck Railroad Co. was covered to a depth of four feet $* * *$ twenty three inches higher in the depot than it was ever known before" (Waterbury American, Feb. 13, 1857).

1859

MERRIMACK RIVER AT AMOSKEAG FALLS, MANChESTeR, N.H. (MARCH 18)

"The worst ice frèshet the oldest inhabitant could recall" (Browne, 1915, p. 178).

MERRIMACK RIVER NEAR CONCORD, N.H. (DATE UNKNOWN)

"A few miles upstream at Concord, the stage of the $1859 \mathrm{flood}$ was recorded at 17.98 feet on the Concord city datum" (Lyford, 1896 , p. 14). 
MERRIMACK RIVER AT LOWELL, MASS. (MARCH 20)

This flood was reported to have a head of 10 feet and 3 inches at Pawtucket Dam, the highest flood recorded since 1834 with with the single exception of the 1852 flood (Francis, 1885).

For relative flood discharges, refer to page 13.

CONNECTICUT RIVER IN MASSACHUSETTS AND CONNECTICUT (MARCH 20)

For relative flood stages, refer to page 85 .

OTTAUQUECHEE RIVER NEAR WOODSTOCK, VT. (JULY 25)

"Definitely one of the memorable floods for the Ottauquechee. Water probably higher than at any time since 1811" (from a notebook of newspaper clippings in the Woodstock, Vt., library).

1861

FARMINGTON RIVER NEAR RIVERTON, CONN. (NOVEMBER)

"Hartland-During the storm of last Saturday night six considerable bridges were carried off-four of them upon the Hollow stream the east Branch of the Farmington and one each in the east and west society. By the best data the East Branch has not been so high for a period of forty years (Winsted Herald, Nov. 8, 1861).

\section{2}

CONTOOCOOK RIVER IN NEW HAMPSHIRE (APRIL)

A freshet of April 1862 is listed as one of the five highest up to 1890 (Lord, 1890, p. 282).

MERRIMACK RIVER AT CONCORD, N.H. (APRIL)

The river was very high, but not as high by 2 or 3 feet as it was in April 1852 (Webster, 1913, p. 396).

The flood of April 22, 1862, at Concord was 19.4 feet above the city datum (Lyford, 1896, p. 14).

PISCATAQUOG RIVER IN NEW HAMPSHIRE (APRIL 20)

High water reported (Hadley, 1922, p. 554).

MERRIMACK RIVER NEAR MANCHESTER, N.H. (DATE UNKNOWN)

High water at Amoskeag Falls reported in the diary of $\mathrm{Mr}$. S. B. Kidder, the gate keeper (Browne, 1915, p. 180).

MERRIMACK RIVER AT LOWELL, MASS. (APRIL 20)

A stage of 10 feet 5 inches was recorded on April 20, 1862, on Pawtucket Dam (Francis, 1885).

CONNECTICUT RIVER NEAR NORTH WALPOLE, N.H. (APRIL 20)

"The highest water ever reached in the Connecticut at Bellows Falls was that of Saturday, April 19, 1862. It was said at the time that all the high water marks were submerged in the early part of Saturday and the river must have risen at least six feet higher than was ever known before. There was no ice in the river, it having gone out earlier, and there was no rain at this time. 
"Early in the day, Saturday, Superintendent Sloat saw the necessity, for the first time since the tunnel and railroad were constructed in 1850, of building a dam across the upper end of the tunnel $* * *$. At dark the water in the tunnel dam stood about two feet above the rails, and it continued to rise nearly all night. Old inhabitants estimate that at its highest point it stood six feet above the rails. [Add 18 inches to this to compare it with the 1927 and 1936 floods]. *** The water was two feet deep on Canal Street just above the bridge.

"At this time there was a high water mark on the abutments of the bridge across the canal on Bridge Street, made with red paint, in 1828 and at this time the water rose 5 $\frac{1}{2}$ feet higher than this mark" (Hayes, 1907, p. 393).

CONNECTICUT RIVER IN MASSACHUSETTS AND CONNECTICUT (APRIL)

For relative flood stages, refer to page 85 .

STILL RIVER AT BURRVILLE, CONN. (JUNE 7)

"At Burrville at 7 p.m., the reservoir of Capt. Milo Burr, a sheet of water covering some 75 to 100 acres, burst through its dam. $* * *$ All the bridges between Burrville and Winsted are swept away, both upon the railroad and highway" (Waterbury American, June 13, 1862).

\section{5}

CONTOOCOOK RIVER NEAR PENACOOK, N.H. (DATE UNKNOWN)

The bridge at Horse Mill, and that at Sewell's Falls were both swept away, or injured so seriously that they had to be replaced (Brown, D. A., 1902, p. 275).

MERRIMACK RIVER NEAR CONCORD N.H. (DATE UNKNOWN)

Damage was caused by a freshet at Sewell's Falls and at Free, Federal, and Concord bridges (Lyford, 1896, p. 16).

MERRIMACK RIVER AT LOWELL, MASS. (MARCH 19)

A stage of 10 feet and 6 inches was recorded at Pawtucket Dam (Francis, 1885).

1866

FRENCH RIVER AT WEBSTER, MASS. (FEBRUARY 17)

"The thaw and rise of the week past raised the streams in this vicinity above high-water mark" (Webster Times, Feb. 17, 1866).

MUDDY BROOK NEAR WOODSTOCK, CONN. (FEBRUARY)

"Serious Disaster in South Woodstock. The large reservoir at South Woodstock, Conn., for supplying water to some dozen mills in that place broke $* * *$ the large body of water and ice $* * *$ carrying away everything in its course $* * *$. We hear of no damage of consequence done at places below" (Webster Times, Feb. 17, 1866). 
HOUSATONIC RIVER AT BIRMINGHAM, CONN. (FEBRUARY 21)

A stage of 13 feet $1 \frac{1}{2}$ inches and possible ice effect was recorded (Grover, 1937, p. 459).

PENOBSCOT RIVER AT TREAT'S FALLS, MAINE (SPRING)

'During the 'heavy freshet' in the spring of this year Mr. Hiram F. Mills, a well-known hydraulic engineer, reported the flow * * * as 96,000 second-feet" (Grover, 1937, p. 440).

PASSUMPSIC RIVER AT PASSUMPSIC, VT. (APRIL 25)

"The high water of April 25, flooded the streets and swept off the lower bridge across the Passumpsic at Center Village, two Moose River bridges and one on Sleeper's River (west branch)" (Fairbanks, 1912, p. 518).

WAITS RIVER IN VERMONT (APRIL)

"In the latter part of the winter of 1866, occurred a remarkable freshet in Waits River, which tore up and swept away the thick ice in a frightful manner *** "(McKeen, 1875, p. 50).

1867

RIVERS IN RHODE ISLAND AND CONNECTICUT (FEBRUARY)

“* * * terrible and disastrous floods ***. The names of the rivers upon which the heaviest damage fell are the Woonasquatucket, Pawtuxet, Blackstone, Mornassuc, Ten Mile River and Yantic. The damage sustained in the Shetucket, Quinebaug and Yantic, which affect Eastern Connecticut, is estimated at $\$ 200,000$. So great and disastrous a flood has not occurred there for over thirty years" (Tolland County Journal, Feb. 21, 1867).

BLACKSTONE RIVER NEAR NORTHBRIDGE, MASS. (DATE UNKNOWN)

For relative flood stages, refer to page 81 .

FRENCH RIVER AT WEBSTER, MASS. (FEBRUARY)

"Many freshets were caused, which resulted in a great deal of damage to bridges, buildings, railroads, etc" (Webster Times, Feb. 16, 1867).

QUINEBAUG RIVER AT JEWETT CITY, CONN. (FEBRUARY)

"The dams at Danielson and Plainfield have gone by the board ***. The largest freshet *** since 1837" (Southbridge Journal, Feb. 15, 1867).

WHITE RIVER AT WEST HARTFORD, VT. (FEBRUARY 10)

"The greatest and most disastrous freshet ever known *** during which the village of West Hartford was inundated * * * the whole body of ice suddenly checked, thereby forming a dam which caused the water to set back to such an extent that in less than 20 minutes thereafter 16 houses in this village were submerged above the first floor ***. 
"On the 14th of Feb. and before any material efforts had been made to restore order, the water rose higher than ever before ***" (Tucker, 1889, p. 25).

HOUSATONIC RIVER AT BIRMINGHAM, CONN. (FEBRUARY 10)

A stage of 14 feet $\%$ inches was recorded (possibly affected by ice) (Grover, 1937, p. 459).

NAUGATUCK RIVER NEAR DERBY, CONN. (MARCH 15)

" *** rose rapidly until at the mouth of the river it was fourteen feet and five inches above low water mark" (Sharpe, 1879).

\section{8}

CONNECTICUT RIVER AT WINDSOR, VT. (FEBRUARY 25)

A stage of 30 feet, which was $2 \frac{1}{2}$ feet higher than ever known before, was reported (notes by Mr. W. W. Neifert concerning floods on the Connecticut River at Hartford, Conn.; in the U.S. Weather Bureau Office in Hartford, Conn.).

1869

STILL RIVER AT DANBURY, CONN. (FEBRUARY)

"About 7 o'clock last Sunday evening the upper Kohanza dam gave way, letting down the water with such force as to carry away the lower dam. The water of the two dams carried all before it" (Winsted Herald, Feb. 5, 1869).

MERRIMACK RIVER NEAR CONCORD, N.H. (APRIL 22)

"The river $* * *$ rose rapidly, the water $* * *$ in the engine room of the Concord Shops $* * *$ within two feet of high water mark in 1862, the highest point indicated by any fixed mark" (Concord Monitor, April 22).

A stage of 18.22 feet above the city's datum was recorded at Concord (Lyford, 1896, p. 14).

MERRIMACK RIVER NEAR MANCHESTER, N.H. (APRIL 23)

At Amoskeag Manufacturing Co., the river reached a stage of 79.375 feet (Browne, 1915, p. 181).

CONNECTICUT RIVER NEAR NORTH WALPOLE, N.H. (APRIL 2s)

"The second time in the experience of the Vermont Valley railroad when it became necessary to dam the upper end of the tunnel at Bellows Falls was Wednesday, April 23, 1869. The height of the water at the tunnel was greatest at 9 a.m., and was within eighteen inches of the record of 1862" (Hayes, p. 393).

CONNECTICUT RIVER IN MASSACHUSETTS AND CONNECTICUT (APRIL 22)

For relative flood stages, refer to page 85.

STILl AND MAD RIVERS NEAR WINSTED, CONN. (JUNE)

"The water in Mad river had risen about eight feet, carrying away [two dams]. Water to a depth of three feet ran through Main and Elm streets for some distance. Six feet of water was 
on the Clarke house floor and all the cellars in the vicinity were nearly full" (Waterbury American, July 1, 1869).

FARMINGTON RIVER IN CONNECTICUT (JUNE 28)

"Twenty-five bridges, great and small, were carried off" (Litchfield Enquirer, July 8, 1869).

BLACKBERRY RIVER NEAR NORFOLK, CONN. (JUNE 28)

"Shepard's dam was carried away and his tannery flooded to the depth of 3 feet ***" (Winsted Herald, July 9, 1869).

HODSATONIC RIVER AT GAYLORDSVILLE, CONN. (JUNE)

"Considerable damage to the Housatonic Railroad. *** West Cornwall is in ruins * * *" (Waterbury American, June 30, 1869).

"Terrific Storm and Freshet:- * * * The stream that empties into the Housatonic at West Cornwall $* * *$ At Cole's saw mill the water was 18 inches above the highest mark ever made on it ***" (Litchfield Enquirer, July 1, 1869).

NAUGATUCK RIVER IN CONNECTICUT (JUNE)

"Every bridge between Wolcottville and Winsted is carried away. The protection dam at Plymouth is also gone" (Waterbury American, June 30, 1869).

"At Litchfield Station the river rose fifteen feet, flooding the depot floor one foot deep ***" (Waterbury American, July 1, 1869).

"Much damage was done in Cotton Hollow, the bridge and several buildings were washed off. $* * *$ the rise in the water in the river was about fifteen feet" (Litchfield Enquirer, July 1, 1869).

"The water at Litchfield was. 14" higher than in the great freshet of Nov. 1853" (Waterbury American, July 2, 1869).

"Thomaston-On Monday evening [June 28] the water in the Naugatuck rose in one hour to 12 feet above low water mark * * *' (Litchfield Enquirer, July 8, 1869).

The flood of October $3-4,1869$ “*** Covered most of New England and extended as far south as Virginia. Lasted 36 hours and resulted in one of the greatest freshets that has ever occurred in New England. Rainfall 6 to 12 inches with a maximum recorded of 12.35 inches at Canton, Conn." (Kinnison, 1929, p. 84).

PENOBSCOT RIVER AT OLD TOWN, MAINE (OCTOBER)

“*** River rose 9 feet ***” (Grover, 1937, p. 440).

SANDY RIVER IN MAINE (OCTOBER)

"Much damage occurred along the Sandy River, and many bridges were lost"' (Grover, 1937, p. 441). 
KENNEBEC RIVER IN MAINE (OCTOBER)

For relative flood stages at Norridgewock, Maine, and at Winslow, Maine, refer to pages 75, 76.

ANDROSCOGGIN RIVER AT GORHAM, N.H. (OCTOBER)

"A freshet, the likes of which have not been known since 1826" (Concord Monitor, Oct. 8, 1869).

ANDROSCOGGIN RIVER IN MAJNE (OCTOBER)

"*** known as the pumpkin freshet, was called the worst since $1826 * * *$. At the Columbia Mill, in Lewiston, Maine, the stage of the river was 3 feet below that which occurred in 1896" (Grover, 1937, p. 445).

SWIFT FIVER NEAR ROXBURY, MAINE (OCTOBER)

The river rose 30 feet in 12 hours (Geological Survey district office files at Augusta, Maine).

LITTLE ANDROSCOGGIN RIVER IN MAINE (OCTOBER 3)

"A terrible freshet ***" (Lapham and Maxim, 1884, p. 192).

SACO RIVER IN MAINE (OCTOBER 3, 4)

"The rainfall ranged from 3 inches in the lower Saco River Basin to 6 inches and more in the upper portions of the basin. *** The dam recently constructed at Union Falls went out" (Grover, 1937, p. 448).

PEMIGEWASSET RIVER NeAR WOODSTOCK, N.H. (OCTOBER)

“*** a flood in the fall of 1869 was a major affair in Woodstock, it came up over the roadway at Woodstock between the bridge and the base of the hill near the railroad track ***" (D. B. Baston, written communication, 1957).

On the Pemigewasset River near Plymouth, N. H., a railroad spike in a butter-nut tree had an elevation at the highest stage of the 1869 flood of 480.3 feet. This height was exceeded in 1895, 1927, and 1936 (Grover, 1937, p. 449).

BAKER RIVER AT WENTWORTH, N.H. (OCTOBER)

"The flood of October was said to be the greatest freshet known to the last generation. As a result of four days and nights of heavy rain all streams reached probably the highest point ever recorded up to that time" (Plummer, 1930, p. 314).

PEMIGEWASSET RIVER AT BRISTOL, N.H. (OCTOBER 4)

"The most severe rainstorm and freshet since 1826" (Musgrove, 1904, p. 474).

CONTOOCOOK RIVER IN NEW HAMPSHIRE (OCTOBER)

This flood was reported as one of the five highest known (Lord 1890, p. 282). 
MERRIMACK RIVER NEAR CONCORD, N.H. (OCTOBER 5)

A stage of 20.18 feet on the city datum was reached. This was the highest stage recorded at that point since 1851, when records were first kept, but was exceeded after that date in 1895 and 1896 (Lyford, 1896, p. 14).

"The water reached a point seven inches higher than the highest water mark ever reached since the shops [Concord Shops] were built, and higher than any living person in this city remembers to have seen it" (Concord Monitor, October 6, 1869).

PISCATAQUOG RIVER NEAR GOFFSTOWN, N.H. (OCTOBER 3, 4)

"*** Most of the roads were so badly washed as to be impassable. Many of the bridges carried away including the one at the village" (Hadley, 1922, p. 280).

MERRIMACK RIVER NEAR MANCHESTER, N.H. (OCTOBER 4)

At Amoskeag Manufacturing Co., a stage of 80.9 feet was recorded (Browne, 1915, p. 181).

SOUHEGAN RIVER AT MILFORD, N.H. (OCTOBER)

"Mr. Emerson, born 1870, stated he was told that the water in 1869 reached practically to the rear of the present Methodist church, then the Baptist church, and swirled very close to the top of the knoll on which the postoffice now stands" (A. E. Rothovius, U.S. Weather Bureau cooperative observer, Milford, N.H. written communication, 1957).

For comparative flood heights pertaining to the flood of 1936, see page 80 .

MERRIMACK RIVER AT LOWELL, MASS. (OCTOBER 3, 4)

"The effect of this rain storm at Lowell was to raise the water in the Merrimack 10 feet above the Pawtucket Dam" (Francis, 1885).

For relative flood discharges, refer to page 13.

WILLIMANTIC RIVER IN CONNECTICUT (OCTOBER)

"The water at Willimantic and at other points was then far above the highest point it is known to have before attained during the memory of any persons now living there" (Providence Journal, Oct. 6, 1869).

HOP RIVER NEAR COLUMBIA, CONN. (OCTOBER 4)

"In the town of Union, the dam at Walker's mill was carried off. In North Coventry the Skunkamug *** was $* * *$ a wide and mighty torrent; as also was the gentle purring Ash Brook ***" (Cole, 1888, p. 83).

NATCHAUG RIVER AT WILlimantic, CONN. (OCTOBER 4)

At least 12 bridges in Union were swept away, as was the dam at Orvin Walker's sawmill (Southbridge Journal, Oct. 22, 1869). 
QUINEBAUG RIVER NEAR WESTVILLE, MASS. (OCTOBER 4)

"The oldest inhabitant of Southbridge had never seen anything like the extent of the flood of October 4" (Southbridge Journal, Oct. 8, 1869).

PASSUMPSIC RIVER IN VERMONT (OCTOBER)

"Passumpsic River at the Center Village was two and one-half feet higher than any former record; streets and houses were flooded ***" (Fairbanks, 1912, p. 518).

SLEEPERS RIVER NEAR ST. JOHNSBURY, VT. (OCTOBER)

"** * in the new brick engine house, the engine was submerged; east of this was the Scale Packing Shop, originally the grist mill built by Joseph Fairbanks in 1815, and the only survivor of early times; under the force of the flood it tottered and fell with a terrific crash and was carried off' (Fairbanks, 1912, p. 518).

AMMONOOSUC RIVER IN NEW HAMPSBIRE (OCTOBER)

"The waters of the Ammonoosuc River rose with great rapidity on Monday carrying with them every dam or bulkhead on its whole course.

"Lisbon in early times had many floods, year after year, and several times sweeping every bridge on the Ammonoosuc downstream, but the most disastrous flood Lisbon ever experienced was in 1869" (from a notebook of newspaper clippings in the Woodstock, Vt., library).

WELLS RIVER IN VERMONT (OCTOBER)

For comparative flood heights pertaining to the flood of 1927 , see page 70, oral communication by Mr. H. Brown of S. Ryegate, Vt., 1957.

OMPOMPANOOSUC RIVER AT UNION VILLAGE, VT. (OCTOBER)

Mr. R. B. Gould of Union Village, Vt., stated that some of the "old timers" in that vicinity had told him about a flood in the 1860's, which must have been the flood of October 1869, that was much higher than the 1927 flood. Mr. Gould remembers their telling how the water surrounded his house. This fact would indicate that the 1869 flood was about 2 feet higher than the 1927 flood. The 1869 flood destroyed the covered bridge in Union Village which, after being replaced, survived the 1927 flood. There is no evidence to indicate whether the bridge was replaced at the same elevation (oral communication, 1957).

WHITE RIVER IN VERMONT (OCTOBER)

"Since 1830 no similar event has occurred more notable, probably, than that of September, 1869, when highways and bridges sustained the most serious damage of anything in Braintree" (Bess, 1883, p. 39). 
For comparative flood heights pertaining to the flood of 1927 in South Royalton, Vt., see oral communication by Mr. G. Ainsworth, page 70 .

"The rise of water was entirely unprecedented in Sharom. It surrounded the dwelling of Mr. Joseah Walker, floating his ground floor to the depth of six inches $* * *$.

"White River at Royalton was higher than ever before known since the settlement of the country ***" (from a notebook of newspaper clippings in the Woodstock library).

MASCOMA RIVER AT WEST CANAAN, N.H. (OCTOBER)

"In the first Lebanon directory of 1882 the mention is made of the great flood of 1869 when the water stood 4.5 feet above the crest of the dams" (a statement by Mr. S. H. Stevens in a surveyor's fieldbook entitled "Highways, Number 15," in the town hall of Lebanon, N.H.).

For comparative flood information, see page 82 .

OTTAUQUECHEE RIVER AT NORTH HARTLAND, VT. (OCTÓber)

"How does this flood compare in height with other remarkable floods known to have occurred on the Quechee? It rose thirtyeight inches above the flood that took place in July, 1859, according to careful observations made in each instance. It was at least two feet higher than the great flood of September, 1828. This conclusion has been come to after fixing as carefully as possible the height of that flood from well ascertained facts. But in comparing the last with the two earlier floods it must be borne in mind that the bed of the river all along through this village is today fully three feet lower than it was twenty and forty years ago. The recent flood, therefore, was that much deeper at the same level than the former ones.

"Considerable effort has been made to ascertain the height of this flood in the Quechee. The most satisfactory testimony is that of Mr. George W. Samson, who reckons that the water rose as high in the river in front of his house during the freshet of last Monday as it did in 1811. But the channel of the river at that point is now broader and deeper than it was in 1811, and would require, therefore, a greater volume of water to fill it equally as high. Conclusions can be drawn accordingly" (from a notebook of newspaper clippings in the Woodstock, Vt., library).

BLACK RIVER IN VERMONT (OCTOBER)

"The great freshet, in the autumn of $1869 * * *$. Mr. Mike Tully's house [the first frame house built in the village in 1791] went off ***" (Hubbard and Dartt, 1895, p. 37, 135, 160). 
WILLIAMS RIVER IN VERMONT (OCTOBER 4)

"The little village of Bartonsville was entirely ruined during this freshet by the change in the course of the river whereby the two valuable paper mills, then being operated there, were left over a quarter of a mile from the new location of the river. $* * *$ Where the present bed of the river is, formerly stood four dwellings and the railroad depot" (Hayes, 1907, p. 405).

CONNECTICUT RIVER NEAR NORTH WALPOLE, N.H. (OCTOBER)

"The Connecticut rose rapidly, but its tributary streams easily rose beyond all previously known high water marks. The highest point reached by the Connecticut was three feet below that of the previous April and five feet below that of 1862. In Bellows Falls, the damage was comparatively light" (Hayes, 1907, p. 405).

SAXTONS RIVER IN VERMONT (OCTOBER)

Mr. A. H. Thompson of Saxtons River, Vt., and his brother made a mark for the 1938 flood in a mill in Saxtons River, Vt. Mr. Thompson reports that the 1938 mark was just below a mark for the 1869 flood, and both were three or four feet higher than the flood mark for 1927 and 1893 (oral communication, 1957). Mr. W. B. Gannon of the Geological Survey noted that there had been a dam at the location which was probably there during the flood of 1869 and was washed out during the 1938 flood. There was no information as to the height of the dam during the two great floods.

WEST RIVER IN VERMONT (OCTOBER)

“* * * a great flood that did much damage to the highways and bridges" (Booker, 1940).

Mr. Charles Taft, whose ancestors were among the original settlers of Dummerston, Vt., stated that his father had shown him the point to which the 1869 flood came around a culvert under Route 30. Mr. Taft does not believe that the water has ever come that high since. Mr. Taft said that he believed that the October 1869 flood was higher than either the 1927 or 1938 floods (oral communication, 1957).

NORTH RIVER IN MASSACHUSETTS (OCTOBER)

Shortly after the 1938 flood an elderly man, who had lived by the Kendall Mills all his life, mentioned that debris had to be removed from the first floor of the mill after the 1869 flood. The 1938 high water mark did not reach the first floor of the mill, which was built in 1860 (William Canon, oral communication, 1957). Controling features below the mill had not changed between the two floods. The mill dam is about one-half mile upstream from the mill. However, it is impossible to determine if the debris that came into the mill during the 1869 flood came 
from the overflow of the mill race which ran by the front of the mill or from the river which runs by the back of the mill.

Miss B. Read, who is librarian at Colrane, Mass., and who lives in Griswoldville, reported that her father, who built the house in which she grew up and which is on the bank of the river, told her that in 1869 he could have reached out the kitchen window and scooped up a cup of water from the river. Miss Read was quite certain that during the 1938 flood it would have been impossible to do this (oral communication, 1957).

WESTFIELD RIVER AT WESTFIELD, MASS. (OCTOBER)

"In 1869 and again in 1878, Westfield was visited by disastrous floods. After the first one, which caused property damage of over $\$ 100,000$, the dykes built after the flood of 1819 were raised higher than before. Yet the second [flood] was even more destructive and many houses and business blocks had to be rebuilt when the water subsided" (Johnson, Clifton, 1936, p. 752).

CONNECTYCUT RIVER IN MASSACHUSETTS AND CONNECTICUT (OCTOBER)

For relative flood stages, refer to page 85 .

SCANTIC RIVER AT SOMERSVILE, CONN. (OCTOBER)

"*** higher than was ever known before. *** At Broad Brook the sudden breaking away of a dam near Ellington sent a terrible flood which swept off the dam at that place" (Cole, 1888, p. 83).

FARMINGTON RIVER IN CONNECTICUT (OCTOBER)

"The flood in Collinsville was the most extensive and destructive known for many years. At 4 o'clock p.m., Monday the water had reached a higher point than at any time since the great ice flood of 1857" (Hartford Times, Oct. 5, 1869).

For relative flood stages at Collinsville, refer to page 84, this paper. PEQUABUCK RIVER AT FORESTVILLE, CONN. (OCTOBER)

"The flood of October was said to be two feet higher than at any time since 1854" (Hartford Times, Oct. 5. 1869).

QUINNIPIAC RIVER NEAR MERIDEN, CONN. (OCTOBER 4)

"Within the memory of the oldest inhabitant Meriden has never witnessed such a flood as visited this city today. *** Baldwin's new dam, east of Prattsville, gave way, and the water came rushing through the village, raising the stream from 5 to $6 \mathrm{ft} * * *$.

"The water was two foot higher than was ever known before" (Meriden Record, Oct. 6, 1869).

HOUSATONIC RIVER IN MASSACHUSETTS (OCTOBER)

"In Dalton, the dam at the paper mill of Crane \& Co., was carried away. It was built in 1809, and stood intact for 60 years" (Berkshire County Eagle, Oct. 7, 1869). 
"In this town [Pittsfield] no very great damage was done, but in North and South Adams, Williamstown, Cheshire, and other towns, the loss $* * *$ is very great" (Pittsfield Sun, Oct. 14, 1869).

Great Barrington: "The water in the streets ran like rivers ***. Stores on Main street had cellars flooded. *** at Van Deusenville $* * *$ the water rose to a foot in depth on the floor of the Wawbeck mill" (Berkshire Courier, Oct. 6, 1869).

BLACKBERRY RIVER AT CANAAN, CONN. (OCTOBER)

"North Canaan-The storm has done great damage ***. At East Canaan the channel of the river has changed and is running in the highway for a quarter of a mile" (Winsted Herald, Oct. 8, 1869).

STILL RIVER NEAR DANBURY, CONN. (OCTOBER)

"A flood such as has not occurred in fifteen or twenty years. In this immediate vicinity there was no great damage done" (Danbury Jeffersonian, Oct. 9, 1869).

FURNACE BROOK NEAR CORNWALL, CONN. (OCTOBER)

"*** rose higher on Monday than ever before, the Furnace Dam was carried away, $* * *$ West Cornwall is again torn to pieces" (Mountain County Herald, Oct. 8, 1869).

SHEPAUG RIVER NEAR ROXBURY, CONN. (OCTOBER)

"The fall of water is estimated at eight inches. In this county the results of the storm have been by no means as disastrous as those of the June [28] freshet ***" (Litchfield Enquirer, Oct. $7,1869)$.

housatonic RIVER at stevenson, ConN. (OCTOBER 4)

The river rose to a stage of 16 feet at the Birmingham river gage, when 160 feet of the great dam of the Housatonic Water Power Co., was swept away. The water was 6 inches higher than it had been during the past 3 years of construction even after the center of the dam washed out (Grover, 1937, p. 459).

For relative flood stages at Derby, Conn., refer to page 85 .

NAUGATUCK RIVER IN CONNECTICUT (OCTOBER)

"Wolcottville. We have escaped [the flood] almost entirely. The water was not as high into about three feet as on June 28 when it took everything before it" (Waterbury American, Oct. $8,1869)$.

At Seymour the flood reached a height of 15 feet, 9 inches (Grover, 1937, p. 459). 
1870

PENOBSCOT RIVER BASIN IN MAINE (FEBRUARY)

The Kenduskeag River was reported to be 8 feet over the highway near Six Mile Falls. No serious damage occurred along the Penobscot River itself (Grover, 1937, p. 440).

KENNEBEC RJVER IN HALLOWELL, MAINE (FEBRUARY 20)

For relative flood stages, refer to page 76 .

“*** The Kennebec River at Gardiner rose two feet higher than in 1869" (Grover, 1937, p. 443).

LITTLE ANDROSOOGGIN RIVER AT SOUTH PARIS, MAINE (FEBRUARY 17)

The flood brought water 3 to 4 feet deep over the Bacon Falls bridge floor (Lapham and Maxim, 1884, p. 199).

SACO RIVER IN MAINE (APRIL 11-22)

For relative flood stages at West Buxton, Maine, refer to page 77.

"The river stage at Saco, Maine, was 8.3 feet above the crest of the Bradbury Dam" (Grover, 1937, p. 448).

The Saco River was reported by the Concord [N.H.] Monitor of April 21, 1870, to be higher than at any time since 1827.

"We had the greatest freshet here [Saco, Maine] since 1843 and the river is probably higher now than then" (Concord [N.H.] Monitor, April 20, 1870).

CONTOOCOOK RIVER IN NEW HAMPSHIRE (APRIL)

The flood of April 1870 is mentioned in the Concord Monitor of June 18, 1883, as being one of four floods that were exceeded by the flood of 1869 .

MERRIMACK RIVER IN NEW HAMPSHIRE (APRIL)

The flood of April 20, 1870, at Concord, reached a stage of 19.9 feet on the city datum (Lyford, 1896, p. 14).

"The flood. It attained a height of two and one-half inches above the high water mark of April 20,1862, which is the highest spring freshet recorded in the shops [Concord Shops] since their erection, and the great depth of water at that time was occasioned in part by the Garvins Falls Dam which has since been opened at least part of the way. The water did not quite reach the October, 1869 mark, lacking three and one-half inches of it within the shop" (Concord Monitor, April 20, 1870).

At Manchester: "The water reached its highest point at midnight Wednesday the 20th. At this time Mr. S. B. Kidder had to revise his diary by saying the water was two and one-half inches higher than he had ever before known.

"** * The water dyed in use by the Amoskeag Manufacturing Company showed a stage on April 4, 1870 of 77.55 feet, and on April 20, 1870 of 81.4 feet, the latter height being the highest 710-949-64-4 
recorded since the records began in 1867" (Browne, 1915, p. 180, 181).

For relative flood heights at the Amoskeag Mills, refer to page 79.

MERRIMACK RIVER IN MASSACHUSETTS (APRIL 21)

At Lowell: For relative flood discharges, refer to page 13, and for relative flood heights over Pawtucket Dam, refer to page 80.

At Lawrence: For relative flood stages, refer to page 81 .

1874

STILL RIVER HEAR WINSTED, CONN. (JANUARY 9)

"The deluge $* * *$ although its utmost height was 15 inches less than that of June 1869, was nevertheless a deluge that 'trifled former knowings'" (Winsted Herald, Jan. 9, 1874).

FARMINGTON RIVER IN CONNECTICUT (JANUARY)

"Our Collinsville correspondent writes $* * *$ a great flood in the Farmington river-one of the greatest in fifty years [Jan. 26, 1839]. The works of the Collins Co. were of course stopped, as the water was 6 feet deep and more in some shops" (Hartford Courant, Jan. 10, 1874).

STILL"RIVER NEAR LANESVILle, CONN. (JANUARY)

"Bethel, Jan. 8th. Severely damaging storm and freshet. *** the dam which has stood firm for perhaps a hundred years gave way and was swept down to the large factory" (Bridgeport Standard, Jan. 9, 1874).

"Since the fall flood of 1853 and the spring freshet of 1954 we have had, according to the testimony of judicious observers, nothing approaching that which on Wednesday and Thursday, the 7th and 8th, visited this town" (Danbury News, Jan. 14, 1874).

HOUSATONIC RIVER AT STEVENSON, CONN. (JANUARY 7)

"The Housatonic Dam-The water rolls over it eight feet and four inches deep.

"This freshet is the highest experienced in Derby for twenty years" (Bridgeport Standard, Jan. 9, 1874).

For relative flood stages at Derby, refer to page 85 .

The river rose to a stage of 17 feet $4 \frac{1}{2}$ inches at Birmingham river gage (Grover, 1937, p. 459).

NAUGATUCK RIVER NEAR NAUGATUCK, CONN. (JANUARY)

"The Naugatuck river rose rapidly $* * *$ The water came up almost even with the depot platform ***" (Waterbury American, Jan. 8, 1874). 
PEQUABUCK RIVER IN CONNECTICUT (AUGUST)

"Bridges are carried away, streets are gullied, portions of the town have quite a ruined appearance" (Waterbury American, Aug. 20, 1875).

STILL RIVER NEAR DANBURY, CONN. (AUGUST)

"Since the great flood of 1854 , our 'oldest inhabitant' has been in the habit of comparing subsequent floods with that one. But now the old standard has been swept away, and he abandons the memory of 1854, and gauges by the great rain of 1875 .

" *** the highest flood from natural causes we have had since the above mentioned date.

"In and about Danbury the waters were very high. Loss to the town by bridges and roads being washed away is considerable" (Danbury News, Aug. 25, 1875).

POMPERAUG RIVER NEAR WOODBURY, CONN. (AUGUST)

"Five of the principal bridges in Woodbury were carried off * * *" (Waterbury American, Aug. 19, 1875).

HOUSATONIC RIVER AT DERBY, CONN. (AUGUST 19) $459)$.

A stage of 11 feet 6 inches was recorded (Grover, 1937, p. NAUGATUCK RIVER IN CONNECTICUT (AUGUST)

"In and around Waterville the damage is immense" (Waterbury American, Aug. 19, 1875).

1876

BRANCH RIVER AT FORESTDALE, R.I. (MARCH)

The flood of March 1876 was said to be the greatest flood ever to be recorded in this vicinity until 1886. (From files of Geological Survey, Boston, Mass.)

BLACKSTONE RIVER AT WOONSOCKET, R.I. (MARCH)

"*** has rarely if ever, attained such a height. It was four or five inches higher in the Haircloth Mill than in 1867 where it is now 191/2 inches on the floor" (Providence Journal, March 23, 27, 1876).

WOONASQUATUCKET RIVER AT CENTERDALE, R.I. (MARCH)

"The damage by water in this vicinity was considerable. The highest water since $1867 * * *$ " (Providence Journal, March 23, $27,1876)$.

NATCHAUG RIVER AT WILLIMANTIC, CONN. (MARCH)

The Southbridge Journal of March 30 stated that the flood of March 30 was the highest in years.

SHETUCKET RIVER NEAR WILLIMANTIC, CONN. (MARCH)

"The flood of Saturday [Mar. 25] has done large damage in Willimantic and vicinity. At 6 o'clock a.m. - the biggest freshet ever known here began" (Hartford Times, Mar. 27, 1876). 
“*** Sunday March 26, 1876, occurred the memorable freshet, which an old resident said, was $13^{\prime \prime}$ higher than that of 1857 and $5^{\prime \prime}$ higher than that of 1807" (Norwich Bulletin, Feb. 15, 1886).

"In that flood [1876] the head on the dam on the Shetucket River at Greenville, Conn., was reported as 12 to 14 feet. The census report states that the spillway of this dam was 326 feet long and that in 1881 work was started on a new dam (presumably the present one) about 1,200 feet below the old one, with the same crest elevation and a length of 400 feet.

"The crest length of the present dam was measured in 1936 as 401 feet. The head on this dam was 11.1 feet on March 12, 1936, and probably resulted from the normal runoff from the drainage basin being augmented by the failure of dams upstream. It is probable that the maximum head on the dam at the time of the maximum normal runoff from the drainage basin on March 19, 1936, was about 10.5 feet. From this information it appears that the discharge at Greenville in March 1876 was as much or more than that of March, 1936" (Grover, 1937, p. 451).

"On March 26, 1876, it is said that there was 10 feet of water over the Taftville Dam * * *."

"The maximum discharge on the Shetucket River above its junction with the Quinebaug River of which any record has been found, occurred in the vicinity of Baltic during the 1876 storm and is variously estimated at 65 to $100 \mathrm{cfsm}$ [cubic feet per second per square mile]. At Norwich, below the mouth of the Quinebaug River, the same flood is estimated at 35 to $45 \mathrm{cfsm}$, which indicates that the flood runoff per square mile on the Quinebaug was much less than the Shetucket" (House Document 644, 71st Congress, 3rd Session, p. 12).

QUINEBAUG RIVER IN MASSACHUSETTS (MARCH)

"The Hamilton Woolen Company's teams and men were watching and working all day. Never before was the river known to be so high, and it was a grand sight to see the five feet of fall over the 100-ft rollway at the big pond" (Southbridge Journal, Mar. 30, 1876).

FRENCH RIVER AT WEBSTER, MASS. (MARCH)

“*** Water at the Power building on last Tuesday was four feet above high water mark" (Webster Times, Mar. 25, 1876).

"The Flood.- $* * *$ The lower part of the town, which is on the banks of the French river was inundated, and the river had swollen in dimensions, having risen several feet" (Webster Times, Apr. 1, 1876). 
YANTIC RIVER AT YANTIC, CONN. (MARCH)

"** * the dam and bridge at Fitchville are gone and the mill is said to be undermined and in danger" (Meriden Republican, Mar. 27, 1876).

CONNECTICUT RIVER ABOVE DALTON, N.H. (SPRING)

"We come now to what probably was the greatest rise of water ever known in this section. *** as soon as the water had passed the mark of its previous highest altitude, the great river seemed to feel satisfied, and slowly the waters receded ***" (Benton, 1886, p. 113).

WELLS RIVER AT WELLS RIVER, VT. (DATE UNKNOWN)

A flood in 1876 was said to have equaled a flood mark set in the flood of 1807 (Wells, 1902).

CONNECTICUT RIVER NEAR NEWBURY, VT. (DATE UNKNOWN)

For comparative flood heights, see oral communication by Judge Brock, page 70.

"*** a flood in which the river rose about 8 inches above the highest mark ever reached. The water was six inches deep on the kitchen floor of the house in which Mr. Charles C. Scales now lives, on the upper meadow" (Wells, 1902, p. 259).

\section{7}

SHETUCKET RIVER AT NORWICH, CONN. (MARCH 27)

"On Mar. 27, 1877, a storage reservoir 5 miles above Stafford Springs on a branch of the Willimantic River gave way carrying with it all eight dams on the branch below as well as the bridges * * *" (Report of the Chief of Engineers on Thames River, Conn., House Document 644, 71st Congress, 3rd Session).

1878

BAKER RIVER IN NEW HAMPSHIRE (DECEMBER)

"Another well-remembered serious freshet was im December, 1878. The river rose rapidly unto a great height nearly as high as in 1869" (Plummer, 1930, p. 314).

PEMIGEWASSET RIVER IN NEW HAMPSHIRE (DECEMBER)

Mr. Harry Johnson of Plymouth, N.H., described the flood of 1878 as told to him by his father, the flood having occurred when Mr. Johnson was about 1 year old. Mr. Johnson's father told him about riding a boat across the intervale at Plymouth from his blacksmith shop at the east side of the intervale, and rowing into the old covered bridge (oral communication, 1957).

"The great body of snow on the ground, combined with the rain to raise the water nearly as high as the great freshet of $1869^{\prime \prime}$ (Concord Monitor, Dec. 12, 1878).

Bristol: " *** the streams were at flood height. The Pemigewasset was within three feet of the top of the wall at the 
depot, and the river was filled with debris and driftwood. At the foot of Newfound Lake a stone set to mark the height of the water in 1843 was covered to a depth of ten inches" (Musgrove, 1904, p. 474).

CONTOOCOOK RIVER IN NEW HAMPSHIRE (DECEMBER)

"The Contoocook River is swollen to height not reached since the great freshet of October, 1869" (Concord Monitor, Dec. 12, 1878).

MERRIMACK RIVER NEAR CONCORD, N.H. (DECEMBER)

"The water reached its highest point early this morning [Wednesday], the gage at the Concord Shop showing that the water reached within one inch of the height it attained in the month of October, 1869***" (Concord Monitor, Dec. 12, 1878).

At Concord a stage of 20.09 feet on the city datum was reached (Lyford, 1896, p. 14).

SOUHEGAN RIVER AT MILFORD, N.H. (DECEMBER 10)

"The water $* * *$ has reached the highest point attained in the freshet of 1869, doing considerable damage" (Pittsfield Sun, Dec. 11, 1878).

NASHUA RIVER IN MASSACHUSETTS (DECEMBER)

"The heavy rain of yesterday flooded everything. Monoosnock Brook overflowed its banks in several places. *** It is reported that the water in Monoosnock Brook has never been known to be so high, before by fifteen inches" (Leominster Enterprise, Dec. 11, 1878).

MERRIMACK RIVER AT LOWELl, MASS. (DECEMBER 12)

The height of the water at Pawtucket Dam on December 12, 1878, was 10 feet $8 \frac{1}{2}$ inches (Francis, 1885).

For relative flood discharges at Pawtucket Falls, refer to page 13.

MIDDLE BRANCH WESTFIELD RIVER IN MASSACHUSETTS (DECEMBER)

For comparative flood information see oral communication by Mr. E. Eastman, page 90.

WESTFIELD RIVER IN MASSACHUSETTS (DECEMBER)

The 1878 peak flow at West Springfield, Mass., was estimated to be $46,000 \mathrm{cfs}$; in 1927 the flow was estimated to be $38,000 \mathrm{cfs}$. The peak flow of the 1869 flood was between the two (Boston Soc. Civil Engineers, 1930).

"A special committee appointed by the town [Westfield, Mass.] engaged Mr. Hiram F. Mills as consulting engineer. *** Mr. Mills estimated a maximum flow of 53,000 cubic feet per second at Woronoco, or about 150 second feet per square mile. At the Agawam Dam at Mittinesque the flow was 46,000 cubic 
feet per second or 90 second feet per square mile $* * *$ in the 1878 flood the rise on Mr. H. E. Stanton's 260-foot dam on the east branch at Huntington was between 12 and 13 feet." (Note made in margin of book: "Call it $12.5 \mathrm{ft}$., $225 \mathrm{sq}$. mi., drainage area, $Q=38,000 \pm$ which equals $170 \mathrm{cfsm}$ ") (Massachusetts Comm: on Waterways and Public Lands, 1918, p. 124).

"In 1869 and again in 1878, Westfield was visited by disastrous floods. After the first one, which caused property damage of over $\$ 100,000$, the dykes built after the flood of 1819 were raised higher than before. Yet the second one was even more destructive and many homes and business blocks had to be rebuilt when the water subsided" (Johnson, Clifton, 1936).

FARMINGTON RIVER IN CONNECTICUT (DECEMBER)

"Pleasant Valley. Never before have we witnessed such high water as occurred here last Tuesday. $* * *$ Serious damage was done to the Episcopal Chapel [built around 1846], also on the island; the water marks on the seats, organ and stove, found to be 14 inches above the floor.

"New Hartford. In more than forty years there has not been such a torrent of water pouring down the Farmington River as upon Tuesday night. *** The water in Greenwood's Pond *** where it makes its leap over the dam, the tops of the abutments were almost reached" (Winsted Herald, Dec. 13, 1878).

For relative flood stages at Collinsville, refer to page 84 .

STILL RIVER NEAR LANESVILLE, CONN. (DECEMBER)

"*** raising them [the streams] to a height unknown since the Wooster Monument flood in April, 1854. *** The water at the Hull and Belden Co.'s shops never came so high before" (Danbury News, Dec. 11, 1878).

NAUGATUCK RIVER IN CONNECTICUT (DECEMBER)

The flood of December 10 was described as the most severe for a number of years at Seymour, its peak flow coming to within 6 inches of the flood of January 8, 1874, and having a stage at Seymour of 17 feet and 1 inch (Wolcottville Register, Dec. 14, 1878).

hoUSATONIC RIVER AT DERBY, CONN. (DECEMBER)

A stage of 15 feet and 9 inches was recorded (Grover, 1937, p. 459).

QUINNIPIAC RIVER IN CONNECTICUT (FEBRUART)

"The Quinnipiac River is flooded to a greater extent than at any time for the past ten years in Southington.

"Wallingford. Last evening the Quinnipiac River was higher than before in many years and the water was rushing over the 
Community dam four feet in depth" (Meriden Republican, Feb. 13, 1882).

ASHUELOT RIVER NEAR KEENE, N.H. (SEPTEMBER 24)

"A freshet, highest for fifteen years [since the flood of October, 1869] ***" (Griffin, 1904, p. 686).

FARMINGTON RIVER IN CONNECTICUT (SEPTEMBER)

"Collinsville. The severe rains of last week raised the Farmington River to the greatest flood since 1878" (New Hartford Tribune, Sept. 29, 1882).

HOUSATONIC RIVER AT DERBY, CONN. (SEPTEMBER)

For relative flood stages, refer to page 86 .

1886

The storm of February 11 to 14,1886 is one of the 12 great storms in New England. "February 11 to 14, 1886, in southeastern New England, lasting abour 48 hours. Rainfall 5 to 8 inches, but owing to deep snow, which melted, about 2 inches more of water was released" (Kinnison, 1929, p. 84).

IPSWICH RIVER NEAR IPSWICH, MASS. (FEBRUARY)

"The boarding house of Roswell Ford, was completely surrounded by water, something which never before happened" (Ipswich Chronicle, Feb. 20, 1886).

Mr. Bowen of 3 Summer Street, Ipswich, 84 years old, who wrote a brief, folksy history of Ipswich reports that the water during the 1886 flood was up to the sidewalk on the river side of Market Street, but it did not get over the street. Mr. Bowen did not think that the flood of 1936 compared with that of 1886 (oral communication, 1957).

For comparative flood information, see page 81 .

ABERJONA RIVER NEAR WINCHESTER, MASS. (FEBRUARY)

"The amount of rainfall $* * *$ as measured by Mr. Luther $\mathrm{R}$. Symnes, was 5.5 inches; which, added to the melted snow, rendered the amount to be discharged by the Aberjona equivalent, in his judgment, to be about 8.5 inches.

"This amount from a watershed of 17,760 acres can be estimated by the curious, $* * *$ that 'the yield of the Mystic watershed [from the 12th to the $17 \mathrm{th}$ ], was 2,060,000,000 gallons, *** at the Mystic Dam *** six hundred and fifty million gallons were wasted in the overflow of February 13.'

“*** yet the water in the streets at the center of Winchester was not so high as in the flood of February 16, 1855.

"It may seem difficult of comprehension that a rainfall of a single night $* * *$ as that of February 15, 1955, with only six inches of snow upon the surface of the ice $* * *$ should have produced a higher flood than the conditions named above affect- 
ing the recent one; but the fact of the ice dam named, and additional facts relating to the position of the Pleasant Street bridge, and the changes in railway embankments, and the absence of that canal aquaduct sufficiently account for it" (Winchester Record, v. 2, p. 387, 532).

CHaRLes River in MassachusetTS (FEbrUary)

Natick. "The water in the river rose quite rapidly, and the backwater rose much faster, as in former freshets, but this time far exceeded all previous records, as it is believed to have been fourteen inches higher than the crest of the dams, and only about sixteen inches lower than the surface of the mill pond, while the volume of water passing over the dam was calculated to thirty inches in depth. $* * *$ The great point of interest was on the cape, where the rising water reached the windows. As a flood had never before come upon that site since the houses had been erected there, no thought of being driven from their homes had occurred to them; therefore, nothing had been removed from the houses until after boats had become a necessary means of conveyance" (Natick Citizen, Feb. 17, 1886).

Miss Mable A. Parmenter, who has lived all her life on the "cape" referred to above and is custodian of the South Natick Historical Society, reported that in the celler of her home are marks of recent floods and that the flood of 1886 was at least 2 feet higher than any mark made for recent floods (oral communication, 1957).

"The flood at Andrew Morris' mill was the greatest ever known. $* * *$ The water reached the highest point known in forty years experience at the mills" (Natick Bulletin, Feb. 19, 1886).

Dr. Arthur M. Worthington of Dedham, head of the Dedham Historical Society, was 16 years old at the time of the 1886 flood and was able to describe it vividly. He states that he is quite certain that the waters of the 1886 flood were higher than the arches of several bridges in town, but that the 1955 flood did not reach the top of these same arches (oral communication, 1957).

"At Newton pumping station the water invaded the lower engine room while the river swept along at a height of five feet and a half above the filtering basin.

“**** and the maximum flow of the stream during the highest known freshet, namely, that of February 1886, was about 4.900 cubic feet per second at the dam of the Boston Manufacturing Company at Waltham, and by estimation 5,200 cubic feet per 
second at the Watertown Dam" (Massachusetts Comm. Waterways and Public Lands, 1918, p. 239).

BLACKSTONE RIVER AT WOONSOCKET, R.I. (FEBRUARY 13)

"The water rose to a greater height in the river Saturday morning than ever before in the memory of man now living. The great flood on March 1876 has always been alluded to as the greatest on the river, but yesterday the water was two feet and four inches higher than at that time. There are four feet four inches of water in the Haircloth Mill floor. Maximum discharge was 21,000 cubic feet per second. There was eleven inches of rainfall. Flood height at Valley Falls Dam was 60.07 and at King Philip Finishing Co. building 19 it was 60.50" (Williams, 1955).

WOONASQUATUCKET RIVER AT CENTERDALE, R.I. (FEBRUART 13)

At Brayton Bridge the water was higher than has been recorded at this point at any time within the last 40 years. The dam at Dyerville gave way (from files of the Geological Survey, Boston, Mass.).

PAWCATUCK RIVEr at WESterly, R.I. (February)

The flood was $2 \frac{1}{2}$ feet higher than any time since 1836 . The highest water previous to 1886 was in 1784 , at which time the water was one foot lower than 1886 (Westerly Sun, March 17, 1953).

WOOD RIVER AT HOPE VALLEY, R.I. (FEBRUARY)

This flood reached a gage height of at least 12.4 feet. It exceeded the great flood of 1843 , but was not as disastrous (from files of the Geological Survey, Boston, Mass.).

WILLIMANTIC AND NATCHAUG RIVERS NEAR WILLIMANTIC, R.I. (FEBRUARY)

"The heavy rain Friday caused a rise of several feet in the Willimantic and Natchaug Rivers, only less by 6 inches than the great flood of March 26, 1876" (Grover, 1937).

"The water did not rise as high as it did during the great storm of Oct. 4, $1869 * * *$ * (Willimantic Chronicle, Feb. 17, 1886).

SHETUCKET RIVER NEAR WILLIMANTIC, CONN. (FEBRUARY)

"The volume of water exceeded that of 1876 from reports from the surrounding country. $* * *$ Seven feet of water over Baltic dam [a log dam built in 1876]. It has a rollway of 515 feet" (Norwich Bulletin, Feb. 15, 1886).

LITTLE RIVER NEAR HANOVER, CONN. (FEBRUART)

"The water did not rise as high [in Willimantic] as it did during the great storm of Oct. 4, 1869 [or other] former occasions, but in New London County the rise was unprecedented" (Willimantic Chronicle, Feb. 17, 1886). 
QUINEBAUG RIVER IN CONNECTICUT (FEBRUARY)

"At West Dudley *** at noon Saturday close watch was begun at the dam as the river was within a few inches of the height reached during the freshet of ten years ago and was rapidly increasing while the ice threatened to break up at any time" (Southbridge Journal, Feb. 19, 1886).

"Pomfret Landing. We have the testimony of the oldest inhabitants that the flood or freshet in the valley of the Quinebaug River and other streams occurring on the 13th and 14th instant was the greatest ever known by them" (Willimantic Chronicle, Feb. 24, 1886).

"No floods from that of Feb. 11-13, 1886 to 1933 were as big as the 1886 flood on the Quinebaug River" (Norwich Bulletin, Feb. 14, 1933).

SHETUCKET AND YANTIC RIVERS IN CONNECTICUT (FEBRUARY)

"Norwich, Feb. 13, the flood prevailing here exceeds the memorable freshet of 1876" (Providence Journal, Feb. 13, 1886).

"The Shetucket and Yantic flooded Norwich Saturday, rising nearly 30 feet in 24 hours and reached the highest point ever known" (New Haven Register, Feb. 15, 1886).

1887

ST. JOHN RIVER NEAR FORT KENT, MAINE (MAY)

"The St. John at Woodstock, higher than has been known since 1854" (Aroostook Times, May 12, 1887).

Mr. Joe Kelley, age 84, life-long resident of Dickey, Maine, which is about 40 miles upstream from Fort Kent, reports that the highest flow ever recalled by residents in the area occurred in June, 1887 [perhaps May 12 flood], and that the flood of 1896, which was caused by ice jams, was the next highest flood on the St. John River (oral communication, 1957).

PENOBSCOT RIVER IN MAINe (MaY)

"Where the track of the M.C.R.R. runs between Bangor and Vanceboro the water has covered the rails to a depth of several feet" (Aroostook Times, May 5, 1887).

"It is said there has not been such a freshet as we have experienced this spring since 1854" (Aroostook Times, May 12, 1887).

KENNEBEC RIVER AT WINSLOW, MAINE (APRIL 30)

For relative flood stages, refer to page 76 .

1891

PARK RIVER IN CONNECTICUT (JANUARY)

"The big storm and thaw made the Park river rise at an unprecedented rate. At 10 o'clock it had reached a higher point 
than it is remembered to have attained before" (Waterbury American, Jan. 23, 1891).

QUINNIPIAC RIVER NEAR WALLINGFORD, CONN. (JANUARY)

"The highest stage ever known occurred at Plantsville, 16 feet at the Main Street bridge" (Waterbury American, Jan. 23, 1891). STILL RIVER NEAR LANESVILLE, CONN. (JANUARY)

"At corner of West and Montgomery streets the water reached to the second-story windows. ${ }^{* * *}$ All the houses on South William Street are flooded to a depth of over five feet" (Waterbury American, Jan. 23, 1891).

HOUSATONIC RIVER NEAR STEVENSON, CONN. (JANUARY)

"The Housatonic Dam was badly damaged by an ice jam. The water was twelve feet over the crest of the dam, probably obstructed by ice. The greatest flood Derby and Shelton ever did, or ever will, witness" (Derby Sentinel, May 12, 1951). 1895

PISCATAQUIS RIVER IN MAINE (APRIL)

Stage was 8 feet above normal. There was no serious damage (Grover, 1937, p. 440).

KENNEBEC RIVER AT WATERVILLE, MAINE (APRIL 15)

For relative flood discharges, refer to page 63.

ANDROSCOGGIN RIVER IN RUMFORD, MAINE (APRIL 15)

For relative flood discharges, refer to page 76.

LITTLE ANDROSCOGGIN RIVER NEAR SOUTH PARIS, MAINE (APRIL)

The flood of April at Norway was said to be the highest since 1869 (from files of the Geological Survey in Augusta, Maine).

SACO RIVER IN MAINE (APRIL 17)

For relative flood stages at West Buxton, Maine, refer to page 77.

A stage of 10.5 feet above the crest of the dam at Union Falls was reached. Damages in the Saco River basin were not serious. At North Conway, N.H., it was called the worst flood since 1869 (Grover, 1937, p. 447, 448).

The April flood was the highest ever know at Hiram. It was above the 1870 mark in Saco on the 16th (from files of the Geological Survey in Augusta, Maine).

PEMIGeWasset RIVER AT PLymouth, N.H. (APRIL)

A mark designating the height of the 1895 flood was 6 inches higher than a railroad spike marking the flood of Oct. 4, 1869. However, the flood of 1895 was exceeded by the floods of 1927 and 1936 at that point (Grover, 1937, p. 449).

PemigeWasset River at bristol, N.H. (APRiL)

"The Pemigewasset was a roaring torrent at the depot within two feet of the top of the wall. In some places this freshet registered higher than that of 1869 " (Musgrove, 1904, p. 487). 
CONTOOCOOK RIVER IN CONTOOCOOK, N.H. (DATE UNKNOWN)

For comparative flood heights, see oral communication by Mr. A. Huntoon, page 77.

MERRIMACK RIVER NEAR CONCORD, N.H. (DATE UNKNOWN)

"This morning the water was nearly a foot deep in the basement of the Concord and Montreal Railroad Shops ***. The last time the water rose to a height sufficient to inundate the shop, was in 1884. The freshet of that year brought the water to a height five inches greater than that of yesterday and today. On October 5, 1869 the highest point ever touched on the railroad water mark was reached. $* * *$ The river was higher by fouf and one-half feet than it was at the highest point last night" (Concord Monitor).

MERRIMACK RIVER NEAR MANCHESTER, N.H. (APRIL 15)

For relative flood stages refer to page 79 .

"*** the water was flowing ten feet and six inches over the dam [Amoskeag Dam]. This exceeded the height of the water during the famous freshet of 1878 when it rose nine feet and four inches" (Browne, 1915, p. 181).

MERRIMACK RIVER AT LOWELL, MASS. (DATE UNKNOWN)

For relative flood discharges, refer to page 13, and for relative flood heights over Pawtucket Dam, to page 80 .

CONNECTICUT RIVER NEAR NORTH WALPOLE, VT. (APRIL)

"The gauge at the dam showed that 18.9 feet were going over for about an hour between 5 and 6 o'clock Saturday morning [Apr. 3, 1913] and the record of 1895 showed a mark of 19.4 feet.

"It is generally believed that the flood of 1862 was the greatest in history and the flood of 1895 is ranked second. The printed accounts however, do not indicate that there was much difference between the flood of 1895 and 1869, at both times the tunnel was banked and the railroad tracks were covered with water" (Bellows Falls Times, Apr. 4, 1913).

For comparative flood information, see statement referring to flood of 1895 on page 21.

CONNECTICUT RIVER AT VERNON, VT. (APRIL)

“*** the water in the Connecticut River here Monday was undoubtedly several inches higher than in 1869 and from one foot to two feet lower than in 1862. At the latter time the water swept through the buildings at the Fort Dummer Farm, badly damaging the contents of the house. This time the water only reached the buildings" (Vermont Phoenix, Apr. 19, 1895).

ASHUELOT RIVER NEAR GILSUM, N.H. (APRIL)

"April 9, the water in the Fairfield reservoir escaped, doing considerable damage. Water rose to an unusual height in the Ashuelot and Beaver brook valleys, old residents agreeing that 
there had not been such a flood for twenty-four years, and by the night of the 14th, Beaver brook was higher than ever remembered before by almost a foot, and the Ashuelot reached the high water mark" (Griffin, 1904, p. 697).

CONNECTICUT RIVER IN MASSACHUSETTS AND CONNECTICUT (APRIL)

For relative flood stages, refer to page 85 .

1896

HOUSATONIC RIVER NEAR GAYLORDSVILLE, CONN. (FEBRUART)

"New Milford. The worst storm and deluge by water since 1854. The roads are badly washed and bridges by the score carried away or moved from their foundations" (Newtown Bee, Feb. 14, 1896).

STILL RIVER NEAR LANESVILLE, CONN. (FEBRUARY)

"The shop is flooded 18 inches. The third time it was flooded in 30 years. Bridges were washed away" (Newtown Bee, Mar. $6,1896)$.

SHEPAUG RIVER IN CONNECTICUT (FEBRUARY)

"Roxbury. The severe rainstorm of Thursday caused much damage" (New Milford Gazette, Feb. 14, 1896).

housatonic RIVER AT STEVENSON, CONN. (FEBRUARY 7)

At the Housatonic Dam it was 6 feet 4 inches over the crest, the greatest stage ever reached between 1869 and 1900 (from files of the Geological Survey, Hartford, Conn.).

NAUGATUCK RIVER AT NAUGATUCK, CONN. (FEBRUARY 7)

"The stage at Seymour was 16 feet and 5 inches" (Waterbury American, Feb. 7, 1896).

"From a reliable record kept at the store of James O. May, the flood last night was 18 inches higher than the freshet in January 1891 and that flood was higher than any for eight years previous" (Waterbury American, Feb. 7, 1896).

KENNEBEC RIVER IN MAINE (MARCH 2)

For relative flood discharges at Waterville, refer to page 63, and for relative flood stages at Hallowell, to page 76 .

ANDROSCOGGIN RIVER IN MAINE (MARCH 2)

For relative flood discharges at Rumford, refer to page 76 .

"The most destructive *** previous to that of March 1936 $* * *$. The flow $* * *$ at Lewiston was estimated at 65,000 second-feet, the highest since the beginning of the records in 1850" (Grover, 1937, p. 446).

SACO RIVER IN MAINE (MARCH 2)

For relative flood stages at West Buxton, refer to page 77.

"The flood of Mar. 2, 1896 was two feet higher than the previous high water at Brownfield, and four feet above the floor in the 
Garland Building in Saco" (from files of the Geological Survey, Augusta, Maine).

"The discharge of the Saco River at Biddeford was approximately 40,000 second-feet $* * *$. This was the second largest flood on record at Biddeford. The Saco River reached a stage of 9.75 feet above the crest of Bradbury Dam in Saco" (Grover, 1937, p. 448).

COCHECO RIVER NEAR DOVER, N.H. (MARCH)

"The city of Dover is being visited by one of the most destructive floods $* * *$ in its history. $* * *$ The water at the dam is 108 inches above the dam and the highest point ever reached previously was 59 inches" (Concord Monitor, Mar. 2, 1896).

PEMIGEWASSET RIVER AT BRISTOL, N.H. (MARCH)

"The Pemigewasset did not reach the height of the freshet of 1895 by a foot, but south of there the records exceeded that" (Musgrove, 1904, p. 488).

CONTOOCOOK RIVER AT PETERBORO, N.H. (DATE UNKNOWN)

The flood of 1896 was described as the worst in history (Smith, 1896, p. 15).

MERRIMACK RIVER AT CONCORD, N.H. (DATE UNKNOWN)

Relative flood heights of the 1896 and 1895 floods, referenced to the city datum of Concord, were 21.53 feet and 21.65 feet, respectively (Lyford, 1896, p. 14).

SUNCOOK RIVER AT SUNCOOK, N.H. (MARCH)

"At nine this morning the river was two feet higher than one year ago" (Concord Monitor, Mar. 2, 1896).

PisCATAqUOG RIVER IN NEW HAMPSHIRE (MARCH)

"The Piscataquog River rose to unprecedented volume and the water at Kelly's Falls rose to $8 \frac{1}{2}$ feet which was nearly 3 feet higher than in 1895" (Browne, 1915, p. 184,185).

MERRIMACK RIVER NEAR MANCHESTER, N.H. (MARCH)

For relative flood stages at Manchester, refer to page 79 . SOUHEGAN RIVER AT MILFORD, N.H.

A great freshet reached the highest point since 1869 (Concord Monitor, Mar. 2, 1896).

MerRimack RIVER at NASHUa, N.h. (MARCh)

"On March 2, 1896 the Merrimack was higher at this point than it has been since $1852 * * *$ " (Webster, 1913, p. 396).

MERRIMACK RIVER IN MASSACHUSETTS (MARCH 3)

For relative flood discharges at Lowell, refer to page 13 , and for relative flood heights over Pawtucket Dam, to page 80 .

The altitude of the flood of Mar. 3, 1896, at Lowell was 94.83 
feet (flood files in the office of the Proprietors of the Locks and Canals on the Merrimack River.

For relative flood stages at Lawrence, refer to page 81 .

PASSUMPSIC AND MOOSE RIVERS IN VERMONT (MARCH)

"On the first day of March this year was the biggest ice pack ever known in the town" (Fairbanks, 1912, p. 518).

CONNECTICUT RIVER AT SOUTH NEWBURY, VT. (DATE UNKNOWN)

For comparative flood heights, see oral communication by Judge Brock, page 70.

OTTAUQUECHEE RIVER IN VERMONT (MARCH)

A flood of Mar. 1-3, 1896, was described as having the same peak flow as the 1895 flood, which in turn was described as having a somewhat lower peak than one or two previous floods, (newspaper files of historic floods on the Ottauquechee River in the Woodstock library).

STILL AND MAD RIVERS NEAR ROBERTSVILLE, CONN. (MARCH)

"There was much water in Winsted. Mad River overflowed its banks in the center of town and Main St. was flooded in some places to a depth of four feet" (Torrington Register, Mar. 6, 1896).

FARMINGTON RIVER IN CONNECTICUT (MARCH)

For relative flood stages at Collinsville, refer to page 84 .

CONNECTICUT RIVER IN MASSACHUSETTS AND CONNECTICUT (MARCH)

For relative flood stages, refer to page 85 .

QUINNIPIAC RIVER AT WALLINGFORD, CONN. (MARCH 1)

“*** four feet over the community dam at Wallingford

***" (Meriden Journal, Nov. 2, 1896).

housatonic RIVER NEAR DALTON, MASS. (MARCH)

"Dalton. High water line on Sunday when the water reached four feet above the level of Weston's dam" (Pittsfield Sun, Mar. $5,1806)$.

HOUSATONIC RIVER NEAR GAYLORDSVILLE, CONN. (MARCH)

"Kent. * * * the waters in all the streams higher than it has been for a good many years" (Newtown Bee, Mar. 6, 1896).

STILL RIVER NEAR LANESVILLE, CONN. (MARCH)

"On Feb. 29, 1896 two bridges were carried off" (Newtown Bee, Mar. 6, 1896).

SHEPAUG RIVER IN CONNECTICUT (MARCH)

"Woodville. The rain ***doing more damage than before in years, taking the bridge near Charles Beemans that, with great cakes of ice, came rushing down, tearing away all the stone work of the mill dam" (New Milford Gazette, Mar. 6, 1896). 
"Washington. The flood of Saturday did considerable damage in this vicinity [more than on Feb. 13]" (Newtown Bee, Mar. 6, 1896).

NAUGATUCK RIVER IN CONNECTICUT (MARCH)

"Torrington, Mar. 2. ***it being about 30 years since the waters have stood at the height reached on that day. ${ }^{*} * *$ The water reached its highest point $* * *$ when it touched the mark reached by the big storm of June 1867" (Waterbury American, Mar. 2, 1896).

"Thomaston, Mar. 2. The river was several inches higher than at the other flood, and it is said that it was higher than ever known here before" (Waterbury American, Mar. 2, 1896).

"In Waterbury *** the New England station at the height of the flood was under water to a depth of 14 inches, and the freight yard was covered to a corresponding depth" (Torrington Register, Mar. 6, 1896).

"Naugatuck had the highest flood since $1854 * * *$ " (Torrington Register, Mar. 6, 1896).

"Naugatuck. ${ }^{* * *}$ The record kept at the drug store of Mr. James O. May showed that at 5 a.m. the water was a full 10 inches higher than on February 6 last, so that this flood is the highest since Apr. 30, 1854" (Waterbury American, Mar. 2, 1896).

\section{7}

NEWFOUND LAKE IN NEW HAMPSHIRE (DATE UNKNOWN)

"A stone in the highway to mark the high water of 1843 , was covered 2 to 3 inches deep" (Musgrove, 1904, p. 488).

ASHUELOT RIVER IN NEW HAMPSHIRE (MAY 14)

"The dam at Wilson Pond, West Keene, went out, freeing 30 acres of water, bridge and abutments washed away ***” (Griffin, 1904 p. 699).

NASHUA RIVER NEAR FITCHBURG, MASS. (JULY)

"Water damage at Fitchburg. Water in the pond back of the Cushing Grain Mill on Laurel Street was unusually high, being about a foot above water mark" (Leominster Enterprise, July 9, 1897).

SLEEPERS RIVER NEAR ST. JOHNSBURY, VT. (JULY 24)

“*** the foundry bridge was swept off and water ran four feet deep through the blacksmith and machine shops and the foundries depositing generous layers of mud. Four bridges went off on the Sleepers River ***" (Fairbanks, 1912, p. 518).

710-949-64-6 -5 
1900

NORTH NASHUA RIVER NEAR LEOMINSTER, MASS. (FEBRUARY AND MARCH)

"Monoosnock Brook and Nashua River are raging torrents which threaten to do serious damage. $* * *$ Monoosnock Brook is several feet above high water mark. William Hackett, who has been employed as an engineer at Rockwell's Mill for a long period of time, says that the Brook was never at such a high mark. All records have been broken in that respect" (Leominster Enterprise, Feb. 13, 1900).

" "Another dose of high water makes trouble. At the Rockwell property, the water was nearly as high as before" (Leominster Enterprise, Mar. 2, 1900).

ASHUELOT RIVER IN NEW HAMPSHIRE (FEBRUARY 13)

"Feb. 13, water ten and one-half inches higher than known since $1869 * * *$ * (Griffin, 1904, p. 704).

"Faulkner \& Colony reported higher water at their mill than known by them since the famous October freshet of 1869 . The water came in on the basement floor of the mill to a depth of two or three inches" (Keene Sentinel, Feb. 14, 1900).

WARE RIVER IN MASSACHUSETTS (DATE UNKNOWN)

"Owing to the heavy rains during the latter part of the winter of $1900 * * *$ [we] had the misfortune to lose three of our bridges ***" (Town Report, 1900, Ware, Mass.).

FARMINGTON RIVER IN CONNECTICUT (FEBRUART)

For relative flood elevations at Collinsville, refer to page 84 .

STILL AND MAD RIVERS NEAR WINSTED, CONN. (FEBRUARY AND MARCH)

"The river beat all records except the great flood of March four years since, and the water came within seven inches of that record breaker" (Waterbury American, Feb. 14, 1900).

"Winsted, Mar. 1. Today's rain developed another freshet surpassing that of a week ago, but attendant with less damage, however" (Meriden Record, Mar. 2, 1900).

BLACKBERRY RIVER IN CONNECTICUT (FEBRUART AND MARCH)

"Norfolk. 'The Island' was submerged for nearly two hours during which time the waters wrought havoc in some of the cellars" (Winsted Herald, Feb. 21, 1900).

"Norfolk. Yesterday's freshet was a record breaker, eclipsing all its predecessors for years back as far as the oldest inhabitants can remember. $* * *$ never known higher in the history of the stream" (Winsted Herald, Feb. 21, 1900).

SHEPAUG RIVER NEAR ROXBURT, CONN. (MARCH)

"The flood of Mar. 1 was the largest of the three that has visited us in the past few weeks" (Newtown Bee, Mar. 6, 1900). 
HOUSATONIC RIVER AT DERBY, CONN. (MARCH)

"One o'clock this morning, it reached the high water mark, 16 feet 10 inches, the highest flood since Jan. 8, 1874***.

"The measurements at the dam, which were marked on an automatic gauge showed that 6 feet 3 inches was the greatest. depth reached. The greatest depth of water ever reached on the: new dam was during the flood of Feb. 6, 1896, when 6 feet 4 inches were shown.

"Although the water in 1896 passing over the dam was one inch deeper than last night, yet the water below the dam did not rise so high, so that the present flood is the biggest Derby has had since 1874" (Derby Sentinel, Mar. 2, 1900).

NAUGATUCK RIVER IN CONNECTICUT (FEBRUARY)

"Thomaston. The water in the Naugatuck river here is higher than at any time for many years ***" (Waterbury Republican, Feb. 14, 1900).

1901

PENOBSCOT RIVER IN MAINE (APRIL 10)

"This flood was the greatest on record *** up to this time, with a maximum discharge at Bangor of 115,000 second-feet" (Grover, 1937, p. 440).

ANDROSCOGGIN RIVER AT RUMFORD, MAINE (APRIL 22)

For relative flood discharges, refer to page 76.

WEST BRANCH WESTFIELD RIVER IN MASSACHUSETTS (APRIL)

For comparative flood information, refer to oral communication by Mr. C. F. Pease, page 73.

WESTFIELD RIVER AT WESTFIELD, MASS. (APRIL)

"If the town ever had reason to appreciate the town dike it was on Sunday when the river at its height because of the Middlefield disaster. The water was not as high as in 1896 but it came with a rush and therefore more to be feared" (Times Newsletter, April 24, 1901).

RENNEBEC RIVER IN MAINE (DECEMBER 16)

"Continuous and systematic records of discharge of the Kennebec River at Waterville, Maine, were commenced by the Hollingsworth \& Whitney Co. in 1892. Since that time the discharge of the Kennebec River at Waterville has exceeded 100,000 secondfeet five times on the dates shown in the following list.

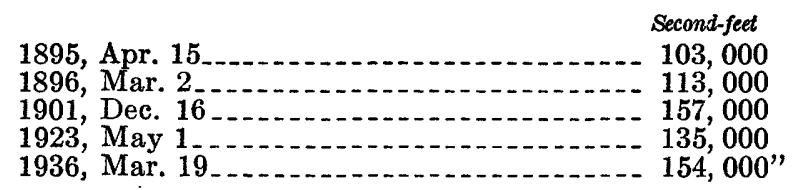

(Grover, 1937, p. 441). 
For relative flood stages at Winslow, refer to page 75, and for relative flood stages at Norridgewock refer to page 75 .

SANDY RIVER AT FARMINGTON FALLS, MAINE (DECEMBER)

For relative flood stages, refer to page 75 .

1905

PEQUONNOCK RIVER AT BRIDGEPORT, CONN. (JULY 29-30)

"On July 29-30, 11.32 inches of rain fell in 17 hours at Bridgeport, Conn. The resulting flood on the Pequonnock River [a Connecticut coastal stream], known as the 'Bridgeport flood', * * * Four mill dams failed, each failure increasing the magnitude of the flood, which fortunately discharged into Long Island Sound at ebb tide" (Hoyt and Langbein, 1955, p. 353).

RIVERS IN MAINE (SEPTEMBER)

1909

"*** the rain began last Wednesday when an unusual downpour for several days previous caused the Penobscot, St. Croix, Passadumkeag, and Pleasant Rivers to overflow their banks and rapidly rise to freshet pitch. The City of Calais bore the brunt of the trouble" (Bangor Daily, Oct. 1, 1909).

MACHIAS RIVER AT WHITNEYVILLE, MAINE (SEPTEMBER)

"An aged man in a neighboring town remarked that he never saw no such water in the river.

"The damage reported from up river is the going out of Canaan dam on Oldstream * * *" (Machias Union, Oct. 1, 1909).

1913

CONNECTICUT RIVER AT SOUTH NEWBURY, VT. (DATE UNKNOWN)

For comparative flood stages see oral communication by Judge Brock, page 70.

OTTAUQUECHEE RIVER IN VERMONT (MARCH 28)

A file in the Woodstock, Vt., library marked, "About Historic Floods of the Ottauquechee River, 1927," stated: "March 28, $1913 * * *$ Highest since '69 [1869]."

CONNECTICUT RIVER NEAR NORTH WALPOLE, N.H. (MARCH)

" * * * The highest peak of water in the river was at 6 o'clock Saturday morning when the gauge at the dam stood at 18.9. The last recorded high water before this was in 1895, when the same gauge indicated 19.4 at the peak" (Hayes, 1927).

"The water rose at a good rate and a little after 3 o'clock it was decided that the railroad tunnel should be blocked. $* * *$ the water did come up until it was about eight inches above the level of the track, at the mouth of the tunnnel" (Bellows Falls Times, Apr. 4, 1913).

CONNECTICUT RIVER IN MASSACHUSETTS AND CONNECTICUT (MARCH 29)

For relative flood stages, refer to page 85 . 
AROOSTOOK RIVER IN MAINE (MAY 2)

Mrs. H. H. Lamereau, age 66, who has always lived along the banks of the Aroostook, said that the flood of May 2, 1923, was definitely the highest that occurred between 1918 and 1942 . The water came to within 5 inches of the top of railroad fence posts along highway. There was no ice.

MEDUXNEKEAG RIVER NEAR HOULTON, MAINE (MAY)

“* * * All occupants of houses along the river front were obligated to move on Sunday, the water reaching over the first floor windows. Residents who have lived there for over 50 years, say that never has the water been so high" (Aroostook Pioneer, May 5, 1923).

ST. CROIX RIVER IN MAINE (MAY)

Mr. Windsor Deurah, superintendent of former Milltown, N.B., Cotton Mill, said that the mill was built in 1881-82. The flood of 1923 wrecked the old dam. Never since the mill was built in 1881 has there been higher water than that of May 1923 (oral communication, 1957).

MACHIAS RIVER IN MAINE (MAY)

"The storage dam at the foot of Machias First Lake had given away during the night ***. At the Machias bridge the water had reached a point higher than ever before reached" (Union Republican, May 3, 1923).

Mr. Stephen Tuell, age 57, Mr. Henry Durgan, age about 70, and Mrs. James Mattatill, age 87, all of East Machias, Maine, report that the flood of 1923 was the only flood that did any damage in East Machias during their lifetime (oral communications, 1957).

WEST BRANCH UNION RIVER AT AMHERST, MAINE (MAY 2)

"** * Worst disaster in Ellsworth history. Freshet of unprecedented height during Monday and Tuesday. The Wednesday afternoon break in new storage dam of the Bar Harbor and Union River Power Company at Brimmer's bridge" (Ellsworth American, May 2, 1923).

PISCATAqUIS RIVER AT MEDFORD, MAINE (MAY)

"Gage height of May 1, 1923 was 20.8 feet at site and datum then in use from highwater mark on Ferryman's house. Highest mark by local people" (from files of Geological Survey, Augusta, Maine).

PENOBSCOT RIVER IN MAINE (MAY 1)

"1923, May 1. This flood the largest of record in the Penobscot River Basin * * *" (Grover, 1937, p. 441). 
KENNEBEC RIVER IN MAINE (MAY 1)

- For relative flood stages at Norridgewock, refer to page 75, and for relative flood stages and relative flood discharges at.

Waterville, to pages 76, 63 .

SANDY RIVER AT FARMINGTON FALLS, MAINE (APRIL)

For relative flood stages, refer to page 75 .

ANDROSCOGGIN RIVER AT RUMFORD, MAINE (APRIL 22)

For relative flood discharges, refer to page 76 .

1924

WILLIMANTIC RIVER AT WILLIMANTIC, CONN. (APRIL 7)

"*** six dams along the Willimantic river overflowed five

feet, the highest record in 18 years" (Meriden Record, Apr. 8, 1924).

FARMINGTON RIVER IN CONNECTICUT (APRIL)

"At Unionville *** the highest mark in 25 years" (Torrington Register, Apr. 7, 1924).

For relative flood stages at Collinsville, refer to page 84 .

STILL RIVER NEAR WINSTED, CONN. (APRIL)

"Highland Lake, the largest body of water in the state, reached a new high water mark tonight when eleven and one half inches above high water was registered" (Waterbury Republican, Apr. 8, 1924).

PEQUABUCK RIVER NEAR BRISTOL, CONN. (APRIL)

"The south section of the city was flooded this morning. School street was completely under water" (Waterbury American, Apr. 7, 1924).

STILL RIVER IN DANBURY, CONN. (APRIL)

"*** streams have overflowed their curbs" (Waterbury American, Apr. 7, 1924).

POMPERAUG RIVER NEAR WOODBURY, CONN. (APRIL)

"The river badly flooded the flats making the river roads extremely dangerous to drive over" (Waterbury American, Apr. $8,1924)$.

NAUGATUCK RIVER IN CONNECTICUT (APRIL)

"The only conditions equalling that which prevailed today, according to old residents of the city [Torrington] was that which followed the flood of June 27, 1869" (Torrington Register, Apr. 7, 1924).

Naugatuck: "Mr. A. J. Campbell of C. L. \& P. Co., stated, 'The water in the Naugatuck river at the power plant in the West End was higher than at any previous time since they had started keeping records. The highest record the power company has is that of Jan. 22, 1910 when the water was 126.13 while this morning's depth read 127.92. The mean depth at this place is 118.'" 

"Ansonia. *** the Naugatuck river at its highest level
since 1914 ***" (Waterbury American, Apr. 7, 1924).

1927

"On November 3-4 a tropical storm *** swept northward across western New England. *** caused torrential rainfall and severe floods over extensive areas in virtually all of Northern New England and in the upper Hudson basin in New York. *** Extreme flooding was most severe in the White and Winooski valleys of Vermont" (Hoyt and Langbein, 1955, p. 372). ANDROSCOGGIN RIVER AT RUMFORD, MAINE (NOVEMBER)

For relative flood discharges, refer to page 76 .

PEMTGEWASSET RIVER NEAR WOODSTOCK, N.H. (NOVEMBER)

Mr. E. D. Westover, superintendent of the Beebee River Bobbin Plant of the Draper Corp., said that a Mr. Wallace, who was about 80 years old in 1924 when the Beebee River plant was built, had stated that the highest flood before 1924 was 16 to 18 inches over the railroad tracks at the office. On Nov. 4, 1927, the water reached a mark 5 feet 9 inches above the floor in the office of the Beebee River plant. The 1936 flood mark was just above the windowsills in the office, or 2 feet 6 inches above the floor. The floor is 3 feet 9 inches above the top of the rail, or 2 feet 3 inches above the highest flood that occurred before 1924. Thus, the 1927 flood was the highest flood known since about 1844 (oral communication, 1957).

Mr. F. Brown, the gage reader at the Woodstock gaging station, and his father, who is 90 years old, said that the 1927 flood was undoubtedly the largest flood that had occurred within their memory, or the memory of Mr. Brown's grandfather, which extends their knowledge back to about 100 years ago (oral communication, 1957).

baker river at warren, N.H. (NOVEMBER)

This flood was 3 feet 6 inches above the 1936 flood, according to marks in the basement of Henry Buskey's shop at the bridge on N.H. Highway 25.

At the state fish hatchery, just downstream from Warren, the November 1927 flood was the worst ever, according to Mr. R. S. Evans, the superintendent. He had a 1927 floodmark in the office of the fish hatchery 6 feet above the floor. The 1936, 1938, and 1942 floods were all roughly 1 foot deep in the office. The hatchery had been built in 1915 (oral communication, 1957).

PEMtgewasset RIVER AT PLYMOUTH, N.H. (NOVEMBER)

While making the historical flood investigation in the vicinity of Plymouth, N.H., it was established beyond any doubt that the 1927 flood was higher than that of 1936 on the Pemigewasset 
River above the effect of the Baker River, and on the Baker River above the effect of the Pemigewasset River. Nevertheless, there is clear evidence at Plymouth and for a short distance above the confluence of the two streams, that the 1936 flood was. higher than that of 1927. There is also evidence, from the comments of the people in the vicinity, that the peaks did not coincide.

MERRIMACK RIVER AT CONCOND, N.H. (NOVEMBER)

"The water at Concord is two feet higher than at any time in its history. Sewell's Falls Dam 12.2 feet. At the Bristol Dam the water was $10 \% \frac{1}{2}$ feet above the dam" (Concord Monitor, Nov. 5, 1927).

MERRIMACK RIVER AT MANCHESTER, N.H. (NOVEMBER)

For relative flood stages, refer to page 79.

MERRIMACK RIVER IN MASSACHUSETTS (NOVEMBER)

For relative flood heights over Pawtucket Dam at Lowell, Mass., refer to page 80 .

For relative flood stages at Lawrence, Mass., refer to page 81. QUINEBAUG RIVER IN CONNECTICUT (NOVEMBER)

"Quinebaug river highest since 1888. Three and one half feet over Dyer Dam" (Norwich Bulletin, Nov. 5, 1927).

"*** The Moosup River *** produced at the dam at Sterling, Conn., an estimate runoff of 3,000 second feet, or about 66 cfsm" (House Document 644, 71st Congress, 3rd Session, p. 13).

EAST BRANCH PASSUMPSIC RIVER IN VERMONT (NOVEMBER)

Mr. Gray, manager of the Lyndonville, Vt., Municipal Electric Co., said that the 1927 flood was the greatest to ever hit the town. Mrs. M. G. Humphry, said that she believed the 1927 flood was the highest since 1856 , when her family settled in the vicinity. Mr. Bowman, who runs the grain store in East Burke, Vt., said that the 1927 flood is the highest since at least 1902. Mr. Gaskell, 90-year old resident of East Burke, Vt., said that the 1927 flood was the only outstanding high water he could remember (oral communications, 1957).

MOOSE RIVER IN VERMONT (NOVEMBER)

In Concord, Vt., Mr. F. A. Lewis said (oral communication, 1957) that his ancestors were among the first settlers in Concord and that from his personal experience the only outstanding high water since at least 1881 was in 1927 . That was the only time the river ever got up into his barn.

In Victory, Vt., Mr. Stanley, whose family have lived for 117 years on the same farm on the banks of the Moose River, said (oral communication, 1957) that he knew of no outstanding high 
water, except maybe during November 1927. He believed that at that time the small streams flowing from the west into the Moose River caused more trouble than the river itself.

PASSUMPSIC RIVER IN VERMONT (NOVEMBER)

"The Main street at St. Johnsbury Center is about 15 feet under water. The water is 10 feet high on the walls of the Green Mountain Grange building.

"The record of 58 years had been broken by the flood according to oldest inhabitants. Mr. J. M. Rowe said that the worst previous flood was on October 2d 1869" (Caledonian Record, Nov. 4, 1927).

"Mr. P. J. Lachance, who has lived on the river bank on upper Railroad street in St. Johnsbury all his life, found by measurements taken at his wrecked home that this flood was four feet higher than that of 1869" (Walter, 1928, p. 13).

Mr. Skinner of Passumpsic, Vt., could remember the unusual high waters of 1896,1913, and 1936, and stated (oral communication, 1957) that they were not in the same class with the 1927 flood. He had heard stories of the October 1869 flood from his father-in-law. It did not compare with the 1927 flood, but he thought that it was greater than the flood of 1936.

AMMONOOSUC RIVER IN NEW HAMPSHIRE (NOVEMBER)

In Littleton, N.H., Mr. Holmes, powerplant superintendent of the Littleton Municipal Power Co., said that the 1927 flood was the greatest since at least 1875 when his family settled in Littleton (oral communication, 1957).

Mr. Straw, plant operator for the Bethlehem Power Co., Bethlehem, N.H., said (oral communication, 1957) that the 1927 flood was the highest since at least 1905, and that the 1936 flood was next highest. This flood was followed in magnitude by the flood of 1938.

In Lisbon, N.H., Mr. N. Fox, town clerk, believed that the 1927 flood was the greatest flood since the town was settled, in about 1780. He did not consider any other flood since 1900 outstanding. The only other outstanding flood that he had ever heard of was in 1869 (oral communication, 1957).

Mr. Robar of Lisbon, former power-station operator, said (oral communication, 1957) that the 1927 flood was $1 \frac{1}{2}$ feet higher at the dam than any other flood since at least 1909. Mr. C. N. Carriweton, of the same town, who can remember back to 1892, said (oral communication, 1957) that the 1927 flood was the highest ever known. He had heard of the 1869 flood. 
WELLS RIVER IN VERMONT (NOVEMBER)

Mr. Clark, who owns a store in Wells River, Vt., said (oral communication, 1957) that his family settled in Wells River in the early 1800's, and that the only time he had heard of the water flowing down Main Street was in November, 1927. He is certain that was the highest flood since at least 1900 .

Miss Tucker, postmistress of Boltonville, said (oral communication, 1957) that her father owned a grist mill which was washed away in the 1927 flood. She had heard stories of the 1869 flood from her father; however, it did not compare with the 1927 flood.

Mr. H. Brown of South Ryegate, Vt., said that he bought a farm along the Wells River when he was a young man. The farmer from whom he bought the place pointed out the highwater mark for the 1869 flood. Mr. Brown owned the farm during the 1927 flood, and the water was at least 2 feet over the 1869 flood mark at that time. He knew of no other outstanding floods since 1890 (oral communication, 1957).

CONNECTICUT RIVER NEAR NEWBURY, VT. (NOVEMBER)

Judge Brock, who lives in Newbury, Vt., said that his family settled in Newberry before the Revolution. His father put a spike in a tree on the banks of the Connecticut River to mark the high water of 1876 . In $1896, \mathrm{Mr}$ Brock put a spike in the saine tree 18 inches higher than the 1876 spike. He also put a spike in the tree in 1913 , but he cannot remember just where it fell in relation to the other two spikes. After the November 1927 flood Mr. Brock's son put a spike in the tree marking the high water. It was at least 2 feet higher than the highest spike in the tree (oral communication, 1957).

OMPOMPANOOSUC RIVER IN VERMONT (NOVEMBER)

Mr. H. E. Heaton of Post Mills, Vt., said that the 1927 flood was the highest since 1869. His family settled on their farm in 1819. His father told him of the 1869 flood, but from what little he had to go on, he felt that the 1927 flood was greater than the 1869 flood (oral communication, 1957).

WHITE RIVER IN VERMONT (NOVEMBER)

Mr. and Mrs. Spaulding who live in the town of Royalton, said that the 1927 flood was the greatest since at least 1896; and that the 1938, 1936, and 1913 floods follow in that order of magnitude. Their families have lived in Royalton for three generations, and they have never heard of any other floods (oral communications, 1957).

Mr. G. Ainsworth of South Royalton said that in 1867 his father acquired the farm which he now operates, and that soon after 1867 a great flood occurred which removed the pumpkins 
from the field. From landmarks described by his father, Mr. Ainsworth believes that this flood was higher than the 1938 flood, but not as high as the 1927 flood (oral communication, 1957).

"The White River valley suffered severely from the great November flood of 1927. Swollen by the tremendous downpour of rain, the main river and the Third Branch particularly passed all known flood stages. The First and Second Branches, while they reached very high levels, were not so destructive" (Johnson, L. B., 1928, p. 7).

\section{CONNECTICUT RIVER AT WHITE RIVER JUNCTION, VT. (NOVEMBER)}

Mr. E. Colby, who owns a farm on the banks of the Connecticut River, said that the 1927 flood was the highest since at least 1850 . If the water had come any higher it would have been over the first floor of his house, and if such a thing had happened previously, he would have heard of it from his father who settled there in 1850. Mr. Colby was 72 years old (oral communication 1957).

Mr. W. B. True, who owns a farm located along the Connecticut River in West Lebanon, N.H., stated that his family has lived on the farm since 1838 and the only time that the Connecticut River rose high enough to reach his cellar was in 1927. The next highest flood occurred in 1936, and he thought that it was about 3 feet lower than the 1927 highwater. The only other two high waters which he could recall as being outstanding since 1890 were those of 1896 and 1913, which were of about equal magnitude (oral communication, 1957).

OTTAUQUECHEE RIVER IN VERMONT (NOVEMBER)

Mr. Davis, who was manager of the Quechee Mills until his retirement in 1945, said that as far as he knows the 1927 flood was the greatest flood to hit the mills since they were built in the 1830 's. He cut notches in a door frame to show the heights of the 1927 and 1936 floods. The 1936 flood was 4 inches lower than the 1927 flood, but the 1936 flood was caused by ice jams. A Mr. Lindsey, who was the mill manager before Mr. Davis, told of a flood in 1869 which was the greatest until 1927. The 1869 flood destroyed one of the brick buildings of the mill (oral communication, 1957).

BLACK RIVER IN VERMONT (NOVEMBER)

Near Springfield, Vt., Mr. M. White, retired official of Vermont Foundry, pointed out some bronze flood markers that were placed around the foundry after the Nov. 4, 1927, flood on the Black River. Mr. White also said that the 1936 and 1938 floods were 
at least 5 feet lower than the 1927 flood at the foundry (oral communication 1957).

Mr. Balch, assistant general foreman of maintenance of Fellows Gear Shaper Co., said that the 1927 flood was the highest since 1893, and that the 1936 and 1938 floods were about equal in height at the plant. They have high-water markers for the 1927 flood scattered throughout the buildings (oral communication, 1957).

WILLIAMS RIVER IN VERMONT (NOVEMBER)

For comparative flood heights at Chester, Vt., refer to oral communications by Mrs. Davis, Mr. Hawkes, and Mr. Crocker, page 87.

Mr. Ellison said that the 1927 flood was higher in the town of Bartonsville than the flood of 1938. He had heard of no other floods of any outstanding magnitude (oral communication, 1957).

In Brockway Mills, Vt., Mrs Parkhearst, owner of the farm by the gaging station, could remember back to at least 1900 . Her father had owned the mill just downstream from the bridge. Mrs. Parkhearst said that the 1927 flood was the highest flood in that vicinity since at least 1869 . She believed that the water was almost 2 feet higher than in 1938, because it was over the abutments of the bridge in 1927, but wasn't in 1938 . She was quite sure that this great height in 1927 was caused by the mill dam which was just downstream from the bridge. She said that the dam went out during the 1927 flood and caused a rapid recession in the stage in the vicinity of the gauge. She was quite certain that the discharge was greater during the 1938 flood, even though the stage was not as high. She also remembered hearing her father tell of a flood in 1869 which she believed was not as great as the 1927 flood. The mill dam was there during the 1869 flood (oral communication, 1957).

SAXTONS RIVER IN VERMONT (NOVEMBER)

For comparative flood information, see oral comnunication by Mr. A. H. Thompson, page 42 .

CONNECTICUT RIVER NEAR NORTH WALPOLE, N.H. (NOVEMBER)

"Bellows Falls and Vicinity *** The water level rose above all previous marks, reaching a height of 25 feet and 8 inches above the level of the old dam.

“*** All available help was put at work to prevent the water from the canal passing through the railroad tunnel under the main part of the business section of the village. $* * *$ The effort was successful and little water passed through. When the peak of high water was reached ${ }^{*} *$ it stood at 7.46 feet 
above the rails. During the last year the rails in the tunnel have been lowered 18 inches, so in comparison with former years that amount should be deducted" (Hayes, 1927).

WEST RIVER IN VERMONT (NOVEMBER)

For comparative flood information, see oral communication by Mr. Charles Taft, page 42 .

CONNECTYCUT RIVER AT VERNON, VT. (NOVEMBER)

"At 2 o'clock this afternoon the water stood 14.9 feet deep on the crest of the Vernon Power Plant Dam [built in 1907].

"The highest previous mark was 12/1/2 feet in 1913" (Brattleboro Reformer, Nov. 4, 1927).

WEST BRANCH OF WESTFIELD RIVER IN MASSACHUSETTS (NOVEMBER)

Mr. C. F. Pease, owner of the dry goods store on the bank of the river by one of the bridges in Chester, Mass., said that the 1927 flood was highest owing to the dam break in Becket and that the 1901 flood was next. This flood was caused by a dam break in Middlefield, Mass. The floods of 1938 and 1955 were next in height after the 1901 flood, in that order (oral communication, 1957).

Mr. Donnelly of the Hamilton Emery and Carborundum Co., pointed out flood marks in the basement of one of their buildings. The mark for the flood of 1927 was about 12 inches higher than that for the 1938 flood, which was about 12 inches higher than that for the 1955 flood.

WESTFIELD RIVER AT WEST SPRINGFIELD, MASS. (NOVEMBER)

For comparative flood discharges, refer to page 50.

CONNECTICUT RIVER IN MASSACHUSETTS AND CONNECTICUT (NOVEMBER)

For relative flood stages, refer to page 85 .

BTILL RIVER IN CONNECTICUT (NOVEMBER)

"Winsted. Highland lake reached the highest level ever recorded here in last night's storm. The waters of the lake were a foot above any mark they had ever previously reached. The nearest to the flood level of last night was reached more than 25 years ago" (Waterbury American, Nov. 4, 1927).

FARMINGTON RIVER IN CONNECTICUT (NOVEMBER)

For relative flood stages at Collinsville, refer to page 84 .

EAST BRANCH HOUSATONIC RIVER IN MASSACHUSETTS (NOVEMBER)

"Worst flood in the history of North Berkshire. Not in memory of oldest inhabitants of the city has such a catastrophe visited the city" (Berkshire Eagle, Nov. 4, 1927).

HOUSATONIC RIVER IN MASSACHUSETTS (NOVEMBER)

"Saturday morning a high-water mark was reached that has never before been recorded. The flood waters reached the highest 
point on the $4 \mathrm{~A}$. S. fairgrounds, in the memory of the oldest inhabitants at this point, the inside fence on the racetrack at the southwest corner was covered with water, a depth of over five feet. The cattle barns were flooded to a depth of five feet" (Berkshire Courier, Nov. 10, 1927).

BLACKBERRY RIVER IN CONNECTICUT (NOVEMBER)

"Litchfield county was swept by the worst flood in its history last night" (Hartford Courant, Nov. 4, 1927).

NAUGATUCK RIVER IN CONNECTICUT (NOVEMBER)

"The central streets of Torrington were inundated by the Naugatuck River" (Hartford Courant, Nov. 4, 1927).

"Thomaston. Flood waters have reached an unheard of level ***" (Winsted Citizen, Nov. 4, 1927).

"Waterbury: The maximum height of the flood recorded by the transit men from the city engineer's office, was a foot higher than the flood of three years ago" (Waterbury American, Nov. 5, 1927).

"Seymour. The water of the Naugatuck River was the highest ever seen $* * *$ without the aid of ice" (Naugatuck Sentinel, Nov. 4, 1927).

HOUSATONIC RIVER AT DERBY, CONN. (NOVEMBER)

For relative flood stages, refer to page 85 .

1928

CONNECTICUT RIVER NEAR DALTON, N.H. (APRIL)

"Guildhall, Vt. The Connecticut River rose to the highest point ever known ***" (Coos County Democrat, Apr. 11 . 1928).

Mr. Mansfield, chief electrician at the Gilman Paper Co., said that the 1928 flood was the highest since at least 1912. He did not think that the 1936 flood was as bad as that of 1928 , but that was probably due to the fact that a good part of their dam was taken out by the ice during the 1928 flood (oral communication, 1957).

For comparative flood information see oral communication by Mr. Bell, page 82 .

ST. JOHN RIVER IN MAINE (MAY 5)

1933

$\mathrm{Mr}$. Irenee $\mathrm{Cy}$, age 83 years, who moved to Fort Kent, Maine, in 1896, said that the highest water he could remember was that in 1933, when water was just up to new concrete road in front of Daigle's Hardware Store. He spoke of a picture taken during 
this flood in front of the old hotel where men were waist high in water (oral communication, 1957).

Several other people in Fort Kent recalled only one real flood, that of 1933.

1936

"**** From March 9 through 22 there occurred in close succession over the northeastern United States $* * *$ two extraordinarily heavy rainstorms. $* * *$ At the time of the rain there were accumulations of snow on the ground over much of the area $* * *$. The floods resulting from this combination of events were unusually devasting. Records of river stages extending on some of the streams back or nearly back to the time of settlement by white men were broken, many of them by a wide margin" (Hoyt and Langbein, 1955 , p. 382, 383).

SANDY RIVER AT FARMINGTON FALLS, MAINE (MARCH 19)

"A study of relative flood elevations of Sandy River at Farmington Falls as determined in 1936 by C. H. Hardison of the Geological Survey at site indicates that the March 19, 1936, flood was the greatest since 1776 when the area was settled:

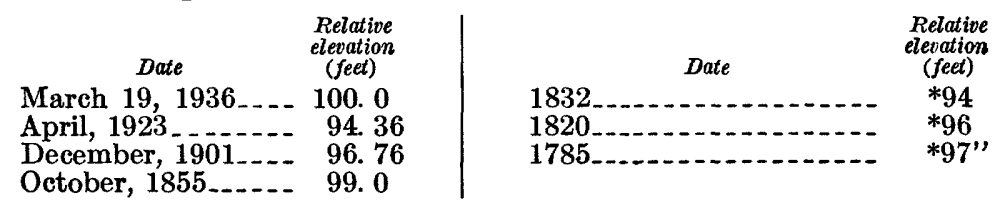

* Elevations estimated from data supplied Mr. Hardison by A. A. Gordon, mill owner and historical material owned by Mrs. Morrow.

(from files of Geological Survey at Augusta, Maine).

KENNEBEC RIVER IN MAINE (MARCH 19)

"The altitudes, in feet above mean sea level, reached during various floods on the Kennebec River at the gristmill at Norridgewock, Maine, as determined from marks on a foundation post under the mill, are given below:

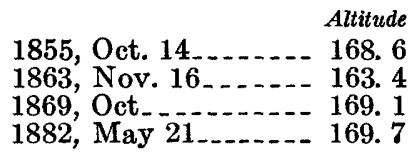

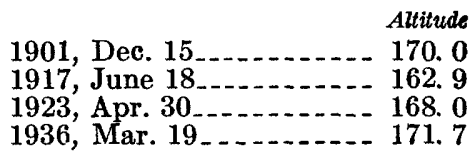

"These stages were affected by the dam at Skowhegan. When the new dam was built, in 1920, the ledge was blasted out, and two 30-foot Taintor gates were installed with their sills 2 feet lower than the sills in the old dam. When these gates are opened the new dam has more discharge capacity than the old one" (Grover, 1937, p. 441).

For relative flood discharges at Waterville, refer to page 63 . 
"The approximate altitudes reached during previous floods on The Kennebec River at the 'freshet oak' in Winslow and at the Lockwood power house in Waterville:

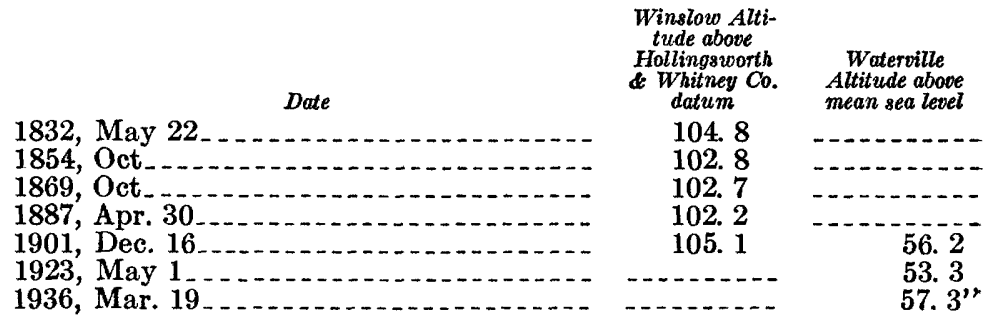

(Grover, 1937, p. 442).

"The altitudes, in feet above mean sea level, reached during previous floods on the Kennebec River at Hallowell, as determined from marks on the corner of the building at 136 Water Street:

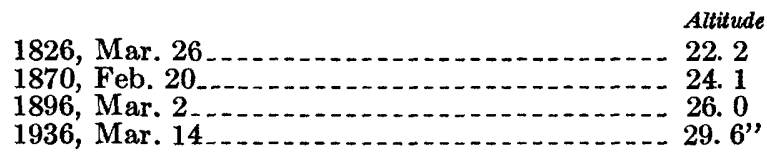

(Grover, 1937, p. 442).

ANDROSCOGGIN RIVER IN MAINE (MARCH)

"In ***1936 the peak flow of the Androscoggin River from Rumford, Maine, downstream exceeded all past records. the maximum flows for the major floods on the Androscoggin River at Rumford since the beginning of systematic records in 1892:

Date
1893, May 18
1895, Apr. 15, Mar. 2
1901, Apr. 22,
1917, June 18
1923, Apr. 30. 1927 , Nov. 5
1936, Mar. 19

\begin{tabular}{|c|c|}
\hline $\begin{array}{c}\text { Average } \\
\text { discharge for } \\
\text { maximum day }\end{array}$ & Peak discharge \\
\hline 38,100 & - \\
\hline 55,200 & - \\
\hline 39,000 & - \\
\hline 32,700 & ג \\
\hline 30,300 & - \\
\hline 33,800 & - \\
\hline 39,100 & $\begin{array}{l}46,700 \\
74,\end{array}$ \\
\hline b8, 500 & 74,000 \\
\hline
\end{tabular}

(Grover, 1937, p. 444).

For comparative flood stages, see page 11.

SACO RIVER IN Maine (MarCh)

For comparative flood stages at Fryeburg,Maine, see page 19.

"According to information obtained from old residents and from such records as are available, the flood of March 19-22, 1936, was the greatest flood ever known in the lower Saco River in Maine, both in stage of the river and in volume of flow. The following list shows altitudes, in feet above mean sea level, of 
highwater marks of floods on the Saco River as kept in Sand's blacksmith shop in West Buxton, Maine:

\begin{tabular}{|c|c|}
\hline 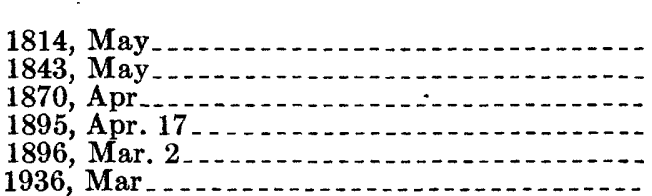 & $\begin{array}{r}* 165.3 \\
162.8 \\
162.8 \\
162.8 \\
166.2 \\
168.2\end{array}$ \\
\hline
\end{tabular}

*From note stating that the 1814 flood was 2.5 feet higher than the flood of 1813 (from files of Geological Survey at Augusta, Maine).

(Grover, 1937, p. 447).

PEMIGEWASSET RIVER AT WOODSTOCK, N.H. (MARCH)

For comparative flood heights, see oral communication by Mr. E. D. Westover, page 67.

BAKGR RIVBR AT WARREN, N.H. (MARCH)

For comparative flood heights, see oral communication by Mr. R. S. Evans, page 67.

PEMIGEWASTET RIVER AT PLYMOUTH, N.H. (MARCH)

The home of Mr. George Clark in Plymouth, which is said to be 175 years old, had water get into its basement only one time during the entire period; that was during the great flood of 1936 (oral communication, 1957).

SMITH RIVER NEAR BRISTOL, N.H. (DATE UNKNOWN)

Mr. Carl Gordon who lives about 2 miles above the Smith River gaging station has been observing the river since 1885 . He said that without a doubt, the 1936 flood was the highest that has occurred since he was able to pay attention in 1885 (oral communication, 1957).

CONTOOCOOK RIVER AT CONTOOCOOK, N.H. (MARCH)

In Contoocook, N.H., Mr. Arthur Huntoon, who was born in 1888 and was town clerk for many years, said that the 1936 and 1938 floods were the largest known. Mr. Huntoon's mother was the postmistress in the 1860's, and he remembers her saying that the floods of 1895 and 1896 did get into Water Street but not into the square. Mr. Huntoon said that the floods of 1936 and 1938 got to about the level of the soda fountain in the drugstore in town (oral communication, 1957).

The fact that the 1936 and 1938 floods were about the same was confirmed by a number of people in Contoocook in 1957.

WARNER RIVER IN NEW HAMPSHIRE (MARCH)

Mr. N. H. Reuben Moore of Bradford, N.H., who has lived in Bradford for 63 years and has made a serious study of the history of Bradford, said that no floods were known prior to 1936 for at least two generations (oral communication, 1957).

Mr. G. W. Rogers at Melvin's Mills, several miles below Bradford, who had lived at the mills for 88 years, said that the 710-949-64-6 
mills were built long before 1869 and that his father bought the mill in 1845 . He knew of no damage to the mill from freshets until 1936 when the waterwheels and much of the other machinery were carried away. He believed that the 1936 flood was the highest that ever occurred during the history of the mill. $\mathrm{He}$ did not know whether the 1938 flood was as high as the 1936 flood (oral communication, 1957).

Mr. Davis, whose family settled in Davisville in about 1812 or 1818 and had the town named after them, knew of no flood like those of 1936 and 1938 (oral communication, 1957).

BLACKWATER RIVER IN NEW HAMPSHIRE (MARCH)

Mr. E. C. Gerrish, 90 years old, who worked in the office of the Proprietors of the Locks and Canal on the Merrimack River at Lowell, recalled no other flood as big as that of March 1936. He did not recall any serious high water on either the Blackwater or the Contoocook River in 1895 or 1896, though he was in Lowell at the time and does recall the very serious flood in Lowell in 1896. He remembered distinctly a nail set in a pine tree by his grandfather at the height of an August freshet that occurred many years ago. This is very probably the 1826 flood, which has been referred to several times as an outstanding flood in the valley of the Contoocook, and which occurred in August. The tree in which the nail was driven had long since disappeared, but he is of the opinion that, in the immediate vicinity, the 1936 flood was at least 5 feet higher than the nail in the tree, as he remembered it (oral communication, 1957).

CONTOOCOOK RIVER NEAR PENACOOK, N.H. (MARCH)

Mr. Ralph Sherburn, who was postmaster in Penacook and whose father was postmaster before him, knew of all outstanding floods that had occurred since 1885. He said that the 1936 flood was at least 10 feet higher than that of 1896 . The $1936 \mathrm{flood}$ was up to the bridge in Penacook but the 1896 flood was just barely up to a wall which is a considerable distance under the bridge (oral communication, 1957).

Mr. R. E. Boutwell, living at Tyler's Bridge on the right bank, knew of a house belonging to Admiral Burrege, about one-half mile below Tyler's Bridge, in which there were two flood marks about 3 or 4 inches apart, one of the 1895 and one of the 1896 flood, but he did not remember which was the higher. The flood of 1936 was about 5 feet higher than those flood marks, or 18 inches deep on the floor of the barn. The house belonging to Admiral Burrege was about 100 years old (oral communication, 1957). 
SUNCOOK RIVER IN NEW HAMPSHIRE (MARCH)

Mr. Harry Silver of Epsom, N.H., who was born in 1882 and has lived in the vicinity all of his life, remembered the flood of 1896 which ripped out some bridges and railroad embankment and delayed the trains for several days. He also remembered the 1936 flood and believed that the 1896 flood may have been nearly as big as that of 1936 (oral communication, 1957).

Mrs. M. B. Emerson of Pittsfield, N.H., had a diary that her father, L. D. Muchmore, kept from 1872 to 1939. In 1936, Mr. Muchmore made the following entries: March 18, "A flood. White's Dam gone. Water over Barnsted Road." March 19, "No trains. Soucook Bridge gone in Chichester. Hartwell Dam and part of mill gone. Worst flood in New Hampshire ever known."

MERRIMACK RIVER AT MANCHESTER, N.H. (MARCH)

"The following record of flood heights, in feet, of the Merrimack River has been obtained from flood marks in one of the mills of the Amoskeag Co. at Manchester, N.H.:

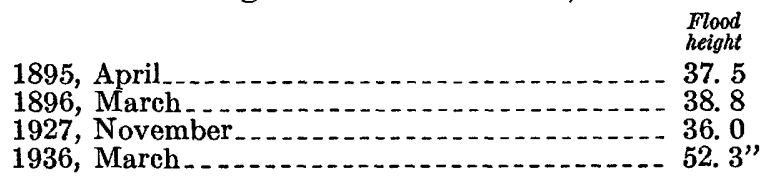

(Grover, 1937, p. 449).

According to records kept at the Amoskeag Co. mill, the highest floods since 1785 are:

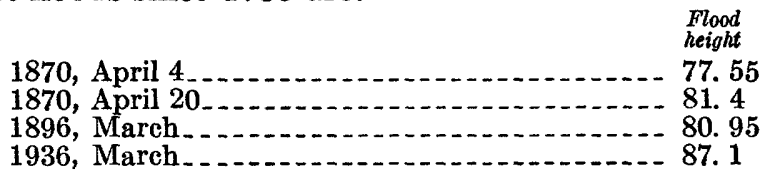

(Browne, 1915, p. 184, 185).

SOUTH BRANCH PISCATAQUOG RIVER IN NEW HAMPSHIRE (MARCH)

Mrs. Saltmarsh, whose husband used to work for the owner of the small dam and mill in New Boston, said that the 1936 flood was higher than that of 1938 (oral communication 1957).

All the persons queried in New Boston stated that the 1936 flood was higher than that of 1938 and that no other flood has been known to get in the Common as did those two.

SOUHEGAN RIVER IN NEW HAMPSHIRE (MARCH)

"On October 3 and 4, 1869, 71/4 inches of rain fell. The Souhegan was the highest ever known. The water was a foot deep in Wilton Road at the Tucker place, and filled the arch of the stone bridge to within $1 \frac{1}{2}$ feet of the top of the arch. The bridge had been built in 1846" (Ramsdell, 1902). 
Mrs. Haywarst who, during the 1936 flood, lived in a house on what used to be the Tucker place said that during the 1936 flood they had a boat handy to take them out if the river rose any higher than the first floor. Only trucks were able to get through on the highway (the Wilton Road referred to by Ramsdell), so evidently the water was somewhat higher at that place than it was in 1869 (oral communication, 1957).

At Milford, N.H., Mr. Goldwin, who owns a mill just downstream from the arch bridge referred to by Ramsdell, said that the bridge was rebuilt in 1931, the arches being left almost as they had been. In the 1936 flood the arches were full. A crib dam a short distance below the bridge was said to be in good condition in 1936 and presumably also in good condition in 1869. In 1957 it was in ruins. Mr. Goldwin also stated that in 1938 the arch lacked about 6 feet of being full and that the 1927 flood was only what he called "high water" (oral communication, 1957).

NORTH NASHUA RIVER IN MASSACHUSETTS (MARCH)

Mr. C. E. Pethybridge, the assistant city engineer of Fitchburg, said that the 1936 flood was the biggest flood of record and that the flood of 1900 was not so bad (oral communication, 1957). Mr. Pethybridge wrote an excellent report on the 1936 flood in the Annual Report of the Department of Public Works of the city of Fitchburg. His statements include many landmark data, such as depths of water over streets and head on dams and rather complete detail about the damages, but he made no reference to any prior floods. His 1936 report stated that it was the highest flood ever recorded in Fitchburg.

Mr. F. Wyman at the Falulah Paper Co., the lowest of the mills in Fitchburg, said that the 1936 flood was the worst in 40 years (oral communication, 1957).

MERRIMACK RIVER AT LOWELL, MASS. (MARCH 20)

"Records of stages of the Merrimack River at Lowell, Mass., kept by the water-power companies since 1846 show that the city of Lowell has experienced a considerable number of large floods, the six largest floods of record $* * *$. The following table shows heads on the Pawtucket Dam ***.

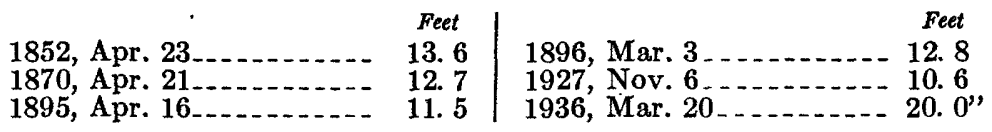

(Grover, 1937, p. 450).

MERRIMACK RIVER AT LAWRENCE, MASS. (MARCH 20)

"The Essex Co. has kept records of stage above the dams at Lawrence, Mass. since 1846. The following table shows the date, 
gage height, in feet, and head on the dam, in feet, for the major floods since that date:

\begin{tabular}{|c|c|}
\hline 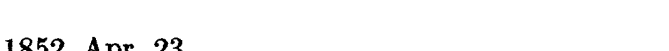 & Gage height \\
\hline 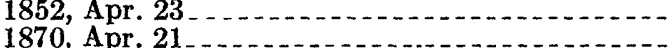 & $\begin{array}{l}\text { 44. } 12 \\
43.48\end{array}$ \\
\hline 1896, Mar. 3 & 43.90 \\
\hline 1927, Nov. & 43. 46 \\
\hline - & 43. 00 \\
\hline & 48. 00 \\
\hline
\end{tabular}

"In using these records for comparisons it should be kept in mind that the crest of the dam may not always be swept entirely clear of flashboards during the major floods" (Grover, 1937, p. 451 ).

PARKER RIVER IN MASSACHUSETTS (MARCH)

Mr. Pearson, owner of the Byfield Snuff Mills, which has been in his family since the 1700 's, reports that the 1936 high water was the highest since at least 1900 . Mr. Brown who has lived in Byfield since 1900 verifies Mr. Pearson's statement (oral communication, 1957).

IPSWICH RIVER IN MASSACHUSETTS (MARCH)

Mrs. Haywood, who owned the land on which the gage house was located in South Middleton, said that the 1936 flood was the highest in the 50 years that she had lived there (oral communication, 1957).

"Many of the citizens of the town say that 50 years ago the Ipswich River was much higher than it has been during the past week, but the majority of the townspeople have never seen so much rushing water as there has been down the river the past several days" (Ipswich Chronicle, March 20, 1936).

For a statement of relative flood heights, see oral communication by Mr. Bowen, page 52 .

BLACKSTONE RIVER IN MASSACHUSETTS (MARCH)

"March 13, 1936. The gage shows that the flood of yesterday established a new high water record for the Blackstone River, with the mark showing at 4 inches higher than at any time since 1867. At that time, 59 years ago, the record mark was 60 inches above normal (from a scrapbook of newspaper clippings in the Uxbridge, Mass., library).

WILLIMANTIC RIVER AT STAFFORD SPRINGS, CONN. (MARCH 12)

"Worst flood on Willimantic River since March 1877" (Hartford Courant, Mar. 14, 1936).

NATCHAUG RIVER IN CONNECTICUT (MARCH 12)

"In the worst freshet that has visited this locality in the last forty years" (Willimantic Chronicle, Mar. 12, 1936). 
QUINEBAUG RIVER IN CONNECTICUT (MARCH)

"Quinebaug beat 1886 high at Putnam" (Norwich Bulletin, Mar. 13, 1936).

"Putnam. Worst flood in history. For an all time record within the memory of living man, nine feet of water was pouring over the Dyer Dam at one o'clock this afternoon" (Norwich Bulletin, Mar. 20, 1936).

"Aspinook Dam was under far greater pressure in its history since 1894. Quinebaug poured 8 feet over the 600-foot spillway. At Jewett City the flood reached nearly the same height as in 1886" (Norwich Bulletin, Mar. 21, 1936).

CONNECTICUT RIVER ABOVE DALTON, N.H. (MARCH)

"Lancaster had its highest water in its history.

“E. M. Monahan's farm at South Lancaster was another flood victim. Here the water passed all previous records. The farm was formerly owned by the late Jacob Benton who had placed on the barn a mark to indicate what point water reached in the flood of 1870 [possibly 1876]. During the flood of 1927 the water came within six inches of the 1870 level, and last Thursday it was two feet higher" (Coos County Democrat, Mar. 25, 1936).

Mr. Bell, who owns a store on the banks of the Connecticut. River in the town of Gilman, said that his family has owned a farm along the Connecticut River since at least 1800. Based on landmarks pointed out to him by his father and grandfather, Mr. Bell believed that the 1936 flood was the greatest ever and that the 1928 flood was the next highest (oral communication, 1957).

MASCOMA RIVER IN NEW HAMPSHIRE (MARCH 19)

Mr. S. H. Stevens, the town civil engineer in Lebanon for many years, stated in "Highways, No. 15," a surveyor's field notebook now in the Lebanon, N.H., town hall: "Water surface at Emerson's Gardens, No. 23 Spencer Street, 578.30 feet above mean sea level. Highest ever known in Lebanon.

"Crest of dam 568.29 showing height of water flowing over dam to be 5.5 feet. Estimated volume 6,000 second feet.

"In the first Lebanon Directory (1882) mention is made of the 'Great Flood of 1869 when the water stood 4.5 feet above the crests of the dams.' The crest of the Everett Norfolk Dam has never changed."

Mr. Stevens said that, on the basis of his own personal experience, the 1936 flood was the greatest since at least 1890 and, on the basis of his reading of histories and old records, also the greatest since the vicinity was settled, about 1750 (oral communication, 1957). 
SUGAR RIVER IN NEW HAMPSHIRE (MARCH)

Mr. LaCross, patrolman in Newport, said that he had lived through four floods. He graded the floods in the order of their magnitude: the 1936 flood being the highest, followed by the 1938 flood, the 1934 flood, and then by the 1927 flood. He had heard of no other floods affecting the town; he can remember back to 1900 (oral communication, 1957).

Mr. G. L. Edes, real estate agent in Newport, said that he could remember the 1936 flood as the highest since about 1900 . He also remembered the 1938, 1934, and 1927 floods in that order as to their relative magnitude (oral communication, 1957).

Mr. Bosworth, plant engineer of Claremont Paper Mills, pointed out some high-water marks in the wheelhouse of their power plant. They had a mark labeled " $3-18-36$ "; 35 inches below that they had a mark for the " $9-21-38$ " flood; and 20 inches below the 1938 mark, they had a mark for the Nov. 4, 1927, flood.

ASHUELOT RIVER IN NEW HAMPSHIRE (MARCH)

Mr. J. Faulkner, who lived in Swanzey, was the last owner of the Faulkner and Colony Mills in Keene. At one time he wrote a report on the relative heights of the various floods at the Faulkner and Colony Mills. He said that the 1936 flood was the highest (possibly due to an ice jam) and that the 1938 flood was only a little lower than that of 1936 . He thought the 1869 flood was third in the order of descending magnitude, followed by the 1900 and 1927 floods, which were just about equal. The relative magnitude of the floods is based on the depth of water on West Street outside the mills and depth of the water in the basement of the mills (oral communication, 1957).

Flood marks, chiseled into the granite foundation of the Federated Church on the corner of Main and Parker Streets in Winchester, N.H., were located on the back corner of the Parker Street side of the church. The 1936 flood was clearly marked about $4 \frac{1}{2}$ feet above ground level. A mark, about 14 inches below the 1936 floodmark and dated 1869, was not as clear because it was weathered. Another mark about 18 inches below the 1869 mark was quite difficult to make out but it appeared to be "1859."

Reports of local residents indicate that these marks represent all the floods since 1859 except for the flood of 1938. All seemed to agree that the 1938 flood was either higher or equal to the 1936 flood.

Mr. L. Gratton, president of G. E. Roberson and Co., said that he could not remember anything in 1920 that compared with the high water of 1938 . "Of course," he said, "the outstanding high water was that of 1936" (oral communication, 1957). 
MILLERS RIVER IN MASSACHUSETTS (MARCH)

Mr. Deering, who worked in the office of the New England Wooden Ware Corp., located along the Millers River in the vicinity of Winchendon, Mass., said that during the flood of 1936 he talked with a lifelong resident, who was 80 years of age at that time, who mentioned that the 1936 flood was the highest flood he had ever witnessed (oral communication, 1957).

Mr. Sullivan of Bondsville, Mass., who operates a clothing store next to the post office, could remember back 80 years (to 1877), and he could not recall any flood as bad as the 1936 flood. In fact the only other flood of any magnitude that he could recall was the 1938 flood (oral communication, 1957).

NORTH RIVER IN MASSACHUSETTS (MARCH)

For comparative flood heights, see oral communications by Mr. Nickles and Mr. Call, page 89.

FARMINGTON RIVER IN CONNECTICUT (MARCH)

\begin{tabular}{|c|c|c|c|}
\hline \multirow[b]{2}{*}{ Date } & \multirow{2}{*}{$\begin{array}{c}\text { New Boston, } \\
\text { Mass. } \\
\text { (discharge, in } \\
\text { second-feet) } \\
\text { per square } \\
\text { mile) }\end{array}$} & \multicolumn{2}{|c|}{ Collinsville, Conn. } \\
\hline & & $\begin{array}{l}\text { Upper dam } \\
\text { (depth over } \\
\text { dam in feet) }\end{array}$ & $\begin{array}{l}\text { Boiler house } \\
\text { (altitude, in } \\
\text { feet, above } \\
\text { mean sea } \\
\text { level) }\end{array}$ \\
\hline $\begin{array}{l}\text { 1869, October } \\
\text { 1878, December } \\
\text { 1896, March } \\
\text { 1900, February } \\
\text { 1913, October. Mareh } \\
\text { 1921, } \\
\text { 1924, April } \\
\text { 1927, November } \\
\text { 1936, Movember }\end{array}$ & \begin{tabular}{r|}
34.8 \\
27.4 \\
37.5 \\
85.9 \\
39.2 \\
98.7
\end{tabular} & \begin{tabular}{|c|}
10 \\
\\
\\
\\
\\
$\mathbf{7 . 4}$ \\
$\mathbf{9 . 0}$ \\
$\mathbf{5 . 2}$ \\
$\mathbf{9 . 0}$
\end{tabular} & $\begin{array}{r}283.80 \\
283.21 \\
282.36 \\
282.07 \\
283.01 \\
282.91\end{array}$ \\
\hline
\end{tabular}

"The records at New Boston, Mass., were obtained at the river-measurement station of the Geological Survey. The dra inage area at that place is 92.0 square miles.

"The upper dam at Collinsville, Conn., is reported to have remained practically unchanged from prior to 1869 until 1935 , when the length of the spillway was increased from 329.6 feet to 342.5 feet. There were no flashboards on the dam during any of the floods recorded.

"The altitudes in the fourth column were determined $* * *$ from the high-water marks and dates or the floods as engraved on a plank on an interior wall of the Collins Company's boiler house, about a quarter of a mile downstream from the upper dam at Collinsville. It is stated that during the floods of December 1878, March 1896, and February 1900 the stage may have been affected by ice jams" (Grover, 1937, p. 457). 
CONNECTICUT RIVER IN MASSACHUSETTS AND CONNECTICUT (MARCH)

\begin{tabular}{|c|c|c|c|c|c|c|}
\hline \multirow{2}{*}{ Year ${ }^{1}$} & \multicolumn{2}{|c|}{ Holyoke, Mass. } & \multicolumn{2}{|c|}{ Springfieid, Mass. } & \multicolumn{2}{|c|}{ Hartford, Conn. } \\
\hline & Date & $\begin{array}{l}\text { Stage } \\
\text { (foet) }\end{array}$ & Date & $\begin{array}{l}\text { Stage } \\
\text { (feet) }\end{array}$ & Date & $\begin{array}{l}\text { Stage } \\
\text { (feet) }\end{array}$ \\
\hline $\begin{array}{l}1683 \\
1692 \\
1801 \\
1841 \\
1843 \\
1854 \\
18692 \\
1869 \\
1869 \\
1901 \\
1913 \\
1927 \\
19336 \\
1938 \\
1955\end{array}$ & $\begin{array}{l}\text { May } 1 \\
\text { Apr. } 20 \\
\text { Apr. } 22 \\
\text { Oct. } 5 \\
\text { Apr. } 8 \\
\text { Mar. } 29 \\
\text { Nov. } 5 \\
\text { Apr. 20 } \\
\text { Mar. 19-20 } \\
\text { Sept. } 22 \\
\end{array}$ & $\begin{array}{r}10.5 \\
12.5 \\
11.2 \\
12.7 \\
11.4 \\
12.0 \\
14.8 \\
12.4 \\
16.8 \\
14.9\end{array}$ & $\begin{array}{l}\text { Mar. } 20 \\
\text { May. } 120 \\
\text { Apr. } 20 \\
\text { Apr. 21 } \\
\text { Oct. } 4 \\
\text { Apr. } 9 \\
\text { Mar. } 29 \\
\text { Nov. } 6 \\
\text { Apr. } 20 \\
\text { Mar. } 20 \\
\text { Sept. } 22 \\
\end{array}$ & \begin{tabular}{r}
-21.7 \\
\hdashline 22.3 \\
20.5 \\
22.2 \\
21.0 \\
21.5 \\
19.8 \\
20.2 \\
22.4 \\
19.9 \\
28.6 \\
25.8 \\
\end{tabular} & 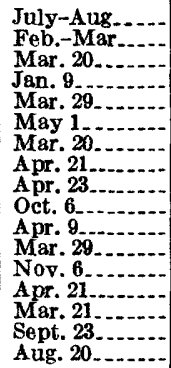 & $\begin{array}{l}26.0 \\
26.2 \\
27.5 \\
26.3 \\
27.2 \\
29.8 \\
26.4 \\
28.7 \\
26.7 \\
26.3 \\
26.4 \\
26.3 \\
29.0 \\
26.0 \\
37.6 \\
35.4 \\
30.6\end{array}$ \\
\hline
\end{tabular}

1 Data for 1683-1936, Grover (1937, p. 453-455); 1938, Bernard (1941, p. 24, 25); 1955, Reichelderfer (1955, p. 27).

QUINNIPIAC RIVER IN CONNECTICUT (MARCH)

"Hanover Lake-Albert Hall who has lived in the village over 50 years, said that flood conditions are the worst he had ever witnessed" (Meriden Record, Mar. 13, 1936).

housatonic RIVER IN GREAT BARRINGTON, Mass. (MARCH)

"At the Great Bridge, the water is within $2 \frac{1}{2}$ feet of reaching the bridge flooring. North of the structure all previous highwater marks have been exceeded" (Berkshire Courier, Mar. 19, 1936).

HOUSATONIC RIVER AT GAYLORDSVILLE, CONN. (MARCH)

"Cornwall Bridge. Considerable damage-late hours of last Wednesday (Mar. 11) and the early hours of Thursday morning when the ice in the Housatonic River broke up causing the worst. flood ever known here" (Newtown Bee, Mar. 20, 1936).

SHEPAUG RIVER IN CONNECTICUT (MARCH)

"Ice jam just below village Mar. 12 caused inundation. Water not so high Mar. 9, 1896" (New Milford Times, Mar. 19, 1936). HOUSATONIC RIVER AT DERBY, CONN. (MARCH)

"The following are miscellaneous records of the depth of water over the dam on the Housatonic River at Derby, Conn:

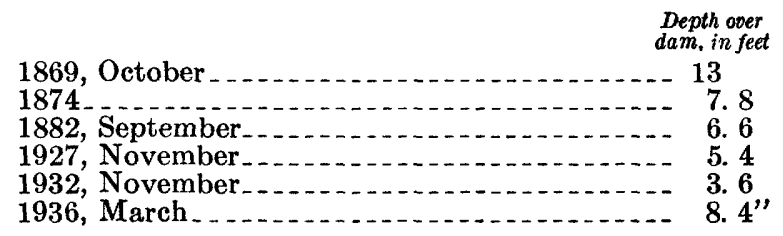

(Grover, 1937, p. 458). 
NAUGATUCK RIVER IN CONNECTICUT (MARCH)

"The river here [Ansonia] rose 17 feet during the flood. The rise was the highest in at least 25 years, according to merchants with stores over the tail race and who have kept records of the water marks in their cellars" (Ansonia Sentinel, Mar. 13, 1936). 1938

"A hurricane, an ocean storm wave, and floods combined their forces of violence in September to produce destruction of life and property probably exceeding any previous single natural disaster in the history of the nation. A tropical hurricane $* * *$ crossed Long Island and the coast of Connecticut and Rhode Island, where the gales and inundations caused almost unimaginable damage. $* * *$ The hurricane continued northward through Connecticut and Massachusetts with almost unabated force ***" (Hoyt and Langbein, 1955, p. 390,391 ).

\section{CONTOOCOOK RIVER IN NEW HAMPSHIRE (SEPTEMBER)}

Mr. G. H. Duncan, age about 80 , and former town clerk of Jaffery, N.H., was very interested in the town history which he had helped to prepare. He said that the 1938 flood was undoubtedly the biggest one that has occurred in Jaffery (oral communication, 1957).

Mr. Martin Keenan, postmaster at Peterboro, said that there was much more water in 1938 at the Peterboro Post Office than during the 1936 flood. In 1938, near the post office, the flood overtopped a wall which had been built after the 1936 flood (oral communication, 1957).

Mr. C. H. Tucker, the town clerk of Henniker, N.H., said that the 1936 flood nearly filled the arches of the stone bridge, but the 1938 flood took it out (oral communication, 1957). This stone bridge was built in 1835 (Cogswell, L. W., 1880, p. 252).

PISCATAqUOG RIVER IN NEW haMpshire (SEPTEMBER)

"April 14, 1895. Great rain. Almost unprecedented. High water in Piscataquog and Merrimack Rivers. *** Family living near the old shoeshop was compelled to vacate. House completely surrounded by water" (Hadley, 1922).

The location of the old shoeshop was pointed out by the town clerk on August 16, 1957. He stated that a whole row of houses in that vicinity were under water in 1938.

Mrs. Arthur Blood, who lives on the downstream side of the bridge just below the gaging station on the left bank, said that the 1938 flood was at least 4 feet higher than the 1936 flood and was the biggest in the 50 years that she knows about. The 1938 flood was caused in part by the failure of the Weare Dam (oral communication, 1957). 
WILLIMANTIC RIVER NEAR WILLINGTON, CONN. (SEPTEMBER)

"Wednesday morning the bridge at West Wellington was washed away ***" (Willimantic Chronicle, Sept. 26, 1938).

SHETUCKET RIVER IN CONNECTICUT (SEPTEMBER)

"In the outstanding flood of March 1876 in the Thames River basin, a dam 326 feet long on the Shetucket River at Greenville, Conn., was reported to have had 12 to 14 feet of water passing over it. A dam 401 feet long about 1200 feet downstream had water passing over it to a maximum depth of 11.1 feet on March 12,1936 , and of 14.5 feet on Sept. 21, 1938. Unless the dam in $1876 \mathrm{had}$ an extraordinarily high discharge coefficient, on the basis of these figures it appears that the peak flow of September, 1938 was the greater" (Paulsen and others, 1940, p. 553).

LITTLE RIVER NEAR HANOVER, CONN. (SEPTEMBER)

Mr. Smith, who runs the post office and store in Hanover and is one of the oldest residents, said they had never had what he'd call a bad flood on Little River. He agreed that the 1938 flood was probably the highest one and that 1936 also was real high water. He stated that the 1938 flood was about 4 feet above the old stone spillway of Hanover Dam and that the 1936 flood was about 3.5 feet above the old stone spillway (oral communication, 1957).

WILLIAMS RIVER IN VERMONT (SEPTEMBER)

For comparative flood heights at Brockway Mills, refer to oral communication by Mrs. Parkhearst, page 72.

In Chester, Vt., Mrs. Davis, town librarian, said that the water from the 1938 flood was higher in her cellar than it was during the 1927 flood (oral communication, 1957).

Mr. Hawkes, town manager, whose family have lived in Chester since about 1850, said (oral communication, 1957) that the 1938 flood was higher than the 1927 flood. Mr. L. V. Crocker, president of the National Survey, said (oral communication, 1957) that the water was 18 inches over Grafton St., during the 1927 flood; but that during the 1938 flood, the water was about 3 feet over Grafton St. These measurements were taken in front of his home.

SAXTONS RIVER AT SAXTONS RIVER, VT. (SEPTEMBER)

Mr. W. W. Hall, who has lived on the farm just across the river from the gaging station, said that the 1938 flood was the highest in 40 years and that the 1927 flood was next to the highest (oral communication, 1957).

For comparative flood information, see oral communication by Mr. A. H. Thompson, page 42. 
Mr. Joseph Rug, 86-year-old resident of Saxtons River, said that the 1869 flood was higher than the 1938 flood, which has been the highest during his life-time (oral communication, 1957).

COLD RIVER AT DREWSVILLE, N.H. (SEPTEMBER)

Mr. C. S. Newell, who owns the Alstead, Cheshire Co., a former gristmill built in 1834, said that the 1938 high water was the highest since at least 1902 and that the 1927 high water was second in magnitude (oral communication, 1957).

WEST RIVER NEAR DUMMERSTON, VT. (SEPTEMBER)

For comparative flood information, see oral communication by Charles Taft, page 42.

\section{ASHUELOT RIVER IN NEW HAMPSHIRE (SEPTEMBER)}

Mr. Leon Davis said that the 1938 flood was the highest in the vicinity of Gilsum since at least 1900 . His family, who settled there in 1873, never spoke of any other floods (oral communication, 1957).

Mr. C. F. Sumner, whose family has lived at 45 Buttler Court, Keene, since 1870 , said that the only times they had water in their cellar since 1870 were during the 1936 and 1938 floods (oral communication, 1957). Mr. Sumner is 76 years of age.

The 1938 flood was the highest flood at the Ellis Brothers and Co. greenhouses in Keene since the greenhouses were built in 1860.

For comparative flood stages at Winchester, N.H., see page 83.

Mr. Garfield, one-time official of many different mills in Hinsdale and Ashuelot, remembered the 1927, 1936, and 1938 floods, but no flood in 1920. He felt that the 1938 flood was the highest, based on his experience at an Ashuelot mill which he believed to be above any possible effects from backwater from the Connecticut River (oral communication, 1957).

otTer Broox at East sUlitvan, N.H. (SEPTEMBER)

Mrs. Goodnow and her brother, 80 and 77 years of age, respectively, knew of no floods other than that of 1938. Their family have lived in East Sullivan since 1842 (oral communication, 1957).

SOUTH BRANCH ASHUELOT RIVER IN NEW HAMPSHIRE (SEPTEMBER)

Mr. R. Ripley, president of Troy Blanket Mills, Troy, N.H., said that the 1938 flood was the highest since at least 1869 . He had two dams built in 1920 , both of which were destroyed during the 1938 flood because their spillways were too small. Other dams built in the 1800's and belonging to the mill were not bothered by the 1938 flood. Mr. Ripley believed that whoever built the old dams designed their spillways to handle the dis- 
charge from previous floods which had been forgotten by the time the dams were built in 1920 (oral communication, 1958).

SIP POND BROOK NEAR WINCHENDON, MASS. (SEPTEMBER)

Clarence and Isaac Damon, owners of the Damon Mills located about a mile above the gaging station, said that their family had lived and worked on the brook since 1832. Their home and mill are the original buildings built by their grandfather. It was their opinion, based on family legend, that there was never a flood in that vicinity which even approached the 1938 flood. Their personal knowledge goes back to before 1880 (oral communication, 1958).

MILLERS RIVER IN MASSACHUSETTS (SEPTEMBER)

Mr. W. G. Lord, author of the "History of Athol," said that the 1938 flood was the highest that he could remember (to about 1880). On the basis of the research work he had done in relation to his many articles on Athol, he felt that the 1938 flood was the highest since the town was established in 1750 (oral communication, 1957).

Mr. Starrett, president of Starrett Tools, said that his family had lived in Athol since 1870. The plant dates back 75 years, and it was never damaged by flood water before 1936 . He had never heard of a flood as great as the 1938 flood. Flood marks are painted on the side of the buildings for the 1936 and 1938 floods (oral communication, 1957).

Mr. H. Sargent of South Royalston, Mass., had done much research on the town history of Royalston. He had read of a flood in the mid-1800's which forced a store owner to place his flour up off the floor of the store. This store was still standing when Mr. Sargent read this account. However, the flood of 1938 carried away the store completely, and other structures which may have had a previous flood history. It was $\mathrm{Mr}$. Sargent's opinion that the 1938 flood was higher than any other the town ever experienced (oral communication, 1957).

NORTH RIVER IN MASSACHUSETTS (SEPTEMBER)

Mr. Gray Nickles, yard foreman of Kendall Mills, in Lyonsville, had a photograph of the outside of the old wheel pit that shows high-water marks for the 1936 and 1938 floods. The 1938 mark was about 2 feet higher than the mark for 1936 (oral communication, 1957).

For comparative flood heights, refer to oral communication by Miss B. Read, page 43.

Mr. Call, who owns Call's Garage in Colrain, Mass., said that the 1938 flood came up to the window sills on the house in which he now lives. (He bought it after the 1938 flood for \$500.) The 
1936 flood came in just over the floors of the house-about 2 feet below the 1938 flood. His ancestors moved into Colrain about 1700. His father had told him that the flood of 1869 came up into the house in which Mr. Call now lives. Mr. Call believed that the floods of 1869 and 1938 were approximately of equal magnitude (oral communication, 1957).

WARE RIVER IN MASSACHUSETTS (SEPTEMBER)

Mr. A. Tolman, the postmaster in Gilbertville, Mass., was certain that nothing as high as the 1938 flood had hit Gilbertville since 1896 (oral communication, 1957).

The 1938 Ware Town Report (the Annual Report, Water Dept. p. 8) stated: "During the flood the pumping station was flooded to a depth of 9 feet 3 inches above the main pump room floor $* * *$. The flood of 1938 exceeds all records on the Ware River and its tributaries." (Water Commissioners reports date back to 1886 when the board was first established.)

SWIFT RIVER IN MASSACHUSETTS (SEPTEMBER)

Mr. George Chuey, who is employed at Tampax, Inc., in Three Rivers, Mass., felt that he could say from talking with his parents and grandparents, who had lived in that part of the State all their lives, that the 1938 and 1955 floods were greater than any since at least 1872 (oral communication, 1957).

CHICOPEE RIVER AT INDIAN ORCHARD, MASS. (SEPTEMBer)

Mr. Walter Spaulding had a complete history of the Indian Orchard Mills. The dam, which is located right at the mill, was built in 1847. No mention was found that the river stage had ever been above the abutment of the dam before 1938. During the 1938 flood, sandbags had to be piled on top of the abutments, for the river rose 3 feet above them and would have washed out around them if the sandbags had not been used. After the 1938 flood, concrete wing walls were built on top of the abutments where the sandbags had been piled. During the 1955 flood, the stage came up to about the same height as the 1938 flood, but the wing walls proved to be adequate protection (oral communication, 1957).

WESTFIELD RIVER IN MASSACHUSETTS (SEPTEMBER)

Mr. E. Eastman, who lives in Littleville, Mass., on the Middle Branch Westfield River and whose father owned the saw mill in Littleville, said that his father pointed to a knoll on one of their hayfields as the only point in that particular field which was above water during the height of the 1878 flood. Mr. Eastman believed that there was at least a foot of water over this knoll during the 1938 and 1955 floods (oral communication, 1957). 
For comparative flood heights on the West Branch of the Westfield River in Chester, see page 73.

For comparative flood heights at Westfield, refer to oral communication by Mrs. Gagne, page 94.

STILL RIVER AT WINSTED, CONN. (SEPTEMBER)

"The worst calamity in the history of Winsted, barring none * * * water rose to an estimated depth of 6 feet in the display room of Winsted Motor Sales Co" (Winsted Citizen, Sept. 21, 1938).

WEST BRANCH FARMINGTON AT NEW HARTFORD, CONN. (SEPTEMBER)

"More disastrous than the flood of 1936 at New Hartford. For the first time known, water ran over the head of Main Street in Pine Meadow. The water was about a foot higher than during the 1936 flood" (Winsted Citizen, Sept. 22, 1938).

CONNECTICUT RIVER IN MASSACHUSETTS AND CONNECTICUT (SEPTEMBER)

For relative flood stages, refer to p. 85 .

QUINNIPIAC RIVER IN CONNECTICUT (SEPTEMBER)

"Reports around Meriden indicate that this Sept. 1938 flood exceeded all previous floods through May 1854" (Meriden Record, Sept. 22, 1938).

BLACKBERRY RIVER IN CONNECTICUT (SEPTEMBER)

"Norfolk. The worst fiood conditions in its history. *** The biggest flood since 1874" (Winsted Citizen, Sept. 22, 1938).

1953

In the Androscoggin and Saco River basins in Maine, the March 1953 flood was of major proportions.

In the Androscoggin River basin the flood of March 1953 is the greatest in respect to discharge on the Little Androscoggin River near South Paris and the Nezinscot River at Turner Center since at least 1896 and 1913, respectively, and probably since 1846 and 1820 . The flood of 1953 is the second largest known on the Androscoggin River at Auburn since at least 1850 and probably since 1785 .

In the Saco River basin the flood of March 1953 was the second largest known throughout the basin since possibly 1785. Very little damage occurred during this flood owing to the absences of severe ice jams; therefore, very little information was found pertaining to this flood.

ASSABET RIVER AT MAYNARD, MASS. (AUGUST)

Mr. William Naylor, retired superintendent of the town water department, said that the 1955 flood was the highest that he could remember (oral communication, 1957). He was 80 years old. 
Mr. J. Bengle pointed out a flood mark on the back of his house at 22 Power Mill Road for the 1955 flood and, relying on his memory, indicated points which he felt represented the heights of the 1927 and 1936 floods. For the 1927 flood he indicated a point 5 inches below the high-water mark of the 1955 flood, and for the 1936 flood he indicated a point 11 inches below the crest of the 1955 flood (oral communication, 1957).

Mr. A. Luona of 30 Power Mill Road felt that the 1955 flood was the highest since 1925 when he moved into Maynard and that the 1927 flood was the next to the highest (oral communication, 1957).

ABERJONA RIVER AT WINCHESTER, MaSS. (AUGUST)

The homes by the side of the river on Forest St. all had water in their basements during the 1955 flood, and the people who had lived there during the 1936 flood all agreed that it did not come as high as the 1955 flood.

Ruth Enstom said that she had not seen the river as high as the 1955 flood since at least 1906 when she came to live there (oral communication, 1957).

CHARLES RIVER IN MaSSACHUSETTS (AUGUST)

Mr. A. F. Howard, president of Bemis Associates, Inc., of Watertown, Mass., said he could remember no floods from 1900 to the present except the 1936, 1938, and 1955 floods. These floods were not high enough to affect his mill (oral communication, 1957).

For comparative flood heights, see oral communication by Dr. A. M. Worthington of Dedham, page 53.

NEPONSET RIVER IN MASSACHUSETTS (AUGUST)

Mr. S. A. Merrill, who has lived in Walpole for 65 years, said the only historical flood that he could remember was in 1898 . He did not think it was as great as the 1955 flood, but he did think it was higher than the 1936 flood (oral communication, 1957).

Mr. J. J. Burke, general superintendent at Bird \& Son Co., spoke of the 1898 flood. He said that the 1955 flood was the highest in recent years (oral communication, 1957).

TAUNTON RIVER IN MASSACHUSETTS (AUGUST)

"Lessening of the damage could be seen all along the Taunton River as flood waters slowly receded after climbing to one of their highest points in history" (Taunton Gazette, Aug. 24, 1955).

"Waters of Sabbatia Lake swelled to a record high after receiving flood waters from last week's storm, official figures of the Whittenton Manufacturing Co. revealed today. Highest 
mark on the measuring rod used by the firm to check waters in the lake is $\mathbf{5 7}$ inches. At its highest point after the storm, the water level climbed over that mark.

"Previous high, records showed, was after Hurricane Carol last year when the water level reached the 48-inch mark on the measuring rod. The records date back to the beginning of the firm in 1849" (Taunton Gazette, Aug. 25, 1955).

WADING RIVER IN MASSACHUSETTS (AUGUST)

Mr. Flahrety, plant superintendent of the Barrowsville Bleachery in Barrowsville, Mass., said that during August of 1955 the water over their dam was higher than at any time since 1916 (oral communication, 1957).

BLACKSTONE RIVER NEAR NORTHBRIDGE, MASS. (AUGUST)

Mr. Jeffrey Rawson, superintendent of the water department in Uxbridge, Mass., has kept a record of all the outstanding high waters since the 1927 flood. He has installed a staff gage, on the grounds of the water department on Blackstone St., Uxbridge on which the relative heights of great floods since 1927 have been painted.

The 1927 flood is the lowest, and the mark for the 1936 flood is 8 inches above the mark for the 1927 flood. The mark for the 1938 flood is 10 inches above the mark for the 1927 flood, and the mark for the August 1955 flood is 4 feet above the mark for the 1927 flood.

Mr. Rawson believed that the 1955 flood was the greatest flood since at least 1900 (oral communication, 1957).

Mr. Robert Taft, plant superintendent of Stanley Woolen Co., in Uxbridge, said that the 1955 and 1936 floods were the highest since at least 1900 (oral communication, 1957).

MUMFORD RIVER IN MASSACHUSETTS (AUGUST)

Mr. L. Brock of Whitin Machine Co., in Whitinsville, Mass., said that all their records of river stages (back to 1840) were destroyed during the 1955 flood, but he was quite sure from having talked with men who were familiar with the records, that there has never been anything like the 1955 flood since the beginning of the company in 1832 (oral communication, 1957).

Mr. Smythe, vice president of Uxbridge Worsted Co, in Uxbridge, said that, in the basement of the mill, the August 1955 flood was 5 feet higher than any other flood since at least 1900 . He believed that the 1936 flood was the next highest (oral communication, 1957).

QUABOAG RIVER IN MASSACHUSETTS (AUGUST)

Mr. E. Crossman, who lives on Route 67 on the west side of West Brimfield, Mass., and who owns a farm along the Quaboag 710-949-64-7 
River on which his father and grandfather operated a saw mill and machine shop using the waterpower, personally knew of no flood in the past 63 years and had never heard of one as high as the 1955 flood (oral communication, 1957.).

Mr. McMahon, Monson, Mass., was forced to leave his home during the 1955 flood. His mother, who was 90 years old at the time, was living with him. She had lived in Monson all her life and she could not remember anything as bad as the 1955 flood (oral communication, 1957).

MIDDLE BRANCH WESTFIELD RIVER IN MASSACHUSETTS (AUGUST)

For comparative flood heights in the vicinity of Littleville, Mass., see oral communication by Mr. E. Eastman, page 90 .

WEST BRANCH WESTFIELD RIVER IN MASSACHUSETTS (AUGUST)

Mr. Thomas Rose of Chester was a selectman of the town for many years and he wrote a brief history of Chester, Mass. He said that he did not run across any mention of floods before 1900 , while he was collecting data for his book. He believed that the 1955 flood had the most water even though the town did not suffer as much damage as in 1938. He felt that the 1938 flood was second greatest and that this was followed in magnitude by the flood of 1927, which was caused by a dam breaking in Becket, Mass. He also felt that the high water of 1933 and 1936 were about equal and that the high water of 1948 was just a little lower. Mr. Rose is quite certain that there was nothing like the floods of 1955 and 1938 back to 1885 (oral communication, 1957).

WESTFIELD RIVER IN WESTFIELD, MASS. (AUGUST)

Mrs. Gayne said that the water was 11 inches over the first floor of her house during the 1955 flood. The only other time when the water reached her home since 1920 was during the 1938 flood when there were 2 to 3 feet of water in her cellar. She was not bothered by water during either the 1927 or 1936 floods (oral communication, 1957). This same house was noted as having a full cellar during the flood of 1839 (see p. 23).

BURLINGTON BROOK IN CONNECTICUT (AUGUST)

Mr. Merton Hodge of Unionville, Conn., who lived by the third bridge above the mouth of Burlington Brook on the corner of Connecticut Highway 116 since 1908, had never seen water up to the bridge until August 1955 when there was about a foot of water over planks of bridge floor, but the bridge did not wash out (oral communication, 1957).

Mr. L. V. Barnes on the Barnes Hill Road (second bridge above mouth) said that the 1955 flood took out the bridge for 
the first time to his knowledge (about 60 years). His father was here since 1845 and had never mentioned any previous bridge being washed out. Since this was a road they used frequently, it probably would have been important enough to warrant mention (oral communication, 1957).

Pequabuck River in Connecticut (august)

"Community isolated by worst disaster in memory of residents $* * *$ the city was under attack by what old-timers termed 'the worst flood in memory'. **** For the first time in its history as a daily newspaper (since 1916) the Bristol Press was forced to suspend a scheduled publication. The flood waters submerged all motors of the newspaper press, water reaching within inches of the Bristol Press which is 4 feet above the sidewalk" (Bristol Press, Souvenir Flood Edition, Sept. 24, 1955).

Mrs. Elizabeth Tarrant, librarian at the Forestville, Conn., Library, who lived in Forestville at the time of the 1896 flood said that the 1955 flood was undoubtedly higher than the 1896 flood. In 1955, for the first time, considerable water got into the main part of Forestville and went down East Main St. at a high velocity (oral communication, 1957).

SALMON BROOK IN GRANBY, CONN. (AUGUST)

Judge Theodore Case; 80 years old, said that to his knowledge there has been no flood to equal the August 1955 flood on Salmon Brook during his lifetime (oral communication, 1957).

Mr. W. F. Messenger, the first selectman of Granby who lives in West Granby and is 73 years old, knew of no flood to equal the August 1955 flood. The March 1936 flood he remembers as being quite destructive of small wooden bridges, and the September 1938 flood as being next to the August 1955 flood in magnitude (oral communication, 1957).

HOP BROOK AT IIMSBURY, CONN. (AUGUST 2N)

"This was the worst flood in the 104 years that we have been located on Hop Brook" (Magazine of the Ensign-Bickford Co., Simsbury, Conn., p. 1).

FARMINGTON RIVER IN CONNECTICUT (AUGUST)

Mr. Rourke, owner of the old Winchell Smith grist mill in Farmington, Conn., said that a farmer of the town by the name of Dan Wall, now about 80 years old, who formerly worked in the mill for a number of years, told him that the height of the river had never approached the August 1955 level, which appears on the wall 5 feet above the second floor area, during his lifetime and that older workers when he was employed there never 
reported the river to have even approached the second floor. The mill was built around 1650 (oral communication, 1957).

Miss Alice Y. Pinney of Unionville, said the old mill presently occupied by Lawton-Miner Co., was built about 1800 . Several houses were built in the vicinity by owners and workers about the same time. The only one left now is house of L. H. Lawton, present owner of Lawton-Miner Co. It was built in 1820 by Harvey Whittlesey. The other houses of the same period were floated away by the August 1955 flood and the Whittlesey house was badly damaged, having nearly 6 feet of water over the floor. Probably the 1955 flood was greatest since 1801 or so. There was no evidence of the severity of the 1801 flood at this point (oral communication, 1957).

Mr. C. F. Woodford of Woodford's Tobacco Farm, Avon, said his house was built in 1856 by his father, who had resided nearby for several years before this. Mr. Woodford has been observing the river for more than 75 years and has seen no flood to compare with the August 1955 flood, which was about 3 feet over the living-room floor. He said that his father would not have built where he did had the 1854 flood been over the ground at the site. Apparently father and son can carry the record back prior to 1854 but not to the "Jefferson Flood" of 1801 (oral communication, 1957).

Miss B. L. Tillotson and Mr. R. Merritt, who own the Tillotson House (known as "Old Farms") on Tillotson Road ('Town Farm Road) on the Avon-Farmington town line, said that no recent floods had crossed the road in front of the house, but the August 1955 flood nearly reached the downstairs ceiling 9 feet above the floor and 8 feet above the floor in the barn. Miss Tillotson said that, according to her father, about the year 1878 water came just up to the road in front of the house and she remembers that in 1896 it came up a little further to a point in the driveway on the south side of the house (oral communication, 1957).

The 150th Anniversary Pamphlet of Town of Canton states, concerning the E. Raymond Bristol house in the road fork near east end of Town Bridge: "This place was built about 1750 by Capt. Daniel Wilcox who resided there until the 1801 flood which swept away the forge in the bend in the river [across street from the house], he losing the property by being bound by the owners of the forge." The August 1955 flood was about 5 feet above the floor in the living room, and rear ell and the porch were badly damaged. No mention was made of any serious damage in 1801.

For relative flood stages, refer to page 85 . 
BLACKBERRY RIVER IN CONNECTICUT (AUGUST)

Mr. J. R. Carroll, who runs a hardware store in Norfolk, said that prior to the 1955 flood a wooden house, built in 1756, stood about 50 feet upstream from the old stone house, built about 1824, at the foot of the hill below Norfolk on the Canaan Road [Route 44]. The wooden house was occupied and in excellent condition at the time of the August 1955 flood. The flood washed the house downstream and broke it up and also completely obliterated the cellar. The stone house is owned by Earle V. Smith, an antique dealer, and is not now occupied due to serious damage caused by the August 1955 flood. This flood is apparently the greatest since the wood house was built (1756) (oral communication, 1957).

Mrs. E. E. Burr, who is planning a History of Norfolk, said that there was a serious flood in Norfolk in 1873 or 1874 when Toby Pond dam washed out. An old house known as the Lufkin house, then occupied by her grandmother and located part way up the hill on the Canaan Road, almost washed away in 1874 and went out completely in 1955. This house went through the 1938 flood without damage (oral communication, 1957).

TENMILE RIVER IN CONNECTICUT (AUGUST)

Mr. Charles Townshend, 92 years old, lived in Webatuck, 100 yards west of the iron bridge. He had lived near here all his life. He said very emphatically that the August 1955 flood was the highest he had ever seen, but some of the flood was the result of the breakirg of the dam at Amenia Pond. The next highest flood was the September 1938 hurricane flood, which washed out the old grist-mill stoneworks at Wingdale, known as the Sheldon Mill dam (oral communication, 1957).

GHEPAUG RIVER NEAR ROXBURY, CONN. (AUGUST)

Mr. Howard Bissell, first selectman for town of Litchfield, said that his father had told him of the big flood of the 1850's, when all mills, dams, and bridges at the outlet of Bantam Lake were destroyed. He thought that from the standpoint of damage done, this was not repeated again until the flood of August 1955 (oral communication, 1957).

NAUGATUCK RIVER IN CONNECTICUT (AUGUST)

"One resident of Derby Avenue, Seymour, where houses were tossed about like toys, observed that he had, in over 70 years, never seen a drop of water in the cellar of his home.

"In spring freshet of Apr. 30, 1854, boats plied their way along Derby Avenue which was 'washed out to a depth of three feet' according to 'Seymour Past and Present' by Sharpe. The water 
on that day rose to a height of 19 feet and five inches at Seymour, which was a record until this year, when the crest was a good 25 feet above the normal bed of the river, wrecking damage previously inconceivable.

"Judge Isbell's article also mentioned that in 1857 there occurred a freshet in which 'All lower Ansonia was flooded'. But not upper Ansonia, where [in 1955] upper Main Street became indistinguishable from the Naugatuck River" (Ansonia Sentinel, Sept. 8, 1955).

\section{DATES OF FLOODS, BY STREAMS}

Stream and States

Aberjona River, Massachusetts .... February 1855; February 1886; March 1936;

August 1955.

Ammonoosuc River, New Hamp- August 1828; October 1869; November 1927. shire.

Androscoggin River, New Hamp- January 1770; October 1785; May 1814; shire, Maine.

Aroostook River, Maine October 1820; September 1826; April 1827; January 1839; April 1843; March 1846; May 1854; October 1869; April 1895; March 1896; April 1901; April 1923; November 1927; March 1936; March 1953.

Ashuelot River, New Hampshire.- September 1882; April 1895; May 1897; February 1900; March 1936; September 1938.

Assabet River, Massachusetts _- - - November 1927; March 1936; August 1955. Baker River, New Hampshire..... October 1785; February 1824; October 1869; December 1878; November 1927; March 1936.

Beaver Brook, New Hampshire _. - April 1895.

Black River, Vermont........... October 1869; November 1927.

Blackberry River, Connecticut...- November 1853; June 1869; October 1869; February 1900; March 1900; November 1927; September 1938; August 1955.

Blackstone River, Massachusetts, February 1867; March 1876; February 1886; Rhode Island. November 1927; March 1936; August 1955.

Blackwater River, New Hampshire_ August 1826; March 1936.

Branch River, Rhode Island .....- March 1876.

Burlington Brook, Connecticut.... August 1955.

Charles River, Massachusetts .... February 1807, 1818, February 1886; March 1936; September 1938; August 1955.

Chicopee River, Massachusetts.

Cocheco River, New Hampshire.--

Cold River, New Hampshire.

September 1938; August 1955.

. September 1938 .

Connecticut.

Connecticut River, New Hampshire, Vermont.

;uly or August
October 1785, March 1896. 1683; February 1692; December 1695; January 1767; January 1770 ; March 1801; January 1841; March 1843; May 1854; March 1852; April 1862; April 1869; October 1869; April 1895; March 1896; March 1913; November 1927; March 1936; September 1938; August 1955.

1770; autumn 1771; 1797; May 1818; 1828; January 1841; April 1850; April 1852; April 1862; February 1868; April 1869; October 1869; spring 1876; April 1895; 1896; March 1913; November 1927; April 1928; March 1936. 
Stream and States

Contoocook River, New Hampshire.

East Branch Housatonic River, May 1854; November 1927.

Massachusetts.

East Branch Passumpsic River, November 1927. Vermont.

Farmington River, Connecticut_-.- January 1770; February 1772; March 1801; 1804; January 1839; November 1853; May 1854; February 1857; November 1861; June 1869; October 1869; January 1874; December 1878; September 1882; March 1896; February 1900; April 1924; November 1927; March 1936; September 1938; August 1955.

Fish River, Maine

French River, Massachusetts

Furnace Brook, Connecticut Hop Brook, Connecticut.

Hop River, Connecticut

Housatonic River, Connecticut...-

Housatonic River, Massachusetts_- May 1854; October 1869; March 1896; November 1927; March 1936.

Ipswich River, Massachusetts_.... February 1886; March 1936.

Kenduskeag Stream, Maine ...... 1846; February 1870.

Kennebec River, Maine.

January 1770; March 1826; May 1832; January 1839; April 1843; April 1846; April 1852; October 1855; October 1869; February 1870; April 1887; April 1895; March 1896; December 1901; May 1923; March 1936.

Kennebunk River, Maine

October 1785; April 1827.

Little Androscoggin River, Maine... January 1839; October 1855; October 1869; February 1870; April 1895; March 1953.

Little River, Connecticut. January 1784; May 1854; February 1886; September 1938.

Machias River, Maine 1846; September 1909; May 1923.

Mad River, Connecticut_..... June 1869; March 1896; February 1900; March 1900.

Mascoma River, New Hampshire.-

Meduxnekeag River, Maine

August 1828; October 1869; March 1936.

Merrimack River, Massachusetts.-

May 1923.

December 1740; October 1785; February 1807; 1850; April 1852; March 1859; April 1862; March 1865; October 1869; April 1870; 1877; December 1878; April 1895; March 1896; 1901; 1902; November 1927; March 1936.

Merrimack River, New Hampshire_. December 1740; January 1770; 1784; October 1785; February 1807; spring 1818; April 1819; October 1820; February 1824; March 1826; August 1826; January 1839; January 1841; April 1850; April 1852; March 1859; April 1862; 1865; April 1869; October 1869; April 1870; December 1878; April 1895; March 1896; November 1927; March 1936. 


\section{Stream and States}

Middle Branch Westfield River, December 1878; September 1938; August Massachusetts.

Millers River, Massachusetts . .... April 1852; March 1936; September 1938.

Monoosnock Brook, Massachu- December 1878; February 1900; March 1900. setts.

Moose River, Vermont

Moosup River, Connecticut

Mornassuc River, Rhode Island ...

Mousam River, Maine

Muddy Brook, Connecticut......

Mumford River, Massachusetts .. -

Nashua River, Massachusetts.....-

Natchaug River, Connecticut

Naugatuck River, Connecticut....

Neponset River, Massachusetts

New England coast..............

Newfound Lake, New Hampshire..

Nezinscot River, Maine.

Nonewaug River, Connecticut

North Nashua River, Massachusetts.

North River, Massachusetts......

Ompompanoosuc River, Vermont.-

Ottauquechee River, Vermont......

Otter Brook, New Hampshire

Park River, Connecticut

Parker River, Massachusetts

Passadumkeag River, Maine

Passumpsic River, Vermont

Pawcatuck River, Rhode Island...

Pawtuxet River, Rhode Island ...-

Pemigewasset River, New Hampshire.

Penobscot River, Maine

Pequabuck River, Connecticut ... October 1869; August 1875; April 1924;

Pequonnock River, Connecticut_... July 1905.

Piscataqua River, New Hamp- January 1770; October 1785. shire, Maine.

Piscataquis River, Maine_._._.... 1832; April 1854; April 1895; May 1923.

Piscataquog River, New Hamp- 1767; January 1770; December 1784; Februshire.

Pleasant River, Maine ary 1824; August 1830; April 1862; October 1869; March 1896; September 1938.

Pomperaug River, Connecticut...- November 1853; August 1875; April 1924.

Poquonock River, Connecticut....- March 1837. 
Presumpscot River, Maine April 1827.

Quaboag River, Massachusetts...- August 1955.

Quinebaug River, Massachusetts, February 1729; February 1757; 1767; March Connecticut. 1801; 1807; 1818; March 1828; 1837; February 1867; October 1869; March 1876; February 1886; November 1927; March 1936.

Quinnipiac River, Connecticut.... February 1807; May 1854; October 1869; February 1882; January 1891; March 1896; March 1936; September 1938.

Saco River, New Hampshire, October 1775; October 1785; May 1814; Maine. October 1820; August 1826; April 1827; May 1843; April 1852; October 1869; April 1870; April 1895; March 1896; March 1936; March 1953.

St. Croix River, Maine

September 1909; May 1923.

St. John River, Maine........ Spring 1854; May 1887; May 1933.

Salmon Brook, Connecticut....-. September 1828; March 1936; September 1938; August 1955.

Salmon Falls River, New Hamp- October 1785; 1846. shire, Maine.

Sandy River, Maine............. October 1785; May 1814; October 1820; April 1827; May 1832; January 1839; October 1855; October 1869; December 1901; April 1923; March 1936.

Saxtons River, Vermont........... March 1826; October 1869; November 1927; September 1938.

Scantic River, Connecticut _. _.... 1807; October 1869.

Shepaug River, Connecticut...... November 1853; October 1869; February 1896; March 1896; March 1900; March 1936; August 1955 .

Shetucket River, Connecticut_.... February 1729; February 1757; spring 1771; February 1772; January 1784; June 1789; March 1801; February 1807; March 1823; February 1854; February 1857; February 1867; March 1876; March 1877; February 1886 ; September 1938.

Sip Pond Brook, Massachusetts... September 1938.

Sleepers River, Vermont

September 1828; April 1866; October 1869; July 1897.

Smith River, New Hampshire_....- March 1936.

Souhegan River, New Hampshire.-

August 1830; October 1869; December 1878; March 1896; March 1936.

South Branch Ashuelot River, March 1818; August 1826; September 1938. New Hampshire.

South Branch Piscataquog River, March 1936. New Hampshire.

Still River (Connecticut River November 1853; May 1854; June 1862; basin), Connecticut.

Still River (Housatonic River November 1853; May 1854; February 1869; basin), Connecticut. June 1869; January 1874; March 1896; February 1900; March 1900; April 1924; November 1927; September 1938.

October 1869; January 1874; August 1875; December 1878; January 1891; February 1896; March 1896; April 1924.

Sugar River, New Hampshire..... March 1936.

Suncook River, New Hampshire...- March 1896; March 1936.

Swift River, Maine............. October 1869; September 1938.

Swift River, Massachusetts ......- September 1938; 1955.

Taunton River, Massachusetts .... 1954; August 1955.

Ten Mile River, Connecticut.....- February 1867; September 1938; August 1955.

Thames River, Connecticut_....... January 1784.

Wading River, Massachusetts..... August 1955.

Waits River, Vermont. April 1866. 
Stream and States

Ware River, Massachusetts

Warner River, New Hampshire....

Wells River, Vermont.

\section{November 1927.} 1900; September 1938

March 1936.

September 1828; October 1869; 1876;

West Branch Farmington River, March 1936; September 1938. Connecticut.

West Branch Union River, Maine. May 1923.

West Branch Westfield River, April 1901; November 1927; March 1936; Massachusetts.

West River, Vermont.

Westfield River, Massachusetts

White River, Vermont September 1938; August 1955.

October 1869; November 1927; September 1938.

1692; January 1839; October 1869 ; December 1878; A pril 1901; November 1927; September 1938; August 1955.

Williams River, Vermont July 1830; February 1867; October 1869; November 1927.

Willimantic River, Connecticut

March 1826; October 1869; November 1927; September 1938.

Spring 1771; March 1801; October 1869; March 1877; February 1886; April 1924; March 1936; September 1938.

Winnipesaukee River, New Hamp- April 1852. shire.

Wood River, Rhode Island _....... February 1886.

Woonasquatucket River, Rhode February 1867; March 1876; February 1886. Island.

Yantic River, Connecticut
January 1784; June 1789; March 1823; February 1867; March 1876; February 1886.

\section{REFERENCES}

Atwater, Francis, about 1895, History of Southington, Connecticut: A. P. Plant and Co.

Bayles, R. M., 1889, History of Windham County, Connecticut: New York, W. W. Preston Co.

Belknap, Jeremy, 1792, The history of New Hampshire: Boston, Mass., Belknap and Young, State Street.

Bemis, C. A., 1881, History of the town of Marlboro: Boston, Mass., Press of G. H. Ellis.

Benton, E. C., 1886, History of Guildhall, Vermont: Waverly, Mass., E. C. Benton, Publisher.

Bernard, Merrill, 1941, Daily river stages at river gage stations on the principal rivers of the United States: v. 36 for the year 1938, U.S. Dept. Agriculture, Weather Bureau.

Bess, H. R., 1883, The history of Braintree, Vermont: Rutland, Vt., Tuttle and Co., State Printers.

Booker, W. E., 1940, Historical notes, Jamaica, Windham County, Vermont: Brattleboro, Vt., E. L. Hildreth Co.

Boston Society of Civil Engineers, 1930, Report of the Committee on Floods: Jour. Boston Soc. of Civil Engineers, v. 17, no. 7, Sept. 1930.

Boutin, Nathaniel, 1856, The history of Concord from its first grant in 1725 to the organization of the city government in 1853 , with a history of the ancient Penacooks: Concord, N.H., B. W. Sanborn.

Bronson, Henry, 1858, History of Waterbury, Connecticut: Waterbury, Conn., Bronson Brothers.

Brown, Abiel, 1856, Genealogical history, with short sketches and family records, of the early settlers of West Simsbury, now Canton, Connecticut, with an 
introductory and commendatory notice, by Rev. J. Burt: Hartford, Conn., Press of Case, Tiffany and Co.

Brown, D. A., 1902, The History of Penacook, New Hampshire, from its first settlement in 1734 up to 1900: Concord, N.H., Rumford Press.

Browne, G. W., 1915, Amoskeag, a history: Manchester, N.H., Amoskeag Manufacturing Co.

Burrage, H. S., 1914, The beginnings of colonial Maine, 1602-1658: Portland, Maine, Marks Printing House.

Butler, F. G., 1885, History of Farmington County, Maine, from the earliest explorations to the present time, 1776-1885: Farmington, Maine, Knowlton and McLeary Press.

Cabot, M. R., 1922, Annals of Brattleboro, 1681-1895: Brattleboro, Vt., E. L. Hildreth and Co., v. 2.

Cogswell, L. W., 1880, History of the town of Henniker, Merrimack County, New Hampshire, from the date of the Canada grant by the province of Massachusetts, 1735 to 1880 ; with a genealogical register of the families of Henniker: Concord, N.H., Republican Press Assoc.

Cole, J. R., 1888, History of Tolland County, Connecticut: New York, W. W. Preston Co.

Cooke, George, The Flood of February 1886: in the Winchester Record, v. 2 (printed for the members of the Winchester Historical and Genealogical Society and found in the Winchester, Mass., library).

Dana, H. S., 1889, History of Woodstock, Vermont: Boston and New York, Houghton, Mifflin Co.

DeLue, Willard, 1925, The story of Walpole, 1724-1924: Norwood, Mass., Ambrose Press.

Downs, C. A., 1908, History of Lebanon, New Hampshire, 1761-1887: Concord, N.H., Rumford Printing Co.

Evans, Clarence, Peter Gaylord and Gaylordsville: Lure of the Litchfield Hills, v. 8 , no. 1, June 1944 .

Fairbanks, E. T., 1912, The history of the town of St. Johnsbury, Vermonta review of one hundred twenty-five years to the anniversary pageant 1912: St. Johnsbury, Vt. Cowles Press [1914].

Federal Writers Project, 1938, New Hampshire, A guide to the Granite State: Boston, Mass. Houghton Mifflin Co.

Flood files of the Proprietors of the Locks and Canals on the Merrimack River: Lowell, Mass.

Francis, J. B., 1885, Great freshets in the Merrimac River: A paper read before the Old Residents Historical Association of Lowell, Mass., on Nov. 6, 1885, and preserved in the flood files of the Proprietors of the Locks and Canals on the Merrimac River, Lowell, Mass.

French, W. R., 1887, History of Turner [Maine], 1770-1885: Portland, Maine, Hoyt, Fogg, and Donham.

Griffin, S. G., 1904, A history of the Town of Keene from 1732-1874 (brought up to 1904 by F. H. Whitcomb): Keene, N.H., Sentinel Printing Co.

Grover, N. C., 1937, The floods of March 1936, pt. 1. New England Rivers: U.S. Geol. Survey Water-Supply Paper 798.

Hadley, G. P., 1922, History of the town of Goffstown 1733-1920: Concord, N.H., Rumford Press.

Hammond, Lawrence, 1892, Capt. Lawrence Hammond of Charlestown and Boston, his Diary, 1677-1694: Massachusetts Hist. Soc. Proc, Cambridge, Mass., J. Wilson and Son.

Hard, W. R., 1947, The Connecticut: New York, Toronto, Rhinehart \& Co., Inc. 
Harte, C. R., 1938, Connecticut Canals: New Haven, Conn., The Connecticut Co., reprinted from the 54th annual report of the Connecticut Soc. Civil Engineers.

Hayes, L. S., 1907, History of the town of Rockingham, Vermont, 1753-1907: Bellows Falls, Vt., The Town.

1927, High Water of Bellows Falls and North Walpole: Bellows Falls, Vt., P. H. Goby Press.

Hoyt, W. R., and Langbein, W. B., 1955, Floods: Princeton, N.J., Princeton Univ. Press.

Hubbard, C. H., and Dartt, Justus, 1895, History of the town of Springfield, Vermont, 1752-1895: Boston, Mass., G. H. Walker Co.

Johnson, Clifton, 1936, Hampden County, 1636-1936: New York, Am. Hist. Soc. Johnson, L. B., 1928, Vermont in floodtime: Randolph, Vt., Roy L. Johnson Co. Kinnison, H. B., 1929, The New England Flood of November, 1927: U.S. Geol. Survey Water-Supply Paper 636-C.

Kinnison, H. B., Conover, L. F., and Bigwood, B. L., 1938, Stages and flood discharge of the Connecticut River at Hartford, Connecticut: U.S. Geol. Survey Water-Supply Paper 836-A.

Lapham, W. B., and Maxim, S. P., 1884, History of Paris, Maine, from its settlement to 1880: Paris, Maine, copyrighted by Wm. B. Lapham and S. P. Maxim, 1884.

Lathrop, C. P., 1930, Black Rock, seaport of Old Fairfield, Connecticut, 16441870 (Journal of William Wheeler included): New Haven, Conn., Tuttle, Morehouse \& Taylor Co.

Lord, C. C., 1890, Life and times in Hopkinton, New Hampshire: Concord, N.H., Republican Press Assoc.

Loring, Amasa, 1880, History of Piscataquis County, Maine: Portland, Maine, Hoyt, Fogg, and Donham.

Lowell, M. C., 1935, Old Foxcroft, Maine; tradition and memories, with family records: Concord, N.H., Rumford Press.

Lyford, J. O., ed., 1896, History of Concord, New Hampshire, from the original grant in seventeen hundred and twenty-five to the opening of the twentieth century, prepared under the supervision of the City History Commisssion: Concord, N.H., Rumford Press [1903].

McKeen, Silas, 1875, A history of Bradford, Vermont, 1765-1874: Montpelier, Vt., J. D. Clark and Son.

Marriner, E. C., 1954, Kennebec yesterdays: Waterville, Maine, Colby College Press.

Marvin, A. P., 1868, History of the town of Winchendon, Worcester County, Massachusetts, from the grant of Ipswich, Canada, in 1735, to the present time: Winchendon, Mass., published by the author.

Maschin, H. F., 1955, Floods of the Westfield River Valley: an unpublished paper in the possession of H. F. Maschin, 35 South Maple St., Westfield, Mass.

Massachusetts Commission on Waterways and Public Lands, 1918, Report by the Commission on Water Resources of Massachusetts: Boston, Mass. Comm. Waterways and Public Lands.

Musgrove, R. W., 1904, History of the town of Bristol, New Hampshire: Bristol, N.H., printed by R. W. Musgrove.

Nelson, C. A. 1879, Waltham past and present, and its industries: Cambridge, Mass., T. Lewis.

Patten, Matthew, 1903, Diary of Matthew Patten, 1754-1788, of Bedford County: Concord, N.H., Rumford Printing Co. 
Paulsen, C. G., and others, 1940, Hurricane floods of September, 1938: U.S. Geol. Survey Water-Supply Paper 867.

Perley, Sidney, 1891, Historic storms of New England: Salem, Mass., Salem Press Publishing and Printing Co.

Plummer, G. F., 1930, History of the town of Wentworth, New Hampshire: Concord, N.H., Rumford Press.

Ramsdell, G. A., 1902, The history of Milford: Published by the town committee of publication, George A. Worchester, Clinton S. Averill, Concord, N.H., Rumford Press [1901].

Reichelderfer, F. W., 1955, Daily River Stages: v. 51 for the year 1955, U.S. Dept. of Commerce, Weather Bureau.

Ridlon, G. T., 1894, Saco Valley settlements and families: Portland, Maine, published by the author. [copyrighted by G: T. Ridlon, Sr., in 1894].

Runnels, M. T., 1882, 1888, History of Sanbornton, New Hampshire: Boston, Mass., A. Mudge and Son, Printers.

Sanderson, E. L., 1936, Waltham as a precinct of Watertown and as a town 1630-1884: Waltham, Mass., Waltham Historical Soc., Ine.

Sharpe, W. C., 1879, History of Seymour, Connecticut, with biographies and genealogies: Seymour, Conn., Record Print.

Smith, Albert, 1896, History of the town of Peterboro, Hillsborough County, New Hampshire: Boston, Mass., Press of G. H. Ellis.

Starr, E. C., 1936, A history of Cornwall, Connecticut, a typical New England

town: New Haven, Conn., Tuttle, Morehouse, and Taylor Co.

Tucker, W. H., 1889, History of Hartford, Vermont, July 4, 1761 to April 4, 1889: Burlington, Vt., Free Press Assoc.

U.S. Army, Corps of Engineers, 1930, Thames River in Connecticut: U.S. 71st Congress, 3d sess., Doc. 644.

1931, Merrimack River in New Hampshire and Massachusetts: U.S. 71st Congress, 3d sess., Doc. 649.

U.S. Geological Survey, 1954, Compilation of Records of surface waters of the United States through September 1950, part 1A. North Atlantic Slope basins, Maine to Connecticut: U.S. Geol. Survey Water-Supply Paper 1301.

Waite, O. F. R., 1895, History of the town of Claremont, New Hampshire, from 1764 to 1894: Manchester, N.H., John B. Clark Co.

Walker, J. B., 1896, collection of addresses and papers for various occasions: Concord, N.H.

Walter, C. T., 1928, The light and shadows of the flood of 1927: St. Johnsbury, Vt., Cowles Press.

Webster, Kimball, 1913, History of Hudson, New Hampshire: Manchester, N.H., Granite State Publishing Co.

Wells, F. P., 1902, History of Newbury, Vermont: St. Johnsbury, Vt., Caledonian Co.

Wiggin, Edward, 1922, History of Aroostook, part 1 to 1890: Presque Isle, Maine, Star-Herald Press.

Williams, F. C., 1955, Floods on the Blackstone River: A pamphlet in the Providence, R.I., Public Library.

Williamson, W. D., 1839, The history of Maine from its first discovery, A.D. 1602, to the separation, A.D. 1820, inclusive: Hallowell, Maine, Glazier, Masters and Smith.

Youngman, David, 1855, The flood at Winchester: An article written for the Woburn Journal, Feb. 21, 1855; Winchester Record, v. II, p. 184. 





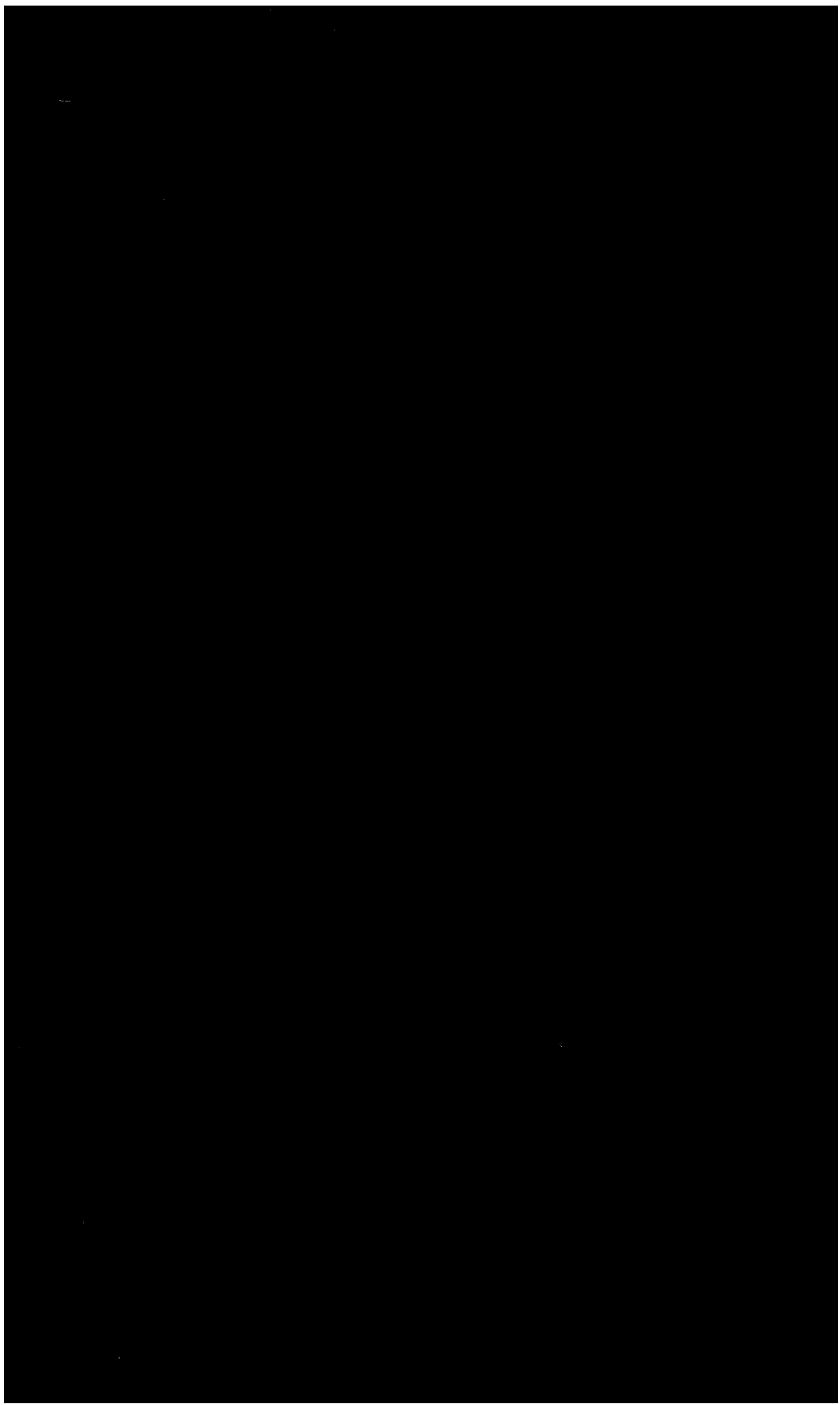




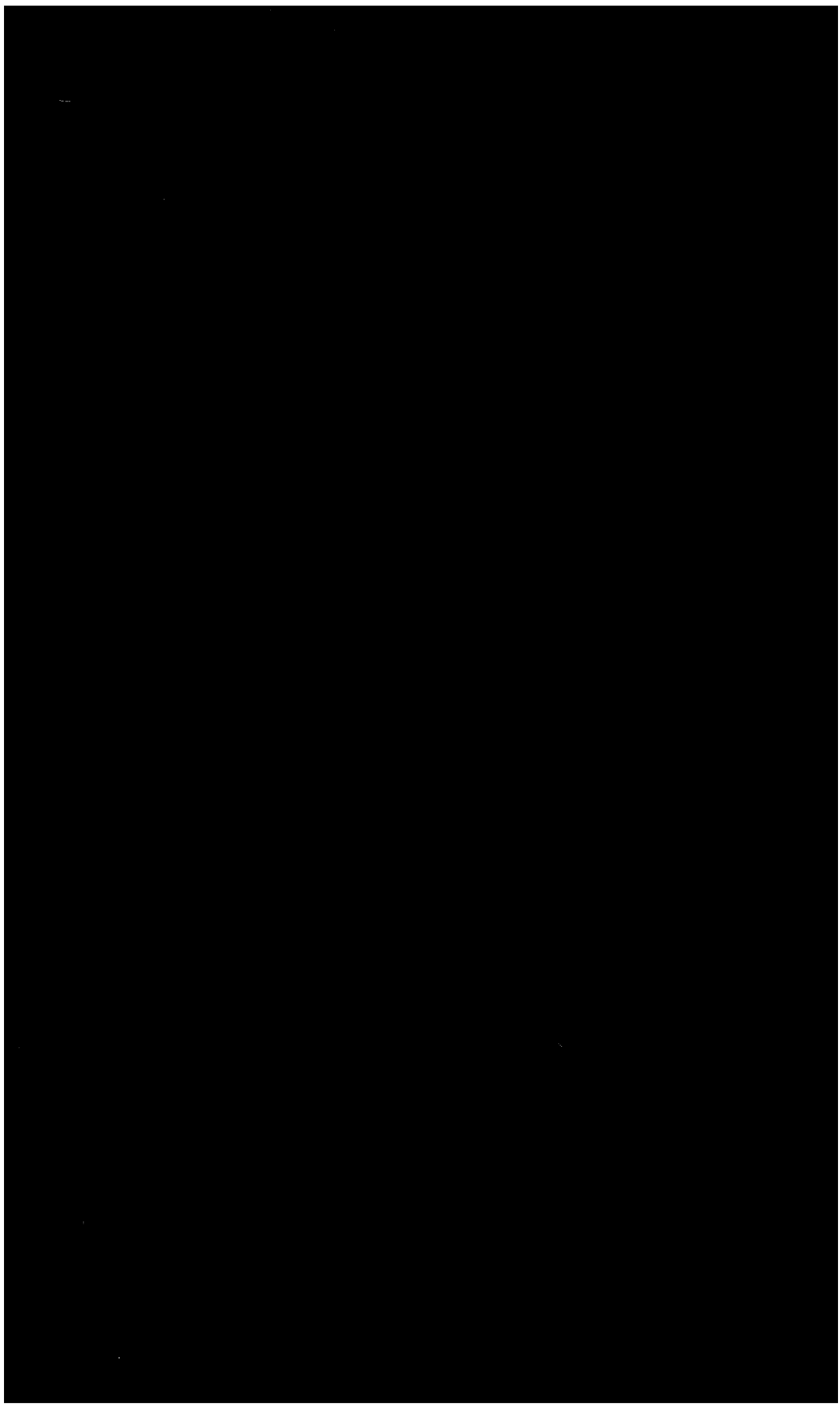

